Supporting information for:

\title{
Water-soluble BODIPY photocages with tunable cellular localization
}

\author{
Dnyaneshwar Kand," Pei Liu, $₫$ Marisol X. Navarro, ${ }^{\star}$ Logan J. Fischer, ${ }^{\diamond}$ Liat Rousso-Noori, \\ Dinorah Friedmann-Morvinski, ${ }^{\star}$ Arthur H. Winter, ${ }^{\diamond}$ Evan W. Miller,,${ }^{\dagger}{ }^{\dagger *}$ and Roy Weinstain ${ }^{\prime *}$ \\ 'School of Plant Sciences and Food Security \& `School of Neurobiology, Biochemistry and Biophysics, Faculty of \\ Life Sciences, Tel-Aviv University, Tel-Aviv 6997801, Israel; Departments of \$Chemistry and \$Molecular \& Cell \\ Biology and ${ }^{\dagger}$ Helen Wills Neuroscience Institute. University of California, Berkeley, California 94720, United \\ States; and ${ }^{\diamond}$ Department of Chemistry, Iowa State University, Ames, Iowa, 50010, United States.
}

DOI: TBD

\section{Table of Contents}

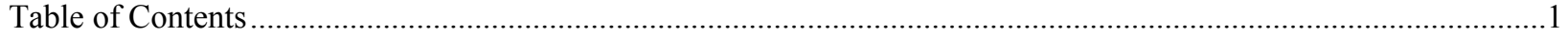

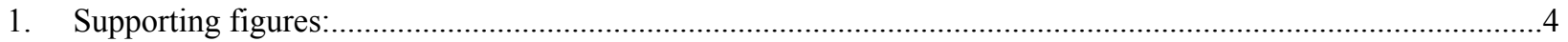

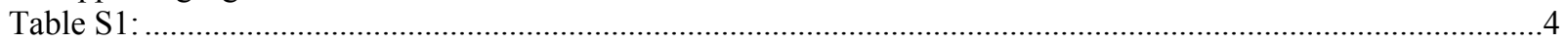

Table S2:

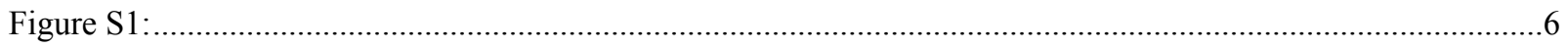

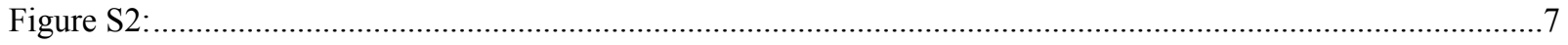

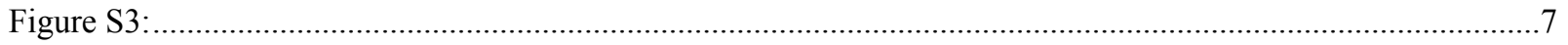

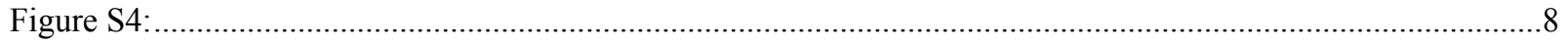

Figure S5:

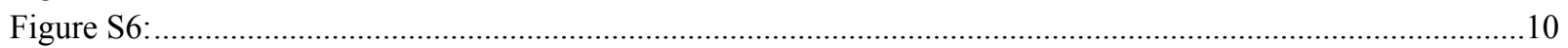

Figure S7:

Figure S8:

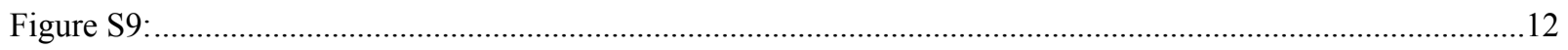

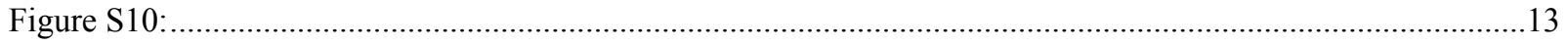

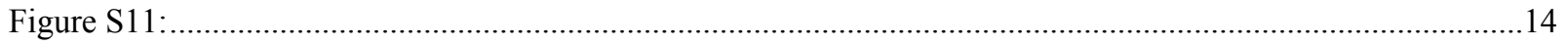

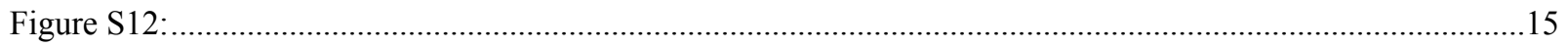

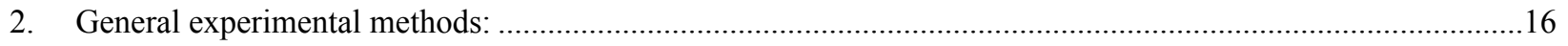

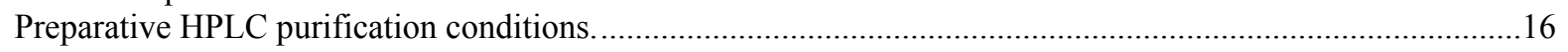

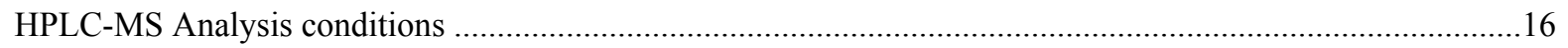

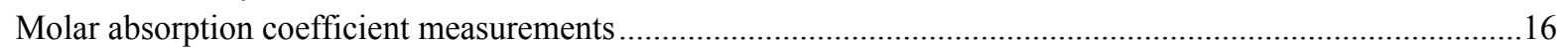

General photolysis, monitoring procedures and photolysis quantum yield calculations.....................................16

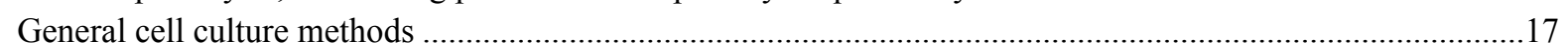

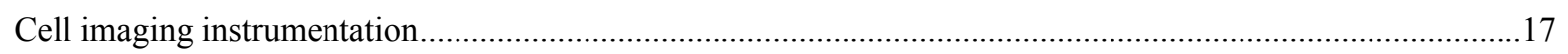

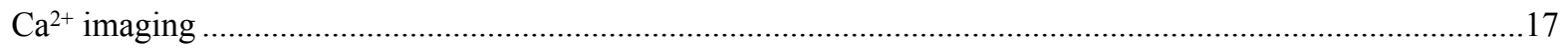

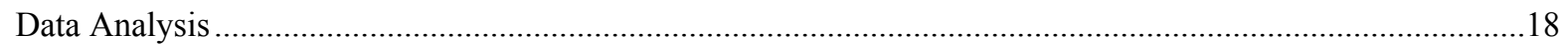

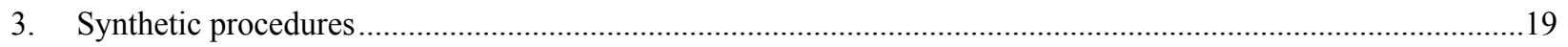

Scheme S2:

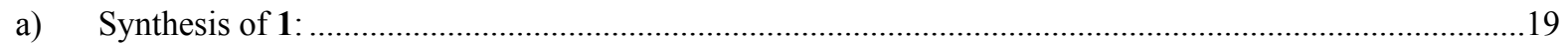

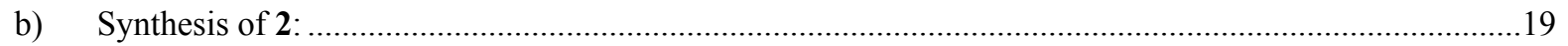

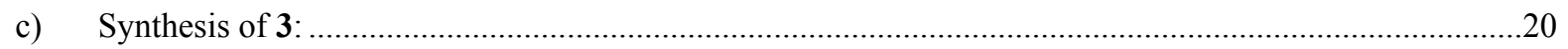

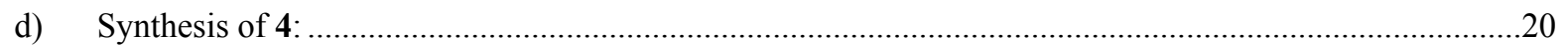

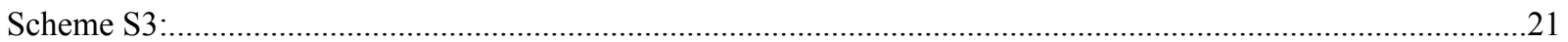




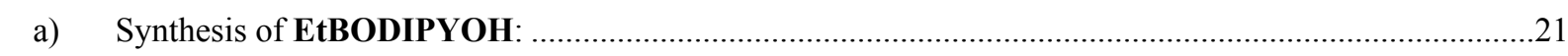

b) Synthesis of 5 :

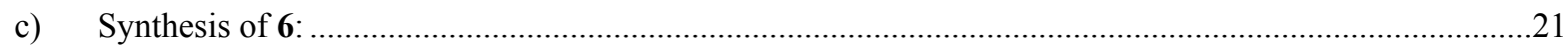

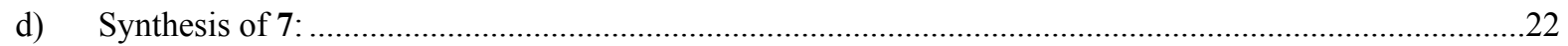

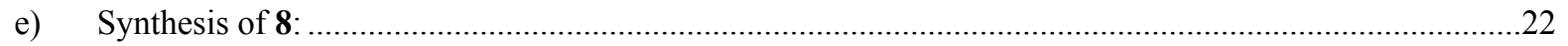

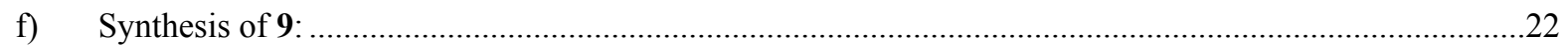

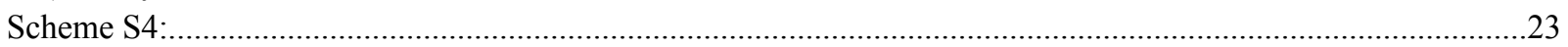

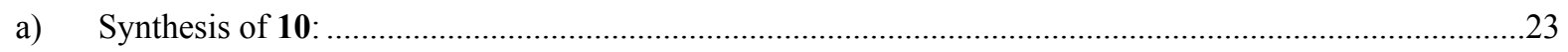

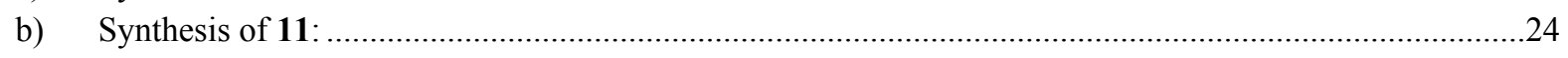

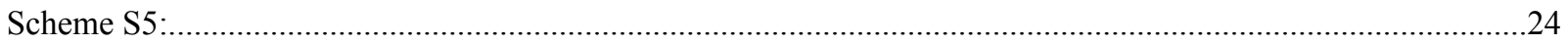

a) Synthesis of EtBODIPYPNP:

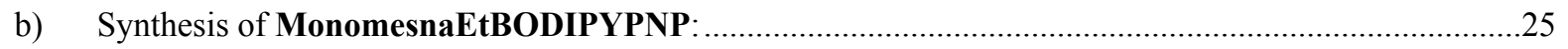

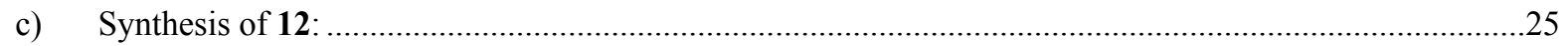

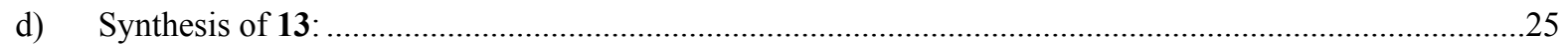

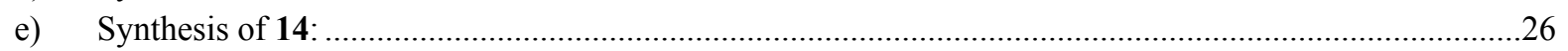

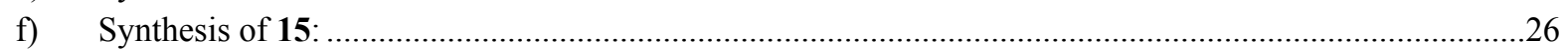

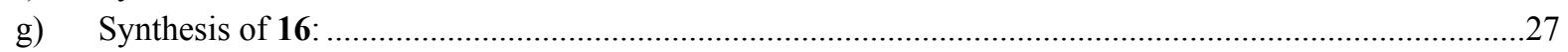

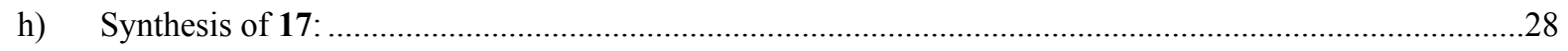

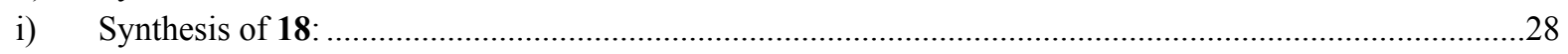

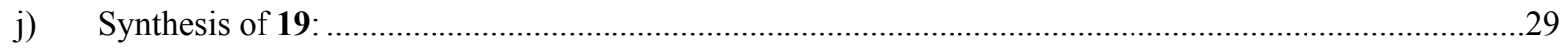

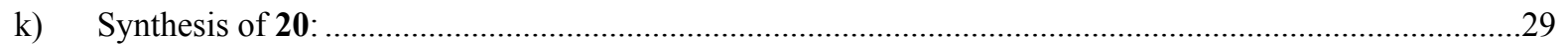

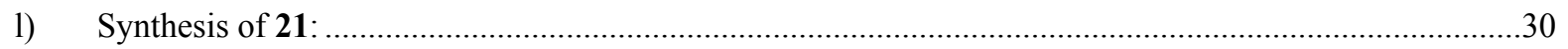

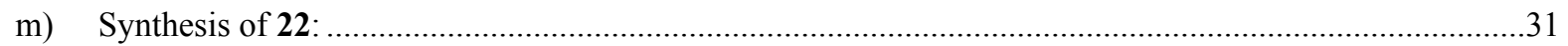

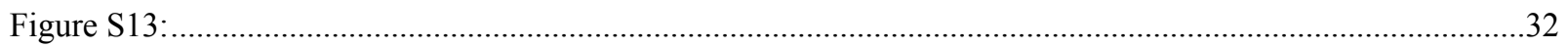

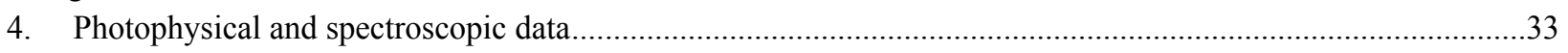

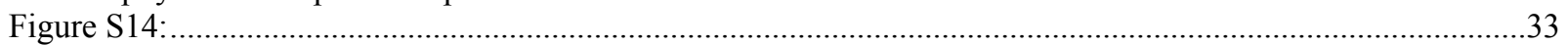

Figure S15:

Figure S16:

Figure S17:

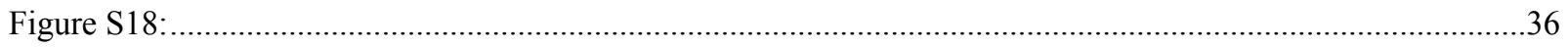

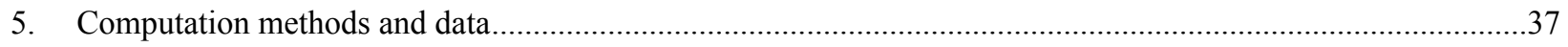

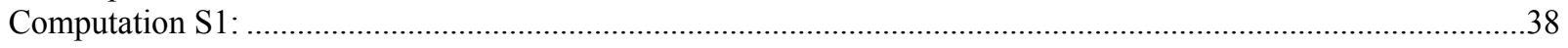

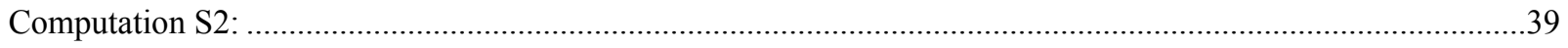

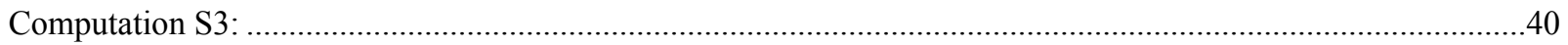

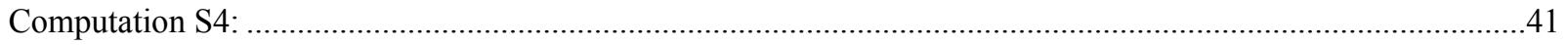

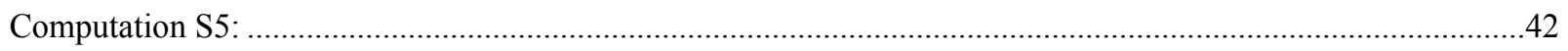

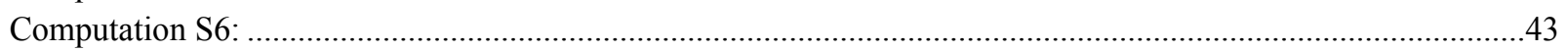

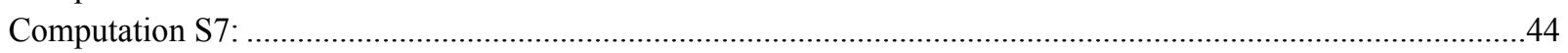

Computation S8a:

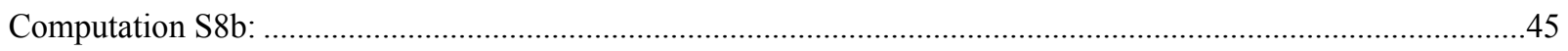

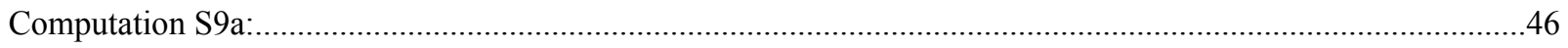

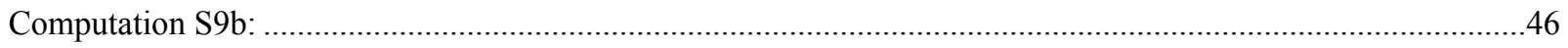

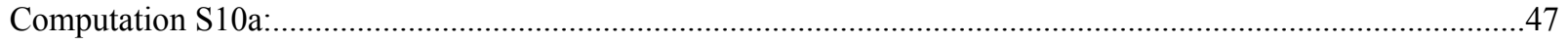

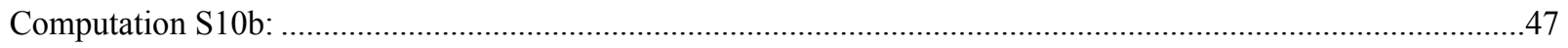

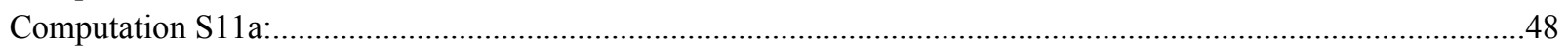

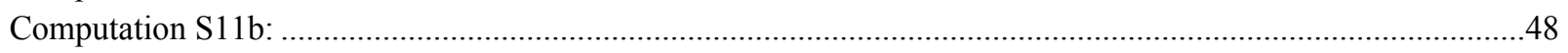

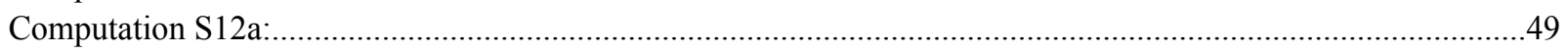

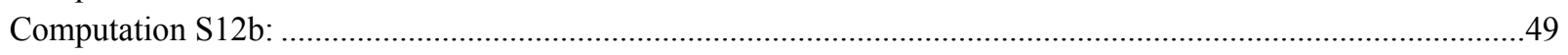

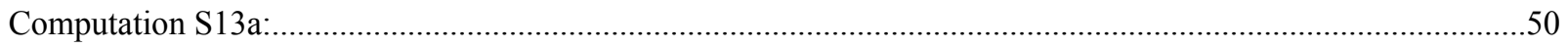


Computation S13b:

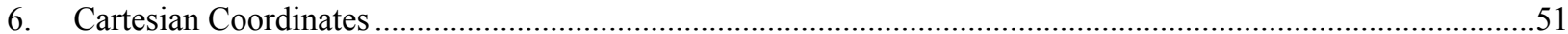

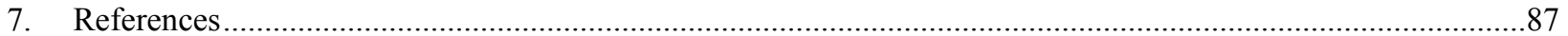

\section{Supporting figures:}

Table S1:

\begin{tabular}{|c|c|c|c|c|c|c|c|c|}
\hline Compound & $\begin{array}{l}\lambda_{\text {ex }} \\
\mathrm{nm}\end{array}$ & $\begin{array}{l}\lambda_{\mathrm{em}} \\
\mathrm{nm}\end{array}$ & $\varepsilon$ & $\Phi_{\mathrm{fl}}{ }^{\mathrm{a}}$ & $\phi_{\mathrm{rel}} \times 10^{-4}$ & $\begin{array}{l}\mathrm{T}_{1 / 2} \\
(\mathrm{~s})\end{array}$ & $\varepsilon^{*} \phi_{\text {rel }}$ & $\begin{array}{l}\text { Yield }^{\mathrm{b}} \\
(\%)\end{array}$ \\
\hline 1 & 516 & 529 & 46500 & 0.97 & 0.6 & 229.2 & 3 & 49 \\
\hline 5 & 543 & 564 & 48390 & 0.64 & 3.9 & 30.8 & 19 & 46 \\
\hline 6 & 545 & 565 & 42612 & 0.61 & NA & $\mathrm{NA}$ & NA & NA \\
\hline 7 & 545 & 559 & 43321 & 0.63 & 1.4 & 87.2 & 6 & 46 \\
\hline 8 & 552 & 565 & 50500 & 0.65 & 3.7 & 36.7 & 19 & 70 \\
\hline 9 & 560 & 574 & 45000 & 0.51 & 2.6 & 39.4 & 12 & 53 \\
\hline 10 & 550 & 570 & 47073 & 0.44 & 5.1 & 42.1 & 24 & 59 \\
\hline 11 & 560 & 577 & 48600 & 0.41 & 3.6 & 59.7 & 18 & 60 \\
\hline 16 & 549 & 567 & 43589 & 0.49 & 4.76 & 128 & 20.77 & - \\
\hline 18 & 558 & 578 & 57217 & 0.60 & 1.93 & 190 & 11.02 & - \\
\hline 21 & 542 & 561 & 43835 & 0.68 & 1.22 & 208 & 5.35 & - \\
\hline 22 & 558 & 574 & 46808 & 0.54 & 2.32 & 182 & 10.86 & - \\
\hline
\end{tabular}

Photophysical properties and photoreaction quantum yields of BODIPY derivatives in $\mathrm{CH}_{3} \mathrm{CN} /$ water $(7 / 3)$.

${ }^{a}$ Chemical yield of photolysis as quantified by spectrophotometry, NA: Not applicable.

\section{Table S2:}

Photophysical properties and photoreaction quantum yields of BODIPYs 10 and 11 in PBS and HBSS containing 1\% FBS.

$\begin{array}{llllllll}\text { Comp. } & \text { Solvent } & \lambda_{\text {ex }} & \varepsilon & \phi_{\text {rel }} \times & \mathrm{T}_{1 / 2} & \varepsilon^{*} \phi_{\text {rel }} & \text { Yield }^{\mathrm{a}}(\%) \\ & & & 10^{-4} & & \end{array}$

(s) 


\begin{tabular}{llllllll}
\hline $\mathbf{1 0}$ & PBS & 551 & 19012 & 2.5 & 60 & 4.68 & 46 \\
$\mathbf{1 1}$ & PBS & 560 & 24052 & 5.5 & 32 & 13.29 & 86 \\
$\mathbf{1 0}$ & $\begin{array}{l}\text { HBSS+ } \\
1 \% \text { FBS }\end{array}$ & 557 & 21358 & 1.02 & 144 & 2.19 & 56 \\
& $\begin{array}{l}\text { HBSS }+ \\
11\end{array}$ & 564 & 24305 & 2.6 & 90 & 6.28 & 67 \\
\hline
\end{tabular}

${ }^{a}$ Chemical yield of photolysis as quantified by spectrophotometry. 
a)

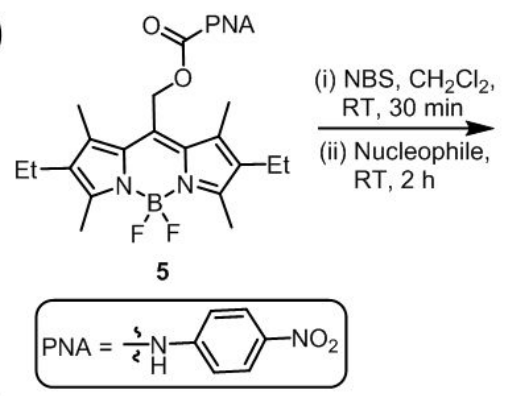

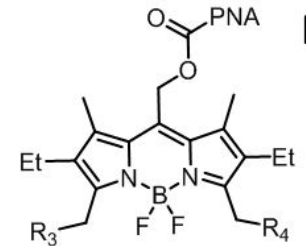

6: $\mathrm{R}_{3}=\mathrm{H}, \mathrm{R}_{4}=$ Morpholine

7: $\mathrm{R}_{3}=\mathrm{H}, \mathrm{R}_{4}=\mathrm{OEt}$

8: $\mathrm{R}_{3}=\mathrm{H}, \mathrm{R}_{4}=\mathrm{SEt}$

9: $R_{3}=R_{4}=S E t$

\begin{tabular}{|c|c|c|}
\hline Comp. & $\begin{array}{l}\text { eq. of } \\
\text { nucleophile }\end{array}$ & $\begin{array}{l}\text { Chemical } \\
\text { yield (\%) }\end{array}$ \\
\hline 6 & 38 & 68 \\
\hline 7 & 245 & 47 \\
\hline 8 & 23 & 45 \\
\hline 9 & 69 & 40 \\
\hline
\end{tabular}
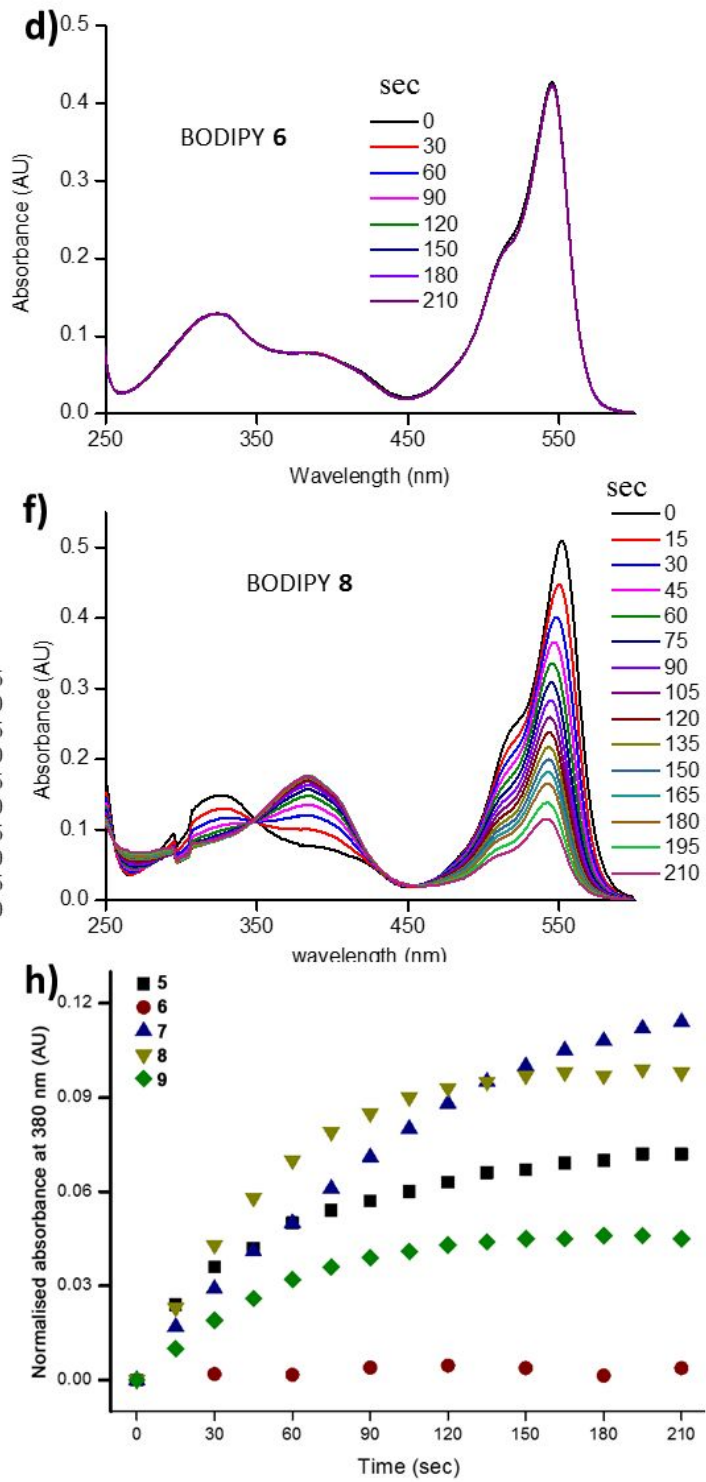

\section{Figure S1:}

(a) Synthetic scheme for BODIPYs 6-9, (b) Number of equivalents of nucleophiles and chemical yields of the optimized reactions, (c-g) UV-Vis spectra for light-induced release of PNA from BODIPYs 1 and 7-9. $10 \mu \mathrm{M}$ of each compound separately irradiated: compound 1 with 520/30 nm $\left(49 \mathrm{~mW} / \mathrm{cm}^{2}\right)$ and compounds 7-9 with 545/30 nm (49 $\mathrm{mW} / \mathrm{cm}^{2}$ ) light irradiation in $\mathrm{CH}_{3} \mathrm{CN} /$ water (7/3) for the indicated times, (h) Light-induced release of PNA from 5-9. 


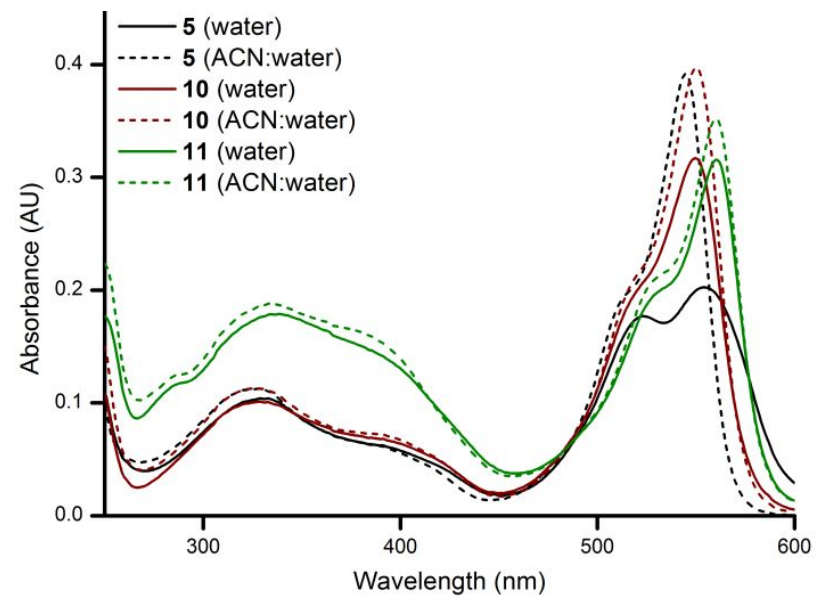

Figure S2:

Absorbance spectra of BODIPYs 5, 10 and $11\left(10 \mu \mathrm{M}\right.$ each) in $\mathrm{CH}_{3} \mathrm{CN} /$ water (7/3) (dashed line) and in water (continuous line).
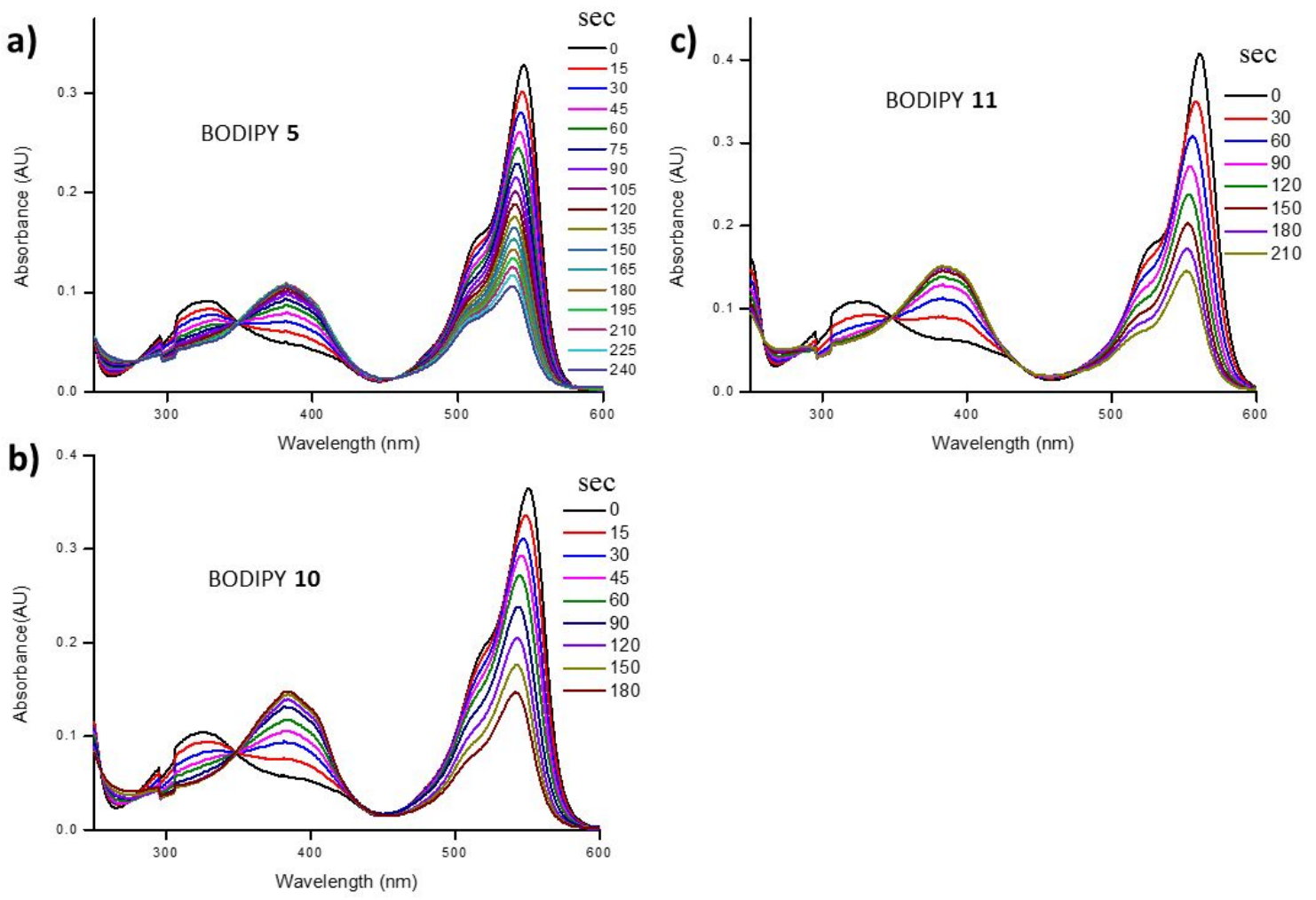

Figure S3:

(a-c) UV-Vis spectra for light-induced release of PNA from BODIPYs 5, 10 and 11. $10 \mu \mathrm{M}$ of each compound separately irradiated with $545 / 30 \mathrm{~nm}\left(49 \mathrm{~mW} / \mathrm{cm}^{2}\right)$ light in $\mathrm{CH}_{3} \mathrm{CN} /$ water $(7 / 3)$ for the indicated times. 
a)

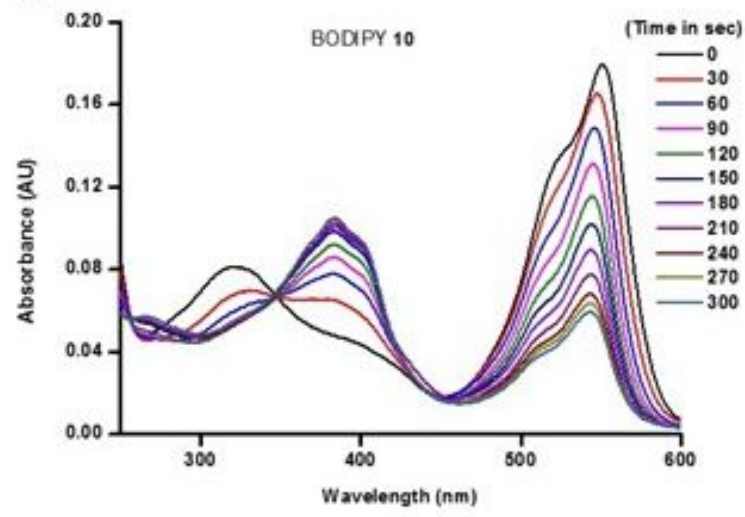

c)

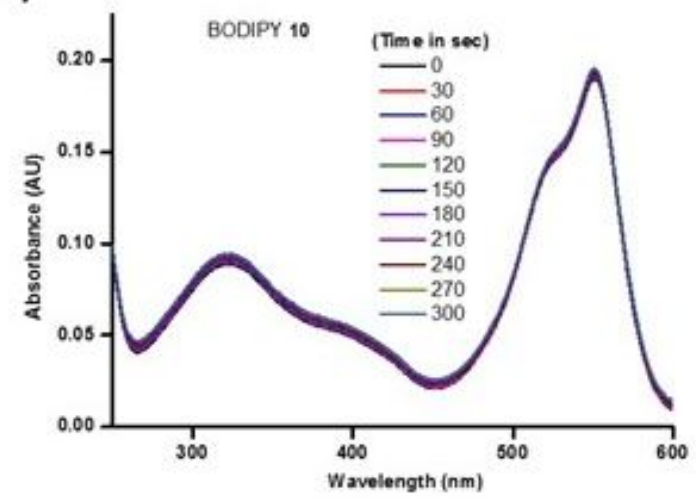

e)

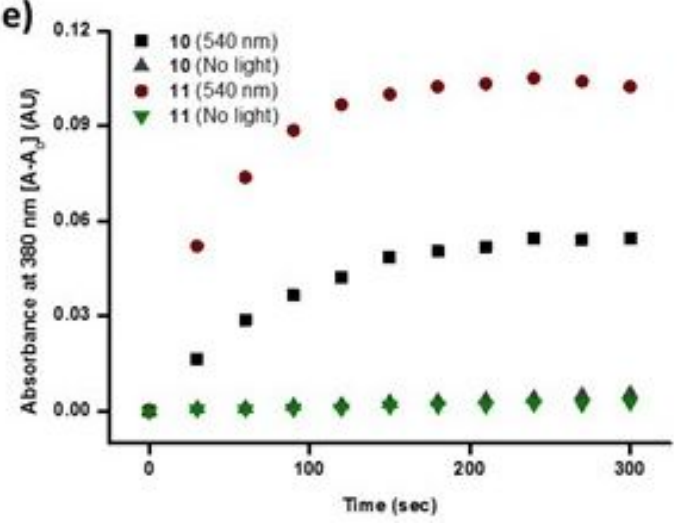

b)

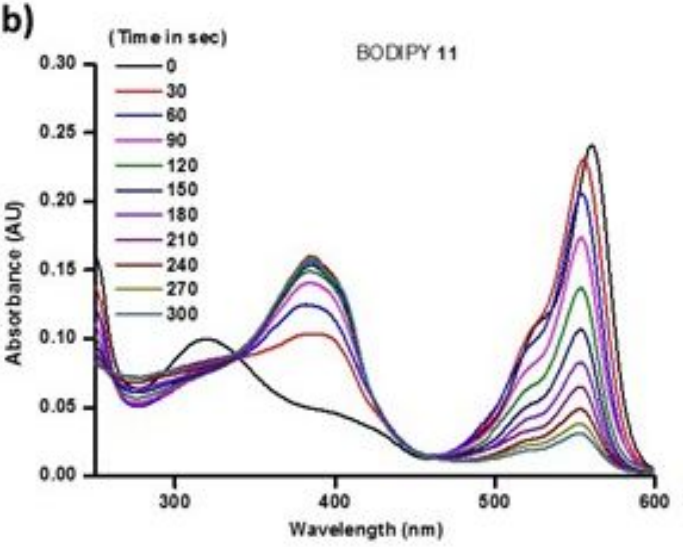

d)
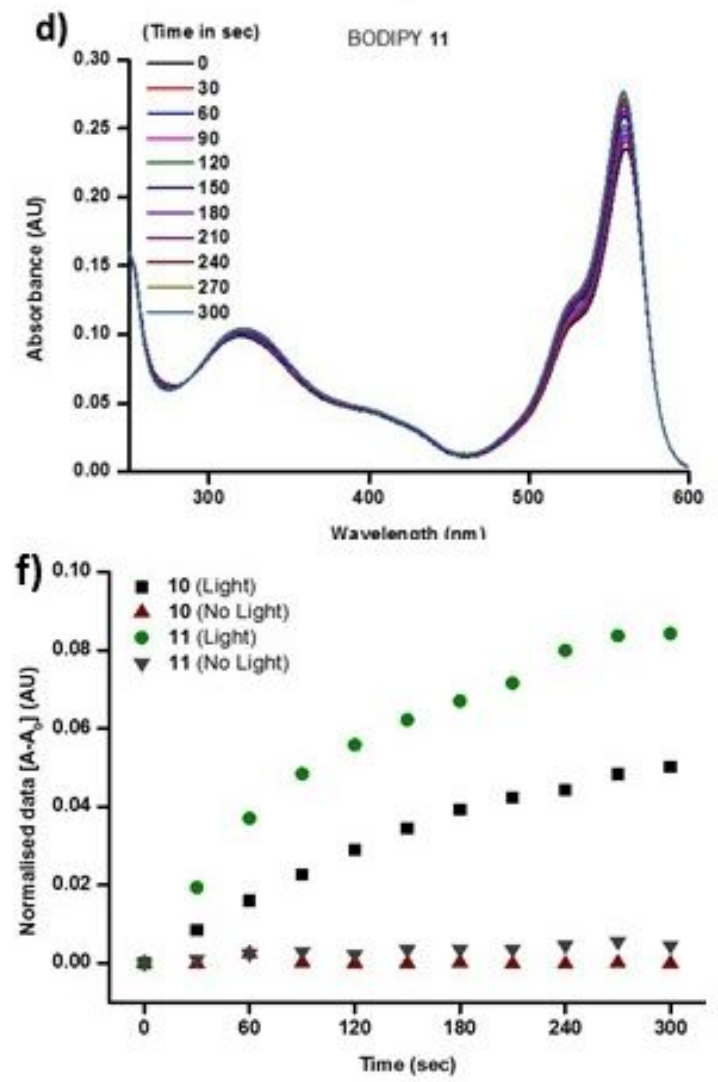

Figure S4:

(a-b) UV-Vis spectra for light-induced release of PNA from BODIPYs 10 and 11 with $\lambda_{\text {irr }}=545 / 50 \mathrm{~nm} .10 \mu \mathrm{M}$ of each compound separately irradiated with $545 / 30 \mathrm{~nm}\left(49 \mathrm{~mW} / \mathrm{cm}^{2}\right)$ light in PBS for the indicated times; (c-d) UVVis spectra of BODIPYs 10 and 11 in the absence of light; (e) PNA release in PBS either in the presence of 545/30 $\mathrm{nm}\left(49 \mathrm{~mW} / \mathrm{cm}^{2}\right)$ light or in absence of light from BODIPY photocages 10 and 11; (f) PNA release in the presence and absence of light from BODIPY photocages 10 and $11.10 \mu \mathrm{M}$ of each compound separately was either irradiated with $545 / 30 \mathrm{~nm}\left(49 \mathrm{~mW} / \mathrm{cm}^{2}\right)$ light or kept in dark in HBSS buffer containing 1\%FBS for the indicated times. 

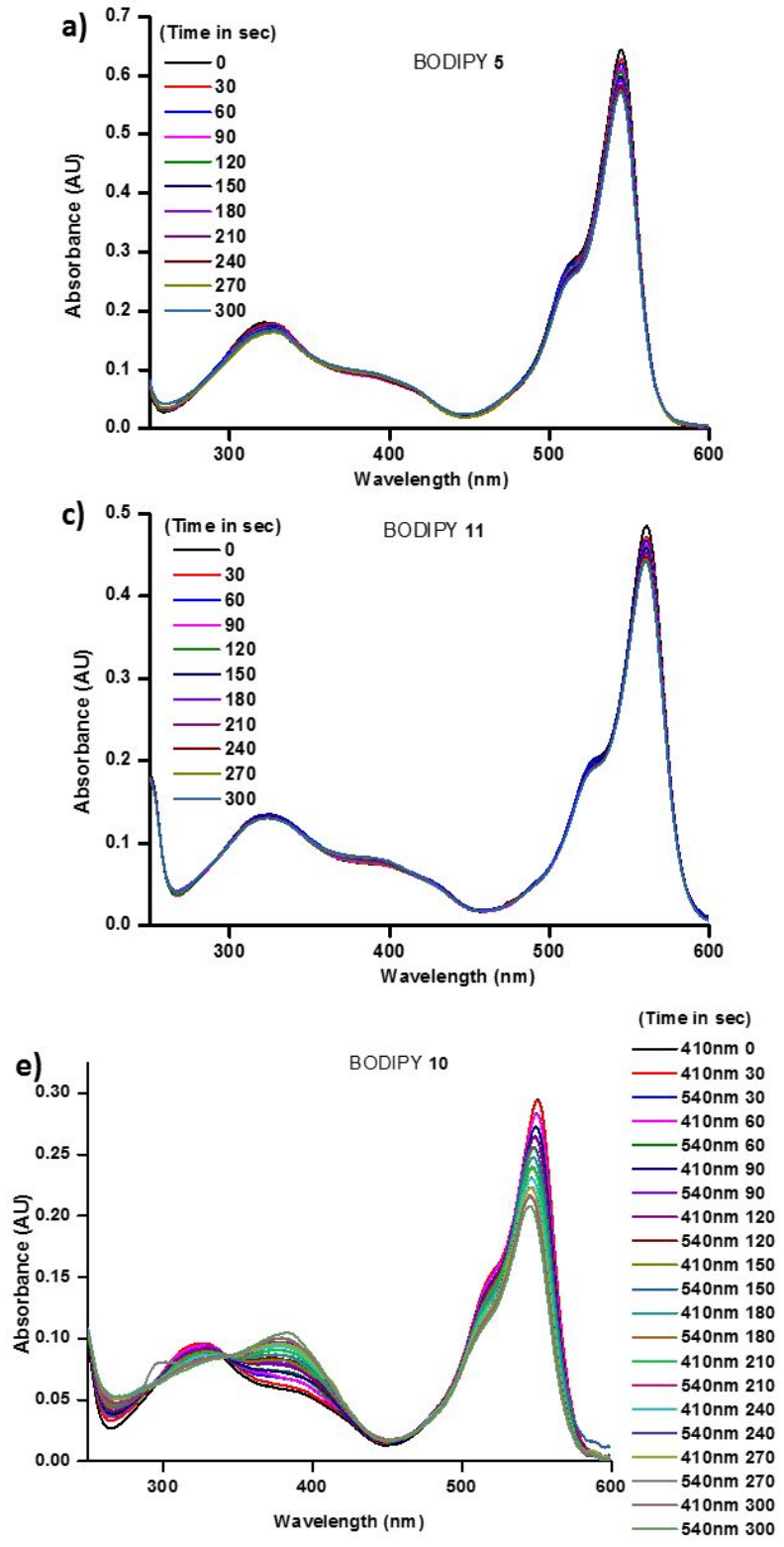
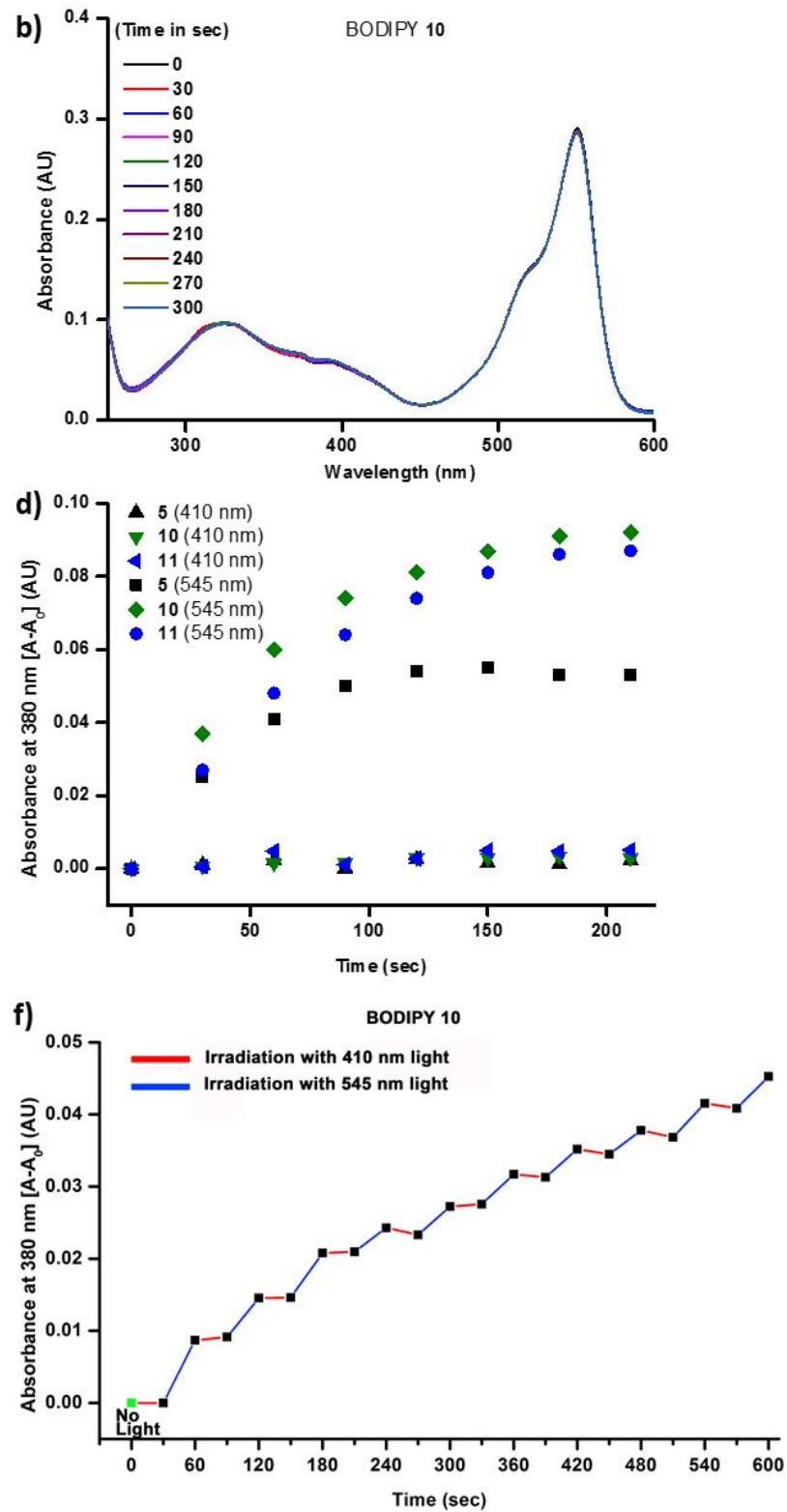

Figure S5:

(a-c) UV-Vis spectra for light-induced release of PNA from BODIPYs 5, 10 and $\mathbf{1 1}$ with $\lambda_{\text {irr }}=410 / 16 \mathrm{~nm} .10 \mu \mathrm{M}$ of each compound separately irradiated with $410 / 16 \mathrm{~nm}\left(56.2 \mathrm{~mW} / \mathrm{cm}^{2}\right)$ light in $\mathrm{CH}_{3} \mathrm{CN} /$ water (7/3); (d) PNA release in the presence of either $545 / 30 \mathrm{~nm}\left(49 \mathrm{~mW} / \mathrm{cm}^{2}\right)$ or $410 / 16 \mathrm{~nm}\left(56.2 \mathrm{~mW} / \mathrm{cm}^{2}\right)$ light from BODIPYs $\mathbf{5}, 10$ and 11; (e) UV-Vis spectra for light-induced release of PNA from BODIPY $10(10 \mu \mathrm{M})$ irradiated alternatively with 410/16 nm $\left(56.2 \mathrm{~mW} / \mathrm{cm}^{2}\right)$ light and $545 / 30 \mathrm{~nm}\left(49 \mathrm{~mW} / \mathrm{cm}^{2}\right)$ in $\mathrm{CH}_{3} \mathrm{CN} /$ water $(7 / 3)$; (f) Normalised absorbance at $380 \mathrm{~nm} V s$ time plotted from figure $\mathbf{e}$. 

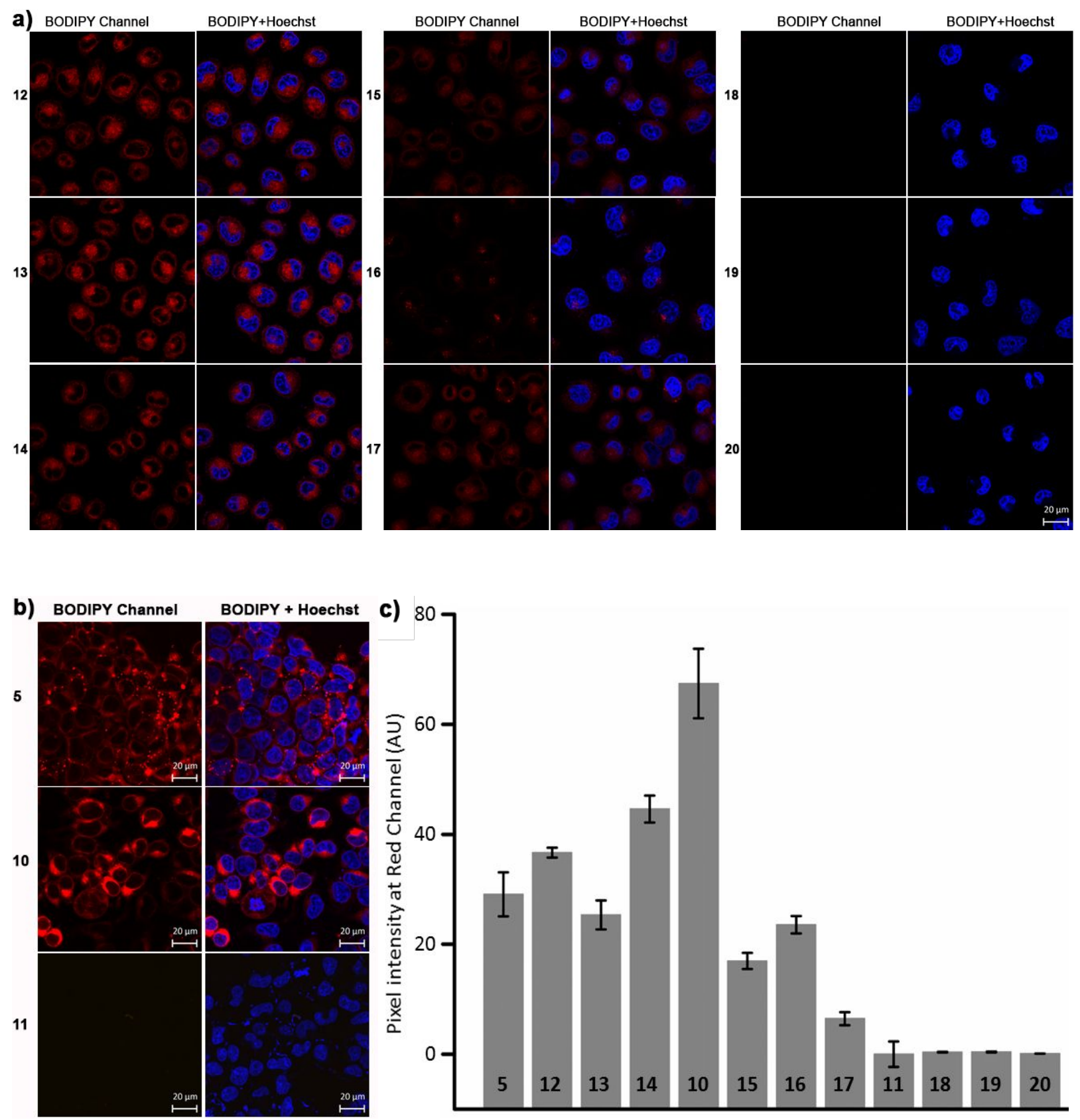

Figure S6:

Cellular permeability of BODIPYs 10-20 (a) and BODIPYs 5, 10 and $\mathbf{1 1}$ (b). HeLa cells were treated with Hoechst dye and $10 \mu \mathrm{M}$ of $\mathbf{5}$ and $\mathbf{1 0 - 2 0}$ for $30 \mathrm{~min}$, washed thrice and imaged; (c) quantification of pixel intensity at red (BODIPY) channel for selected region of interest (ROI). Six cells were selected from each image. Error bars represent standard deviation. Scale bar is $20 \mu \mathrm{m}$. 

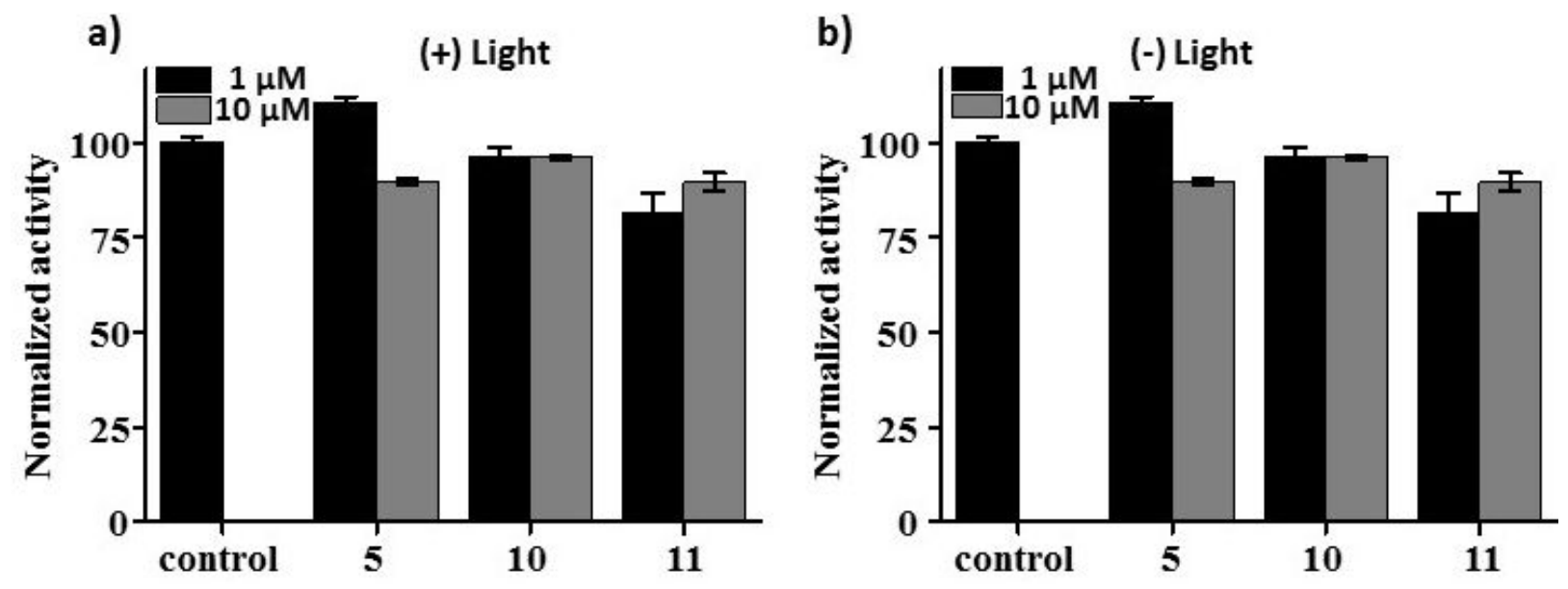

Figure S7:

WST-1 cell viability assay. HeLa cells treated with BODIPY 5, 10 and $11(1$ and $10 \mu \mathrm{M})$ were either irradiated with $545 / 30 \mathrm{~nm}\left(49 \mathrm{~mW} / \mathrm{cm}^{2}\right)$ light (a) or untreated (b) followed by incubation at $37{ }^{\circ} \mathrm{C}$ for $24 \mathrm{~h}$. Control experiments contained $0.1 \%$ DMSO. Error bars represent standard error (SE).

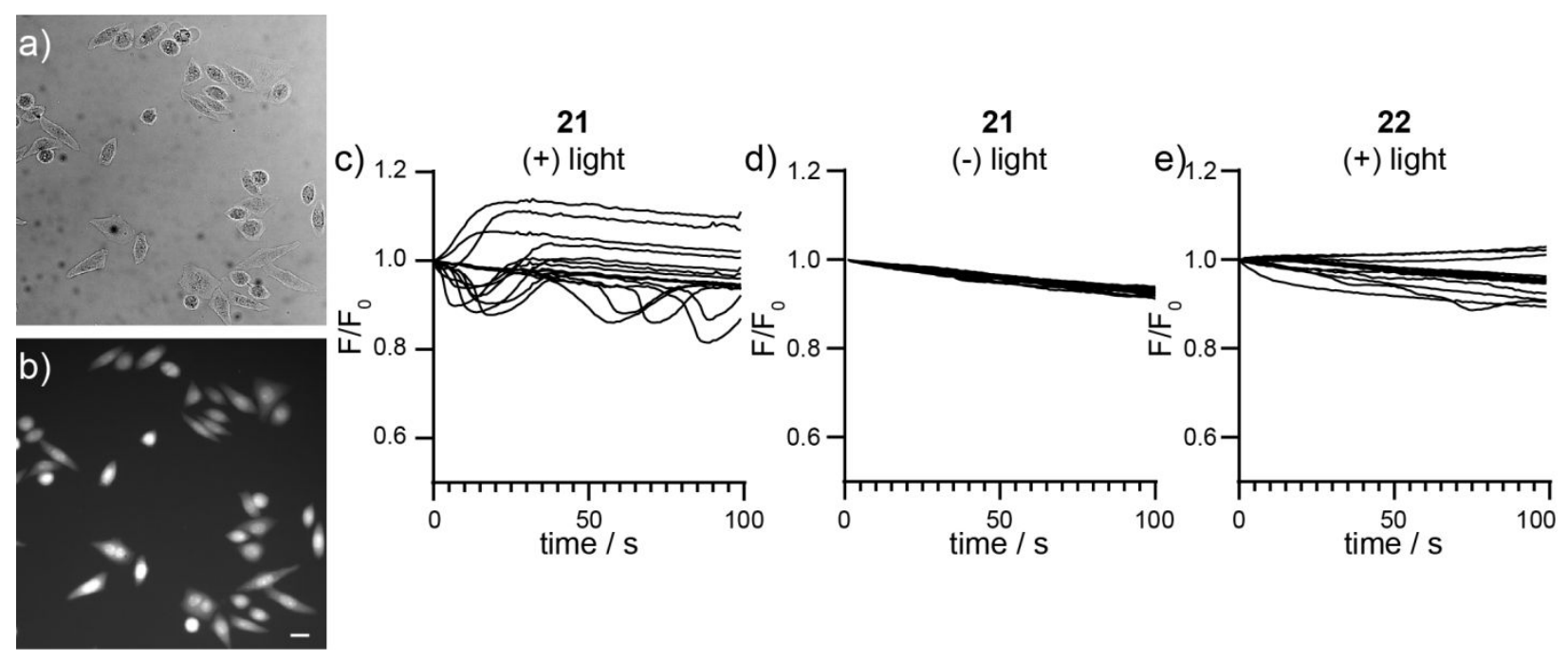

Figure S8:

Uncaging of sphingosine with BODIPY-based photocages. (a) Transmitted light and (b) widefield fluorescence image of fura- 2 associated fluorescence in HeLa cells loaded with BODIPY sphingosine 21. Scale bar is $20 \mu \mathrm{m}$. Plots of change in fura-2 fluorescence vs time for HeLa cells loaded with fura-2 $(2 \mu \mathrm{M})$ and treated with (c) BODIPY sphingosine $21+$ green light, (d) BODIPY sphingosine 21 without green light, and (e) di-MESNA-BODIPY sphingosine $22+$ green light. Both BODIPY sphingosine 21 and 22 were used at $5 \mu \mathrm{M}$. Uncaging light was provided for $10 \mathrm{~s}$ at $90 \mathrm{~mW} / \mathrm{mm}^{2}$. 

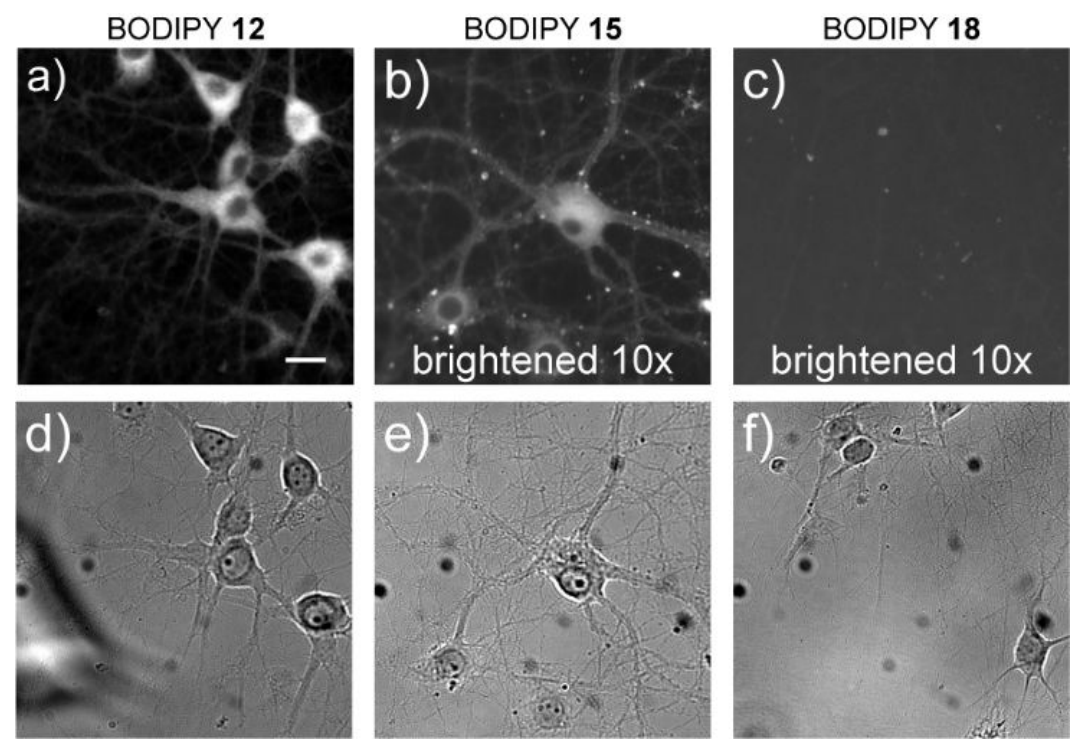

\section{Figure S9:}

MESNA-BODIPY dopamine staining in neurons. Wide-field epifluorescence microscopy (a-c) and DIC images (d-f) of cultured rat hippocampal neurons stained with a, d) BODIPY-dopamine 12, b, e) mono-MESNA BODIPYdopamine 15, or $\mathbf{c}, \mathbf{f})$ di-MESNA-BODIPY-dopamine 18. Images $b$ and $\mathrm{c}$ were brightened $10 \times$. Scale bar is $20 \mu \mathrm{m}$. 


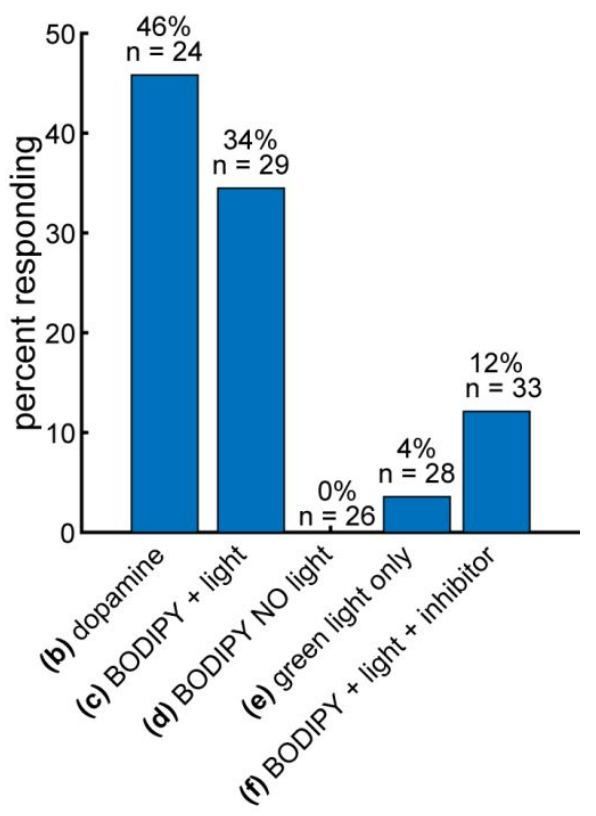

Figure S10:

Quantification of responding neurons from Figure 4. Plot depicts percentage of neurons that responded during the observation period. Neurons were treated with b) dopamine $(5 \mu \mathrm{M})$, or c) $18(5 \mu \mathrm{M})$ and uncaging light, or d) $18(5$ $\mu \mathrm{M})$ without light, or e) only with uncaging light and f) $18(5 \mu \mathrm{M})$ and light in the presence of the dopamine receptor antagonist butaclamol $(100 \mu \mathrm{M})$. Uncaging light was provided for $10 \mathrm{~s}$ at $90 \mathrm{~mW} / \mathrm{mm}^{2}$. Percentage values are included above the appropriate bars; numbers of neurons analyzed (n) are also displayed above the bars. 
a)

(+) histamine

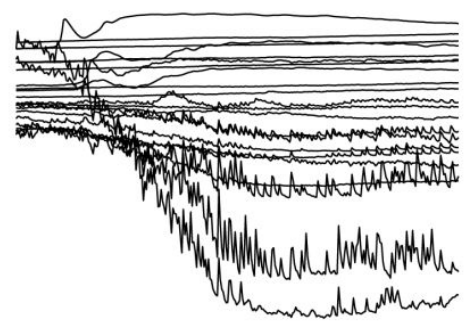

d) (+) uncaging light only

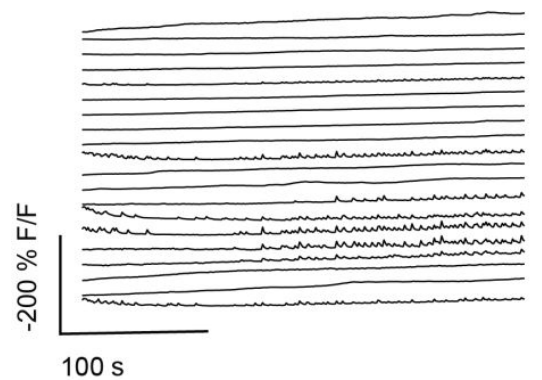

(+) mono-mesna

b) BODIPY-histamine 16

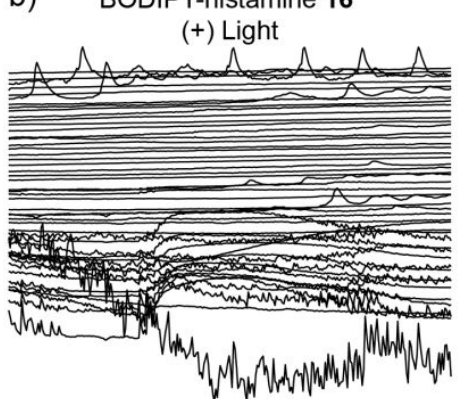

(+) mono-mesna

e) BODIPY-histamine 16

$(+)$ light $(+)$ inhibitor
(+) mono-mesna

c) BODIPY-histamine 16

(-) light

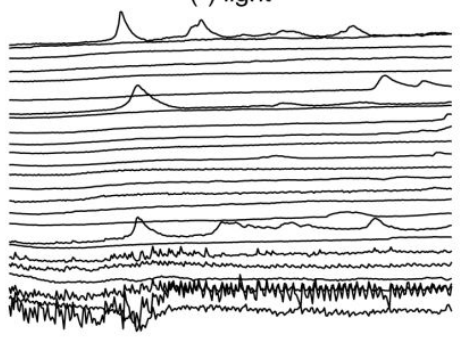

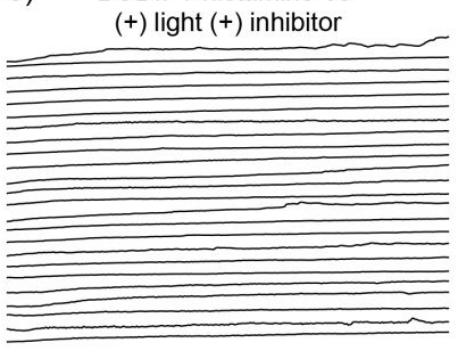

\section{Figure S11:}

Uncaging of histamine with mono-MESNA-BODIPY histamine 16 causes $\mathrm{Ca}^{2+}$ oscillations in cultured rat hippocampal neurons. $\mathrm{Ca}^{2+}$ imaging in neurons treated with (a) histamine $(5 \mu \mathrm{M})$, or (b) mono-MESNA-BODIPY histamine $16(5 \mu \mathrm{M})$ and uncaging light, or (c) $16(5 \mu \mathrm{M})$ without uncaging light, or (d) only with uncaging light, or (e) mono-MESNA-BODIPY histamine $16(5 \mu \mathrm{M})$ and uncaging light in the presence of the histamine receptor antagonist pyrilamine $(1 \mu \mathrm{M})$. Plots represent $\mathrm{F} / \mathrm{F}_{\max }$ for representative cells vs. time and are inverted. An increase in cellular $\mathrm{Ca}^{2+}$ concentration results in a decrease in fura-2 fluorescence $(2 \mu \mathrm{M})$, under the illumination conditions used in this study. Uncaging light was provided for $10 \mathrm{~s}$ at $90 \mathrm{~mW} / \mathrm{mm}^{2}$. 

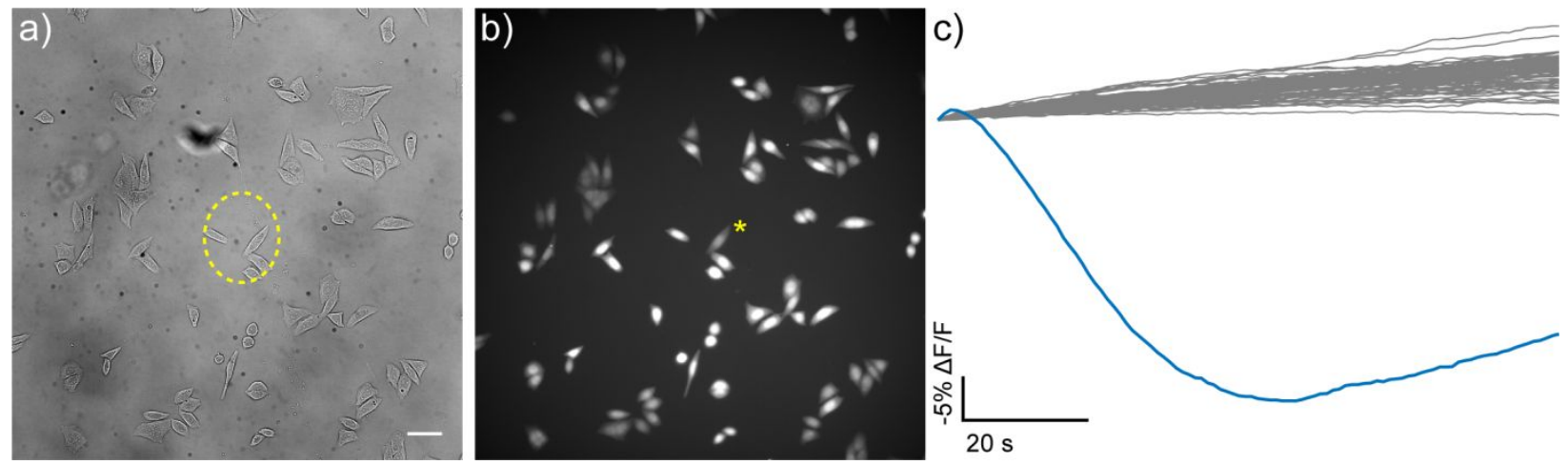

\section{Figure S12:}

Spatial control of histamine uncaging with mono-MESNA-BODIPY histamine 16 in HeLa cells. HeLa cells were loaded with fura-2 $(2 \mu \mathrm{M})$ and incubated with mono-MESNA-BODIPY histamine $16(5 \mu \mathrm{M})$. Uncaging light (542 $\mathrm{nm}, 90 \mathrm{~mW} / \mathrm{mm}^{2}, 10 \mathrm{~s}$ ) was provided over a small area (a) indicated by the yellow circle. Fluorescence from fura-2 was monitored (b). c) Plot of $\% \Delta \mathrm{F} / \mathrm{F}$ vs time for the cells in panel (b). Most cells show very little change in fura-2 associated fluorescence, while the cell with sustained change in $\mathrm{Ca}^{2+}$ concentration (indicated by yellow asterisk in panel (b)) was within the uncaging region. Scale bar is $50 \mu \mathrm{m}$. 


\section{General experimental methods:}

Pyrromethene 605 was purchased from Exciton. All other chemicals were purchased from Sigma-Aldrich and used as received unless otherwise stated. Anhydrous solvents and reagents (DCM, THF, DMSO and DMF) were obtained as SureSeal bottles from Sigma-Aldrich. Thin-layer chromatography and flash chromatography were performed using EMD pre-coated silica gel 60 F-254 plates and silica gel 60 (230-400 mesh), respectively. UV absorbance spectra were recorded on Agilent Cary 60 UV-Vis Spectrophotometer. Low resolution ESI mass spectrometry was performed on LC/MS Acquity QDa detector coupled with Waters HPLC. High resolution ESI mass spectrometry was performed on a Waters SYNAPT system. ${ }^{1} \mathrm{H}$ - and ${ }^{13} \mathrm{CNMR}$ spectra were collected in $\mathrm{CDCl}_{3}$, Acetone- $\mathrm{d}_{6}$, DMSO- $\mathrm{d}_{6}$ or $\mathrm{CD}_{3} \mathrm{OD}$ (Cambridge Isotope Laboratories, Cambridge, MA) at $25^{\circ} \mathrm{C}$ using a Bruker Advance III spectrometer at $400 \mathrm{MHz}$ and $101 \mathrm{MHz}$ respectively at the Department of Chemistry NMR Facility at Tel-Aviv University. All chemical shifts are reported in the standard $\delta$ notation of parts per million using the either TMS or residual solvent peak as an internal reference. Analytical HPLC was performed on Waters HPLC with XBridge C18 column using either Method A [water (solvent A) and acetonitrile (solvent B) with $0.1 \%$ TFA as an additive] or Method B [water (solvent A) and acetonitrile/ water: 9/1 (solvent $\mathrm{B}$ ) with $10 \mathrm{mM} \mathrm{NH} \mathrm{HCO}_{3}$ as an additive]. Abbreviations: THF: tetrahydrofuran, DMF: dimethylformamide, DCM: dichloromethane, DIPEA: diisopropylethylamine, DMAP: dimethylaminopyridine, $\mathrm{Et}_{3} \mathrm{~N}$ : trimethylamine, PNA: $p$-nitroaniline, PNP: $p$-nitrophenol, EtOAc: ethyl acetate, Hex: hexane, RT: room temperature, $\mathrm{CH}_{3} \mathrm{CN}$ : acetonitrile, TFA: trifluoroacetic acid, MESNA: 2-mercaptoethane sulfonate $\mathrm{Na}$.

\section{Preparative HPLC purification conditions.}

Preparative HPLCs was performed on Waters HPLC with XBridge C18 column with flow rate of $15 \mathrm{~mL} / \mathrm{min}$. Method A: water containing $0.1 \%$ TFA (solvent A) and acetonitrile containing $0.1 \%$ TFA (solvent B) Method B: water containing $10 \mathrm{mM} \mathrm{NH}_{4} \mathrm{HCO}_{3}$ (solvent A) and acetonitrile/Water (9/1) containing $10 \mathrm{mM} \mathrm{NH}_{4} \mathrm{HCO}_{3}$

\section{HPLC-MS Analysis conditions}

HPLC-MS analysis was performed on Waters HPLC with XBridge C18 column (100 X $3 \mathrm{~mm}, 5 \mu \mathrm{m})$ using a wateracetonitrile gradient of $0 \%$ to $100 \%$ solvent $\mathrm{B}$ in 17 minutes then 3 minutes at $100 \%$ solvent $\mathrm{B}$ at flow rate of 1 $\mathrm{mL} / \mathrm{min}$. Mass spectrometry was performed on LC/MS Acquity QDa detector coupled with Waters HPLC. Method A: water containing $0.1 \%$ TFA (solvent A) and acetonitrile containing $0.1 \%$ TFA (solvent B) Method B: water containing $10 \mathrm{mM} \mathrm{NH}_{4} \mathrm{HCO}_{3}$ (solvent A) and acetonitrile/Water (9/1) containing $10 \mathrm{mM} \mathrm{NH}_{4} \mathrm{HCO}_{3}$

\section{Molar absorption coefficient measurements}

Molar absorption coefficients $(\varepsilon)$ and maximum absorbance wavelengths $\left(\lambda_{\max }\right)$ were determined in $70 \%$ acetonitrile in water and/or 100\% acetonitrile using Beer's law, from plots of absorbance vs. concentration. Recordings were performed in $10 \mathrm{~mm}$ path length quartz cuvettes at room temperature.

\section{General photolysis, monitoring procedures and photolysis quantum yield calculations}

Compound sample ( $2 \mathrm{~mL}$ of $10 \mu \mathrm{M}$ in $70 \%$ acetonitrile in water) was placed in 10x10x30 mm quartz cuvette (10 mm path) equipped with an internal magnetic stirrer. The cuvette was placed in front of a light source (Prizmatix) with a $545 / 30 \mathrm{~nm}$ filter (Chroma) and irradiated for the indicated times while constantly stirred. Light intensity at the cuvette was measured by light meter to be $49 \mathrm{~mW} / \mathrm{cm}^{2}$ in all experiments. At each time point, samples were taken for analysis by UV-vis spectrophotometer and/or HPLC-MS. Calibration curves for all tested and reference compounds were generated in each detection method. Photolysis half-lives $\left(t_{1 / 2}\right)$ of compounds were calculated by monoexponential fitting in Origin 8.0 software. Quantum yields of photorelease were measured ${ }^{1}$ in an aerated mixture of $\mathrm{CH}_{3} \mathrm{CN} / \mathrm{water}$ 
(7/3) with compounds concentration of $10 \mu \mathrm{M}$ and $\lambda_{\text {irr }}=545 / 30 \mathrm{~nm}\left(49 \mathrm{~mW} \mathrm{~cm}^{-2}\right)$ (LED) at room temperature and under constant stirring. The optical output power of the LED at the specified peak value was measured using a calibrated optical thermal power meter (2A-BB-9, Ophir Photonics). The photoreaction was monitored to completion and the concentration of released leaving group at each time point was determined by spectrophotometry or by HPLCMS (against a standardized calibration curve of the leaving group). Only data points from the linear portion of the photoreaction progress were used for quantum yield calculation. Quantum yields values were cross validated for previously reported BODIPY derivatives..$^{2,3}$

\section{General cell culture methods}

In a glass-based dish, either 293T or HeLa cells were grown in DMEM (Biological Industries) supplemented with 10\% fetal bovine serum (Biological Industries), $2 \mathrm{mM}$ glutamine (Biological Industries), $1 \mathrm{mM}$ Sodium Pyruvate (Biological Industries), 100 units $/ \mathrm{ml}$ penicillin, and $0.1 \mathrm{mg} / \mathrm{ml}$ streptomycin. Cells were incubated in a humidified 37 ${ }^{\circ} \mathrm{C}$ incubator with $5 \% \mathrm{CO}_{2}$ (LUMITRON).

\section{Cell Viability Assay:}

HeLa cells were seeded in 96 -well plates at a density of $2 \times 10^{4}$ cells $(100 \mu \mathrm{L} \text { of culture })^{-1}$ well ${ }^{-1}$ except for the first and last columns to which only growth media was added. After a $24 \mathrm{~h}$ adhering period, the cells were either left untreated or treated with different concentrations of BODIPY 5, 10 and $\mathbf{1 1}(1$ and $10 \mu \mathrm{M})$. After a $24 \mathrm{~h}$ incubation period, the WST-1 tetrazolium salt colorimetric 19 proliferation assay was performed by adding $10 \mu \mathrm{L}$ of dissolved WST-1 solution into each well and incubating for $3 \mathrm{~h}$ at $37{ }^{\circ} \mathrm{C}$ in a $5 \% \mathrm{CO}_{2}$ incubator. The absorbance of samples was determined using a microtiter plate reader at a wavelength of $450 \mathrm{~nm}$ against a background control; the reference wavelength was $690 \mathrm{~nm}$. Each data point represents an average of 6 replicate wells.

\section{Cell imaging instrumentation}

Assessment of compound uptake by cells were imaged with a laser scanning confocal microscope (Zeiss LSM 780 inverted microscope) equipped with a 63x 1.35 Oil objective lens. BODIPY compounds were excited with $561 \mathrm{~nm}$ laser and emitted light was collected between 580 and $615 \mathrm{~nm}$. Hoechst dye was excited with $405 \mathrm{~nm}$ laser and emitted light was collected between 410 and $494 \mathrm{~nm}$.

\section{$\mathrm{Ca}^{2+}$ imaging}

Fura-2 AM was from ThermoFisher (F-1201). Imaging was performed on an AxioExaminer Z-1 (Zeiss) equipped with a Spectra-X Light engine LED light (Lumencor), controlled with Slidebook (v6, Intelligent Imaging Innovations). Images were acquired with a W-Plan-Apo 20x/1.0 water objective (20x; Zeiss) and focused onto an OrcaFlash4.0 sCMOS camera (sCMOS; Hamamatsu). Excitation for fura-2 imaging was provided at 390/22, passed through a quadruple dichroic mirror (432/38, 509/22, 586/40, 654LP), and a quadruple emission filter (430/32, 508/14, 586/30, 708/98). In this configuration, increases in $\left[\mathrm{Ca}^{2+}\right]$ result in decreases in fura-2 fluorescence. Photo-uncaging of BODIPY compounds was conducted at 542/33 nm, passing through the same dichroic and emission filter. Samples were uncaged with $542 \mathrm{~nm}$ light for $10 \mathrm{~s}$ at maximum power $\left(90 \mathrm{~mW} / \mathrm{mm}^{2}\right)$, followed by $\mathrm{Ca}^{2+}$ imaging, 50-100 $\mathrm{ms}$ exposures every second for 3 to 5 minutes after uncaging.

HeLa cells were cultured in DMEM with 10\% FBS and 5\% GlutaMax and plated on $12 \mathrm{~mm}$ round coverslips in 24 well trays at a density of $7.5 \times 10^{5}$ cells/well $12-18$ hours prior to imaging experiments. For $\mathrm{Ca}^{2+}$ imaging with caged sphingosines, BODIPY-caged sphingosine 21 or 22 was added first, at a concentration of $5 \mu \mathrm{M}$ for $10 \mathrm{~min}$ at $37^{\circ} \mathrm{C}$. After removal of the BODIPY solution, cells were rinsed 2x with Dulbecco's phosphate buffered saline (dPBS), and 
then fura-2 AM ( $2 \mu \mathrm{M}$, from a $2.5 \mathrm{mM}$ stock in 1:1 DMSO:Pluronic F-127) was added. After $20 \mathrm{~min}$ at $37{ }^{\circ} \mathrm{C}$, cells were washed $2 \mathrm{x}$ with $\mathrm{dPBS}$ and then placed into HBSS for imaging.

Neurons were harvested from rat embryonic hippocampus and cortex. All animal procedures were approved by the UC Berkeley Animal Care and Use Committees and conformed to the NIH Guide for the Care and Use and Laboratory Animals and the Public Health Policy. Hippocampi were dissected from embryonic day 19 Sprague Dawley rats (Charles River Laboratory) in cold sterile HBSS (zero $\mathrm{Ca}^{2+}$, zero $\mathrm{Mg}^{2+}$ ). All dissection products were supplied by Invitrogen, unless otherwise stated. Hippocampal tissue was treated with trypsin $(2.5 \%)$ for 15 min at $37{ }^{\circ} \mathrm{C}$. The tissue was triturated using fire polished Pasteur pipettes, in minimum essential media (MEM) supplemented with 5\% fetal bovine serum (FBS; Thermo Scientific), 2\% B-27, 2\% 1M D-glucose (Fisher Scientific) and 1\% Glutamax. The dissociated cells were plated onto $12 \mathrm{~mm}$ diameter coverslips (Fisher Scientific) pre-treated with PDL at a density of 30-35,000 cells per coverslip in MEM supplemented media (as above). Neurons were maintained at $37{ }^{\circ} \mathrm{C}$ in a humidified incubator with $5 \% \mathrm{CO}_{2}$. At 1 day in vitro (DIV) half of the MEM supplemented media was removed and replaced with Neurobasal media containing 2\% B-27 supplement and 1\% GlutaMax. Imaging was performed on mature neurons 14-18 DIV. Prior to imaging, cells were incubated with $2 \mu \mathrm{M}$ fura- $2 \mathrm{AM}$ at $37^{\circ} \mathrm{C}$ for $\sim 30 \mathrm{~min}$, washed once, and transferred to a $35 \mathrm{~mm}$ imaging dish containing $2 \mathrm{~mL}$ HBSS. BODIPY cages (for histamine and dopamine) were diluted from stocks in DMSO (1000x) to 3x concentration in $1 \mathrm{~mL}$ HBSS. This was added to the imaging dish and then the experiment began. Pyrilamine maleate $(1 \mu \mathrm{M}$, Sigma) or (+)-butaclamol (100 $\mu \mathrm{M}$, Sigma) was added prior to treatment with histamine, dopamine, or BODIPY compounds. Neurons were treated with a 3x stock of $\mathrm{KCl}$ ( $150 \mathrm{mM}$ stock, $50 \mathrm{mM}$ final) to prime the response to dopamine. After initial $\mathrm{Ca}^{2+}$ transients, as measured by fura-2 reached baseline levels, dopamine or BODIPY was added and the photolysis began.

For $\mathrm{Ca}^{2+}$ imaging in hippocampal neurons, a 25-pixel Gaussian filter was applied to each time point using ImageJ. This background was subtracted from each image in the time series before plotting. For $\mathrm{Ca}^{2+}$ imaging in $\mathrm{HeLa}$ cells, the cellular fluorescence intensity was divided by the initial intensity and plotted vs. time.

\section{Data Analysis}

Image analysis and signal quantification were done with the measurement function of ZEN lite 2012 software.

Rate constant, $k$ and Half-life of the reaction $\left(t_{1 / 2}\right)$

Rate constant, $k$ and reaction time for 50\% completion $\left(t_{1 / 2}\right)$ for each BODIPY photocage were determined according to the Equation .(S1).

$$
\mathrm{A}=a \times\left[1-\mathrm{e}^{-(k t)}\right] \quad \text { Eq. } \mathrm{S} 1
$$

Where, $\mathrm{A}=$ absorbance at $380 \mathrm{~nm}, a=$ arbitrary constant, $k=$ pseudo first order rate constant, $t=$ time.

Half-life of the reaction $\left(t_{1 / 2}\right)$ was calculated using Equation (S2)

$$
t_{1 / 2}=0.693 / k
$$

Where $k=$ pseudo first order rate constant. 


\section{Synthetic procedures}

\section{Scheme S2:}

Synthetic scheme for $\mathbf{2}$ and $\mathbf{3}$ :

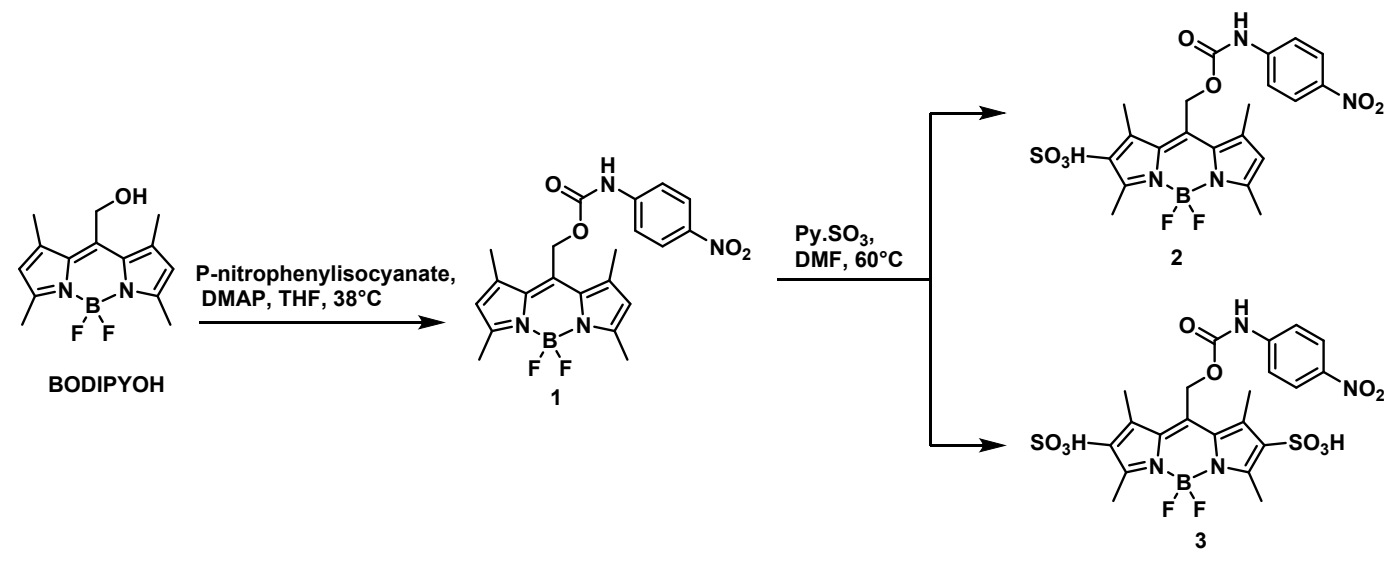

a) Synthesis of $\mathbf{1}$ :

To a stirred solution of BODIPYOH $(100 \mathrm{mg}, 0.36 \mathrm{mmol})$ in toluene $(5.0 \mathrm{~mL})$ at room temperature under argon

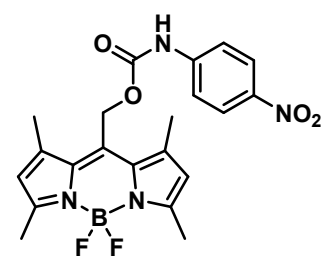
atmosphere, $p$-nitrophenylisocyanate $(236 \mathrm{mg}, 1.44 \mathrm{mmol})$ and $\mathrm{Et}_{3} \mathrm{~N}(150 \mu \mathrm{L}, 1.08 \mathrm{mmol})$ were added. The reaction mixture was stirred for $5 \mathrm{~h}$ at that temperature. After full conversion of starting material (TLC, mobile phase $20 \%$ EtOAc in n-Hexanes), the reaction was diluted with EtOAc $(20.0 \mathrm{~mL})$ and washed with saturated $\mathrm{NH}_{4} \mathrm{Cl}$ solution $(10.0 \mathrm{~mL})$ and brine $(10.0$ $\mathrm{mL})$. The water fractions were extracted with EtOAc $(10.0 \mathrm{~mL} \mathrm{X} \mathrm{2).} \mathrm{The} \mathrm{combined} \mathrm{organic}$ phase was dried with $\mathrm{MgSO}_{4}$, filtered and solvents were removed under reduced pressure. The crude mixture was purified by silica gel chromatography $(0-12 \%$ EtOAc in n-Hexane gradient) to yield $1(65 \mathrm{mg}, 41 \%)$ as an orange solid. ${ }^{1} \mathrm{H}$ NMR $\left(400 \mathrm{MHz}, \mathrm{CDCl}_{3}\right) \delta(\mathrm{ppm}): 8.22(\mathrm{~d}, J=9.0 \mathrm{~Hz}, 2 \mathrm{H})$, 7.57 (d, $J=9.0 \mathrm{~Hz}, 2 \mathrm{H}), 7.14$ (br S, 1H), 6.10 (s, 2H), 5.46 (s, 2H), 2.54 (s, 6H), 2.42 (s, 6H); ${ }^{13} \mathrm{C}$ NMR (100 MHz, $\mathrm{CDCl}_{3}$ ) $\delta$ (ppm): 157.0, 152.1, 143.4, 143.2, 125.3, 122.5, 117.9, 58.8, 29.7, 15.7, 14.7; LC/MS (Method B): Retention time $13.45 \mathrm{~min}, 441.24[\mathrm{M}-\mathrm{H}]^{+}$; HR-MS(ESI) calcd. for formula $\mathrm{C}_{21} \mathrm{H}_{21} \mathrm{BF}_{2} \mathrm{~N}_{4} \mathrm{O}_{4} \mathrm{Na}[\mathrm{M}+\mathrm{Na}]^{+}$: 465.1522 ; Found: 465.1555 .

\section{b) Synthesis of $\mathbf{2}$ :}

To a stirred solution of $1(25 \mathrm{mg}, 0.056 \mathrm{mmol})$ in dry DMF $(5.0 \mathrm{~mL})$ at room temperature under argon atmosphere

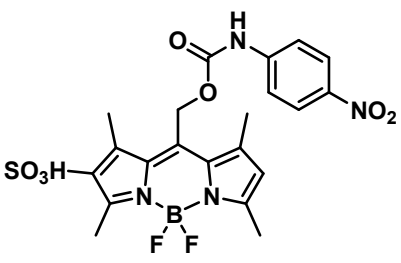

2 was added sulfur trioxide-pyridine $(90 \mathrm{mg}, 0.56 \mathrm{mmol})$. The reaction mixture was stirred for $24 \mathrm{~h}$ at $60^{\circ} \mathrm{C}$. Upon complete consumption of starting material the reaction was stopped and cooled to room temperature. The reaction was diluted with EtOAc $(15.0 \mathrm{~mL})$ and washed with saturated $\mathrm{NH}_{4} \mathrm{Cl}$ solution $(10.0 \mathrm{~mL})$ and brine $(10.0 \mathrm{~mL})$. The water fractions were extracted with EtOAc $(10.0 \mathrm{~mL} \mathrm{X} \mathrm{2).} \mathrm{The} \mathrm{combined} \mathrm{organic}$ phase was dried with $\mathrm{MgSO}_{4}$, filtered and solvents were removed under reduced pressure. The crude was purified by silica gel chromatography $(0-5 \%$ methanol in DCM gradient) to yield $2(15 \mathrm{mg}, 50 \%)$ as an orange solid. ${ }^{1} \mathrm{H}$ NMR (400 MHz, DMSO-d $\left.{ }_{6}\right) \delta(\mathrm{ppm}): 10.65(\mathrm{~S}, 1 \mathrm{H})$, $8.21(\mathrm{~d}, J=9.0 \mathrm{~Hz}, 2 \mathrm{H}), 7.70(\mathrm{~d}, J=9.0 \mathrm{~Hz}, 2 \mathrm{H}), 6.32(\mathrm{~S}, 1 \mathrm{H}), 5.46(\mathrm{~s}, 2 \mathrm{H}), 2.63(\mathrm{~s}, 6 \mathrm{H}), 2.43(\mathrm{~s}, 6 \mathrm{H}) ;{ }^{13} \mathrm{C}$ NMR $(100$ MHz, DMSO-d $\left.{ }_{6}\right) \delta$ (ppm): 157.0, 155.1, 153.1, 145.6, 142.7, 142.4, 138.9, 138.5, 135.3, 132.9, 131.0, 125.6, 123.2, 
118.3, 58.5, 15.9, 14.8, 14.4, 13.3; LC/MS (Method A): Retention time 9.20 min, 521.26 [M-H] ; HR-MS(ESI) calcd. for formula $\mathrm{C}_{21} \mathrm{H}_{20} \mathrm{BF}_{2} \mathrm{~N}_{4} \mathrm{O}_{7} \mathrm{~S}[\mathrm{M}-\mathrm{H}]^{+}$: 521.1114; Found: 521.1122 .

c) Synthesis of 3 :

To a stirred solution of $1(25 \mathrm{mg}, 0.056 \mathrm{mmol})$ in DMF $(5.0 \mathrm{~mL})$ at room temperature under argon atmosphere was

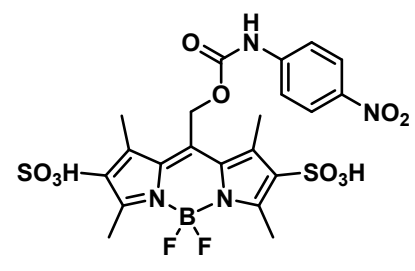

3 added sulfur trioxide-pyridine $(107 \mathrm{mg}, 0.67 \mathrm{mmol})$. The reaction mixture was stirred for $48 \mathrm{~h}$ at $60^{\circ} \mathrm{C}$. The reaction was stopped and cooled to room temperature. Following the removal of the solvent under reduced pressure, the crude product was purified by silica gel chromatography $(0-20 \%$ methanol in DCM gradient) to yield 3 ( $9 \mathrm{mg}$, $26 \%$ ) as an orange solid. ${ }^{1} \mathrm{H}$ NMR $\left(400 \mathrm{MHz}, \mathrm{DMSO}^{-} \mathrm{d}_{6}\right) \delta(\mathrm{ppm}): 10.71(\mathrm{~S}, 1 \mathrm{H}), 8.22$ $(\mathrm{d}, J=9.0 \mathrm{~Hz}, 2 \mathrm{H}), 7.72(\mathrm{~d}, J=9.0 \mathrm{~Hz}, 2 \mathrm{H}), 5.51(\mathrm{~s}, 2 \mathrm{H}), 2.63(\mathrm{~s}, 12 \mathrm{H}) ;{ }^{13} \mathrm{C} \mathrm{NMR}$ $\left(100 \mathrm{MHz}, \mathrm{DMSO}-\mathrm{d}_{6}\right) \delta(\mathrm{ppm}): 155.7,153.1,145.7,142.4,139.0,138.7,136.2,131.6$, 125.5, 118.4, 58.5, 13.5, 10.0; LC/MS (Method A): Retention time $6.32 \mathrm{~min}, 601.01$ [M-H] ${ }^{+}$; HR-MS(ESI) calcd. for formula $\mathrm{C}_{21} \mathrm{H}_{21} \mathrm{BF}_{2} \mathrm{~N}_{4} \mathrm{O}_{10} \mathrm{~S}_{2} \mathrm{Na}[\mathrm{M}+\mathrm{Na}]^{+}$: 625.0658; Found: 625.0653 .

d) Synthesis of 4 :

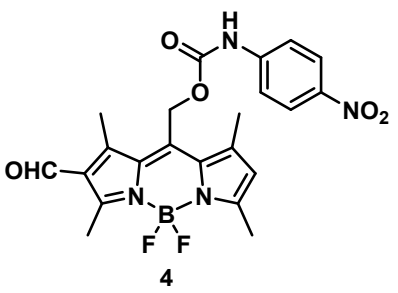

Dry DMF $(1.25 \mathrm{~mL})$ was added to dry DCM $(4 \mathrm{~mL})$ at room temperature under argon atmosphere, and then cooled in an ice bath to $0{ }^{\circ} \mathrm{C} . \mathrm{POCl}_{3}(1.5 \mathrm{~mL})$ was added dropwise and the reaction mixture was warmed to room temperature and stirring was continued for $30 \mathrm{~min}$ at that temperature. $1(25 \mathrm{mg}, 0.057 \mathrm{mmol})$ was added in one portion and the mixture was stirred for $3 \mathrm{~h}$. After that time, reaction mixture was cooled to $0{ }^{\circ} \mathrm{C}$ before the addition of saturated aq. $\mathrm{NaHCO}_{3}(4 \mathrm{~mL})$. The mixture was stirred $30 \mathrm{~min}$ at room temperature and the organic layer was separated. The aqueous layer was extracted with DCM $(3 \times 10 \mathrm{~mL})$ and the combined organic layers were dried over $\mathrm{Na}_{2} \mathrm{SO}_{4}$, filtered, and volatiles were removed in vacuo. The crude mixture was purified by column chromatography $(0-50 \%$ EtOAc in n-Hexane gradient) to afford compound 4 as an orange powder $(14 \mathrm{mg}, 53 \%) .{ }^{1} \mathrm{H}$ NMR $\left(400 \mathrm{MHz}, \mathrm{DMSO} \mathrm{d}_{6}\right) \delta(\mathrm{ppm}): 10.71(\mathrm{~s}, 1 \mathrm{H}), 10.13(\mathrm{~s}, 1 \mathrm{H}), 8.29(\mathrm{~d}, \mathrm{~J}=9.1$ $\mathrm{Hz}, 2 \mathrm{H}), 7.76(\mathrm{~d}, \mathrm{~J}=9.1 \mathrm{~Hz}, 2 \mathrm{H}), 6.67(\mathrm{~s}, 1 \mathrm{H}), 5.60(\mathrm{~s}, 2 \mathrm{H}), 2.78(\mathrm{~d}, \mathrm{~J}=11.2 \mathrm{~Hz}, 6 \mathrm{H}), 2.65-2.33(\mathrm{~m}, 6 \mathrm{H}$, merged with residual DMSO); ${ }^{13} \mathrm{C}$ NMR $\left(100 \mathrm{MHz}, \mathrm{DMSO}_{6}\right) \delta(\mathrm{ppm}): 187.3,155.8,152.8,147.1,145.4,142.3,140.8$, 136.5, 130.0, 126.1, 125.5, 118.2, 58.2, 16.3, 15.3, 13.0, 12.1; LC/MS (Method A): Retention time 10.90 min, 471.17 $[\mathrm{M}+\mathrm{H}]^{+}$; HR-MS(ESI) calcd. for formula $\mathrm{C}_{22} \mathrm{H}_{21} \mathrm{BF}_{2} \mathrm{~N}_{4} \mathrm{O}_{5} \mathrm{Na}[\mathrm{M}+\mathrm{Na}]^{+}$: 493.1471 ; Found: 493.1464. 


\section{Scheme S3:}

Synthetic scheme for $\mathbf{5}$ :

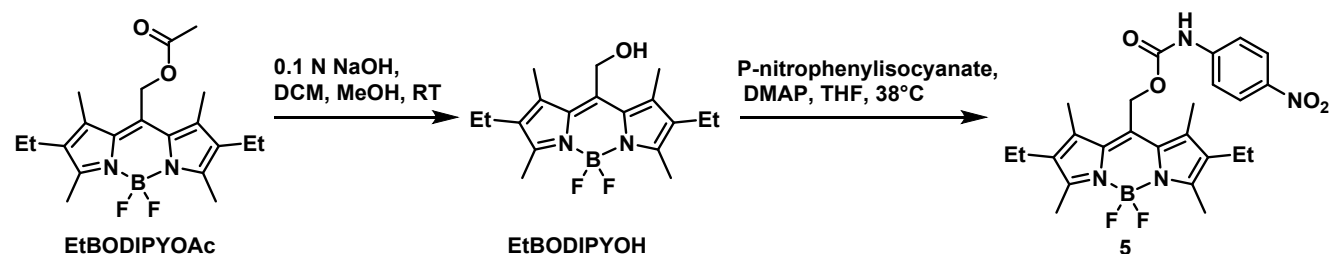

a) Synthesis of EtBODIPYOH:

To a mixture of EtBODIPYOAc $(250 \mathrm{mg}, 0.66 \mathrm{mmol})$ in $\mathrm{CH}_{2} \mathrm{Cl}_{2}(7.5 \mathrm{~mL})$ and methanol $(15 \mathrm{~mL})$ at room temperature<smiles>CCc1c(C)c(CO)c(CC)n1C(F)(F)F</smiles>

EtBODIPYOH under argon atmosphere was added $0.1 \mathrm{M} \mathrm{NaOH}$ solution $(4.0 \mathrm{~mL})$. Stirring was continued for $6 \mathrm{~h}$ at room temperature under argon atmosphere in the dark. Progress of the reaction was monitored by TLC (mobile phase $20 \%$ EtOAc in n-Hexanes). Upon complete consumption of starting material, the reaction mixture was evaporated under reduced pressure. The residue was dissolved in DCM $(30 \mathrm{~mL})$ and washed with saturated $\mathrm{NH}_{4} \mathrm{Cl}$ solution $(20 \mathrm{~mL})$, followed by brine solution $(20 \mathrm{~mL})$. The organic layer was dried with $\mathrm{MgSO}_{4}$ and filtered. Solvent was removed under reduced pressure to obtain a dark brown residue, which was purified by silica gel column chromatography (Eluent: 0 - $12 \%$ EtOAc in n-Hexane gradient) to furnish EtBODIPYOH as dark orange/brown solid (150 mg, $68 \%$ ). LC/MS (Method A): Retention time $10.73 \mathrm{~min}, 335.14[\mathrm{M}+\mathrm{H}]^{+}$. Analytical data for EtBODIPYOH matched those previously reported. ${ }^{3}$

\section{b) Synthesis of 5:}

To a stirred solution of EtBODIPYOH $(70 \mathrm{mg}, 0.21 \mathrm{mmol})$ in dry THF $(4.0 \mathrm{~mL}), p$-nitrophenylisocyanate $(138 \mathrm{mg}$,<smiles></smiles>
$0.84 \mathrm{mmol}$ ) and DMAP (34 $\mathrm{mg}, 0.27 \mathrm{mmol}$ ) were added under argon atmosphere, at room temperature. The reaction mixture was warmed to $38^{\circ} \mathrm{C}$ (oil bath temperature) and stirred for $2 \mathrm{~h}$. Progress of the reaction was monitored by TLC (mobile phase $0-20 \%$ EtOAc in n-Hexanes). Upon complete consumption of starting material, the reaction was diluted with EtOAc $(20.0 \mathrm{~mL})$ and washed with saturated $\mathrm{NH}_{4} \mathrm{Cl}$ solution $(10.0 \mathrm{~mL})$ and brine $(10.0 \mathrm{~mL})$. The water fractions were extracted with EtOAc $(10 \mathrm{~mL} \mathrm{X} \mathrm{2)}$. The combined organic phase was dried with $\mathrm{MgSO}_{4}$, filtered and solvents were removed under reduced pressure. The crude mixture was purified by silica gel chromatography $(0-12 \%$ EtOAc in n-Hexane gradient) to yield $5(90 \mathrm{mg}, 87 \%)$ as a dark orange solid. (110 mg, $0.38 \mathrm{mmol})$. LC/MS (Method A): Retention time $13.61 \mathrm{~min}, 499.45[\mathrm{M}+\mathrm{H}]^{+}$. Analytical data for EtBODIPYPNA matched those previously reported. ${ }^{3}$

c) Synthesis of $\mathbf{6}$ :

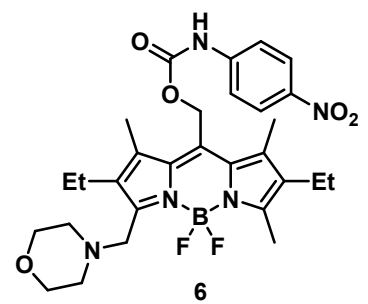

To a stirred solution of $5(15 \mathrm{mg}, 0.03 \mathrm{mmol})$ in dry $\mathrm{CH}_{2} \mathrm{Cl}_{2}(2 \mathrm{~mL})$ at room temperature under argon atmosphere was added $N$-bromosuccinimide $(6 \mathrm{mg}, 0.03 \mathrm{mmol})$. The reaction mixture was stirred for $30 \mathrm{~min}$ at that temperature. Morpholine $(100 \mu \mathrm{L}, 1.14 \mathrm{mmol})$ was added to the reaction mixture and stirring was continued for $2 \mathrm{~h}$ at room temperature. The reaction mixture was evaporated under reduced pressure to obtain a dark brown residue, which was purified by silica gel column chromatography (Eluent: 0 - $12 \%$ EtOAc in nHexane gradient) to furnish 6 as a dark orange/brown solid (12 mg, $68 \%$ ). ${ }^{1} \mathrm{H}$ NMR (400 
$\left.\mathrm{MHz}, \mathrm{CDCl}_{3}\right) \delta(\mathrm{ppm}): 8.23(\mathrm{~d}, J=9.1 \mathrm{~Hz}, 2 \mathrm{H}), 7.58(\mathrm{~d}, J=9.1 \mathrm{~Hz}, 2 \mathrm{H}), 7.18(\mathrm{~s}, 1 \mathrm{H}), 5.49(\mathrm{~s}, 2 \mathrm{H}), 3.80(\mathrm{~s}, 2 \mathrm{H}), 3.67$ (s, 4H), $2.43-2.58(\mathrm{~m}, 9 \mathrm{H}), 2.34-2.41(\mathrm{~m}, 8 \mathrm{H}), 1.12(\mathrm{t}, J=7.5 \mathrm{~Hz}, 3 \mathrm{H}), 1.02(\mathrm{t}, J=7.5 \mathrm{~Hz}, 3 \mathrm{H}) ;{ }^{13} \mathrm{C}$ NMR $(100$ $\left.\mathrm{MHz}, \mathrm{CDCl}_{3}\right) \delta(\mathrm{ppm}): 157.4,153.6,152.1,143.3,143.2,137.4,136.6,135.0,134.7,132.8,131.6,131.2,125.3,117.9$, 67.2, 59.2, 54.3, 53.7, 29.7, 17.4, 17.1, 14.6 (2), 12.9, 12.6; LC/MS (Method A): Retention time 10.59 min, 584.41 $[\mathrm{M}+\mathrm{H}]^{+}$; HR-MS(ESI) calcd. for formula $\mathrm{C}_{29} \mathrm{H}_{35} \mathrm{BF}_{2} \mathrm{~N}_{5} \mathrm{O}_{5}[\mathrm{M}-\mathrm{H}]^{+}: 582.2699$; Found: 582.2704.

d) Synthesis of 7 :

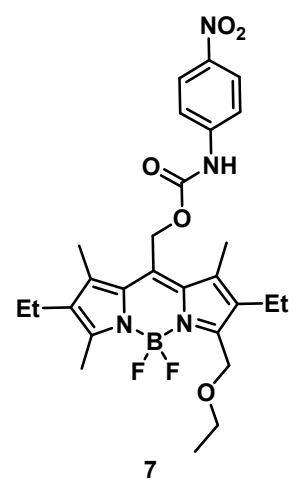

min, $565.36[\mathrm{M}+\mathrm{Na}]^{+}$; HR-MS(ESI) calcd. for formula $\mathrm{C}_{27} \mathrm{H}_{33} \mathrm{BF}_{2} \mathrm{~N}_{4} \mathrm{O}_{5} \mathrm{Na}[\mathrm{M}+\mathrm{Na}]^{+}$: 565.2410; Found: 565.2413.

To a stirred solution of $5(70 \mathrm{mg}, 0.14 \mathrm{mmol})$ in dry DCM $(2.0 \mathrm{~mL})$ at room temperature under argon atmosphere was added N-bromosuccinimide ( $25 \mathrm{mg}, 0.14 \mathrm{mmol})$. After stirring for $1.5 \mathrm{~h}$ at room temperature ethanol $(2 \mathrm{~mL})$ was added to the reaction mixture and stirring was continued for $2 \mathrm{~h}$. The reaction mixture was evaporated under reduced pressure. The crude was purified by silica gel chromatography $(0-15 \%$ EtOAc in n-Hexane gradient) to yield 7 (36 $\mathrm{mg}, 47 \%$ ) as an orange solid. ${ }^{1} \mathrm{H} \mathrm{NMR}\left(400 \mathrm{MHz}, \mathrm{CDCl}_{3}\right) \delta(\mathrm{ppm}): 8.15(\mathrm{~d}, J=9.0 \mathrm{~Hz}, 2 \mathrm{H})$, $7.60(\mathrm{~s}, 1 \mathrm{H}), 7.55(\mathrm{~d}, J=9.0 \mathrm{~Hz}, 2 \mathrm{H}), 5.46(\mathrm{~s}, 2 \mathrm{H}), 4.75(\mathrm{~s}, 2 \mathrm{H}), 3.57$ (q, $J=7.0 \mathrm{~Hz}, 2 \mathrm{H}), 2.55$ (s, 3H), 2.49 (q, $J=7.5 \mathrm{~Hz}, 2 \mathrm{H}), 2.41$ (q, $J=7.5 \mathrm{~Hz}, 2 \mathrm{H}), 2.35$ (s, 3H), 2.30 (s, 3H), 1.19 (t, $J$ $=7.0 \mathrm{~Hz}, 3 \mathrm{H}), 1.05(\mathrm{t}, J=7.0 \mathrm{~Hz}, 6 \mathrm{H}) ;{ }^{13} \mathrm{C} \mathrm{NMR}\left(100 \mathrm{MHz}, \mathrm{CDCl}_{3}\right) \delta(\mathrm{ppm}): 159.0,152.2$, 150.9, 143.6, 143.1, 138.4, 136.0, 135.2, 134.3, 133.7, 132.0, 131.5, 125.1, 117.9, 66.3, 63.7, 59.1, 17.2, 17.1, 15.2, 14.9, 14.5, 13.1, 12.8, 12.4; LC/MS (Method A): Retention time 13.81 e) Synthesis of $\mathbf{8}$ :

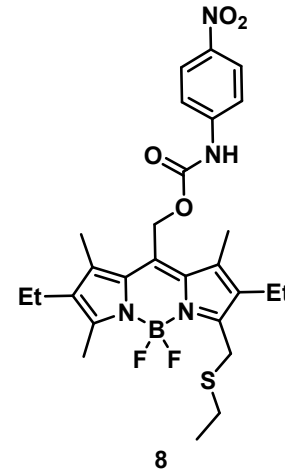

HR-MS(ESI) calcd. for formula $\mathrm{C}_{27} \mathrm{H}_{33} \mathrm{BF}_{2} \mathrm{~N}_{4} \mathrm{O}_{4} \mathrm{SNa}[\mathrm{M}+\mathrm{Na}]^{+}$: 581.2181 ; Found: 581.2186.

To a stirred solution of $5(30 \mathrm{mg}, 0.06 \mathrm{mmol})$ in dry DCM $(2.0 \mathrm{~mL})$ at room temperature under argon atmosphere was added N-bromosuccinimide (11 mg, $0.06 \mathrm{mmol})$. After stirring for $2 \mathrm{~h}$ at room temperature Ethanethiol $(100 \mu \mathrm{L})$ was added to the reaction mixture and stirring was continued for $2 \mathrm{~h}$. The reaction mixture was evaporated under reduced pressure. The crude mixture was purified by silica gel chromatography $(0-10 \%$ EtOAc in n-Hexane gradient $)$ to yield $8(15 \mathrm{mg}, 45 \%)$ as orange solid. ${ }^{1} \mathrm{H}$ NMR $\left(400 \mathrm{MHz}, \mathrm{CDCl}_{3}\right) \delta(\mathrm{ppm}): 8.18(\mathrm{~d}, J=9.1$ $\mathrm{Hz}, 2 \mathrm{H}), 7.56(\mathrm{~d}, J=9.1 \mathrm{~Hz}, 2 \mathrm{H}), 7.44(\mathrm{~S}, 1 \mathrm{H}), 5.48(\mathrm{~s}, 2 \mathrm{H}), 4.00(\mathrm{~s}, 2 \mathrm{H}), 2.66(\mathrm{q}, J=7.4 \mathrm{~Hz}$, 2H), 2.49-2.55 (m, 5H), 2.45 (q, $J=7.5 \mathrm{~Hz}, 2 \mathrm{H}), 2.34(\mathrm{~s}, 6 \mathrm{H}), 1.26(\mathrm{t}, J=7.0 \mathrm{~Hz}, 3 \mathrm{H}), 1.14(\mathrm{t}$, $J=7.4 \mathrm{~Hz}, 3 \mathrm{H}), 1.06(\mathrm{t}, J=7.5 \mathrm{~Hz}, 3 \mathrm{H}) ;{ }^{13} \mathrm{C} \mathrm{NMR}\left(100 \mathrm{MHz}, \mathrm{CDCl}_{3}\right) \delta(\mathrm{ppm}): 157.62,152.6$, 152.2, 143.5, 143.2, 137.7, 136.7, 134.8, 133.8, 131.2, 125.2, 117.9, 59.1, 29.7, 27.2, 27.0, 17.2, 17.1, 14.8, 14.6, 12.8, 12.7; LC/MS (Method A): Retention time $14.13 \mathrm{~min}, 557.12[\mathrm{M}-\mathrm{H}]^{+}$; f) Synthesis of 9 :

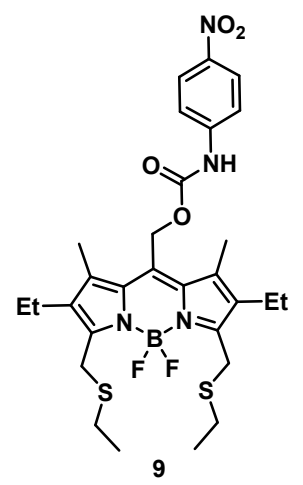

To a stirred solution of $5(20 \mathrm{mg}, 0.04 \mathrm{mmol})$ in dry DCM $(2.0 \mathrm{~mL})$ at room temperature under argon atmosphere was added N-bromosuccinimide (14 mg, $0.08 \mathrm{mmol})$. After stirring for $2 \mathrm{~h}$ at room temperature ethanethiol $(200 \mu \mathrm{L})$ was added to the reaction mixture and stirring was continued for $2 \mathrm{~h}$. The reaction mixture was evaporated under reduced pressure. The crude mixture was purified by reverse phase prep-HPLC [Method A]. Fractions containing desired compound were evaporated under reduced pressure to remove acetonitrile. Residue was extracted from aqueous phase in DCM $(20 \mathrm{~mL})$ and washed with brine solution $(15 \mathrm{~mL})$. The organic layer was dried with $\mathrm{MgSO}_{4}$, filtered and solvent was removed under reduced pressure to yield $9(10 \mathrm{mg}, 40 \%)$ as an orange solid. ${ }^{1} \mathrm{H}$ NMR $\left(400 \mathrm{MHz}, \mathrm{CDCl}_{3}\right) \delta(\mathrm{ppm}): 8.18(\mathrm{~d}, J=$ $9.1 \mathrm{~Hz}, 2 \mathrm{H}), 7.57$ (d, $J=9.1 \mathrm{~Hz}, 2 \mathrm{H}), 7.44$ (s, 1H), 5.49 (s, 2H), 4.01 (s, 4H), 2.65 (q, $J=7.3$ 
$\mathrm{Hz}, 4 \mathrm{H}), 2.49$ (q, $J=7.5 \mathrm{~Hz}, 4 \mathrm{H}), 2.35(\mathrm{~s}, 6 \mathrm{H}), 1.13-1.27(\mathrm{~m}, 6 \mathrm{H}), 1.12(\mathrm{t}, J=7.5 \mathrm{~Hz}, 6 \mathrm{H}) ;{ }^{13} \mathrm{C}$ NMR $(100 \mathrm{MHz}$, $\left.\mathrm{CDCl}_{3}\right) \delta(\mathrm{ppm}): 155.0,152.1,143.4,143.2,138.0,134.7,132.6,131.9,125.2,117.9,59.1,29.7,27.1,26.9,17.2$, 14.7, 12.8; LC/MS (Method A): Retention time $14.65 \mathrm{~min}, 617.45[\mathrm{M}-\mathrm{H}]^{+}$; HR-MS(ESI) calcd. for formula $\mathrm{C}_{29} \mathrm{H}_{37} \mathrm{BF}_{2} \mathrm{~N}_{4} \mathrm{O}_{4} \mathrm{~S}_{2} \mathrm{Na}[\mathrm{M}+\mathrm{Na}]^{+}$: 641.2215; Found: 641.2184 .

\section{Scheme S4:}

Synthetic scheme for $\mathbf{1 0}$ and 11:

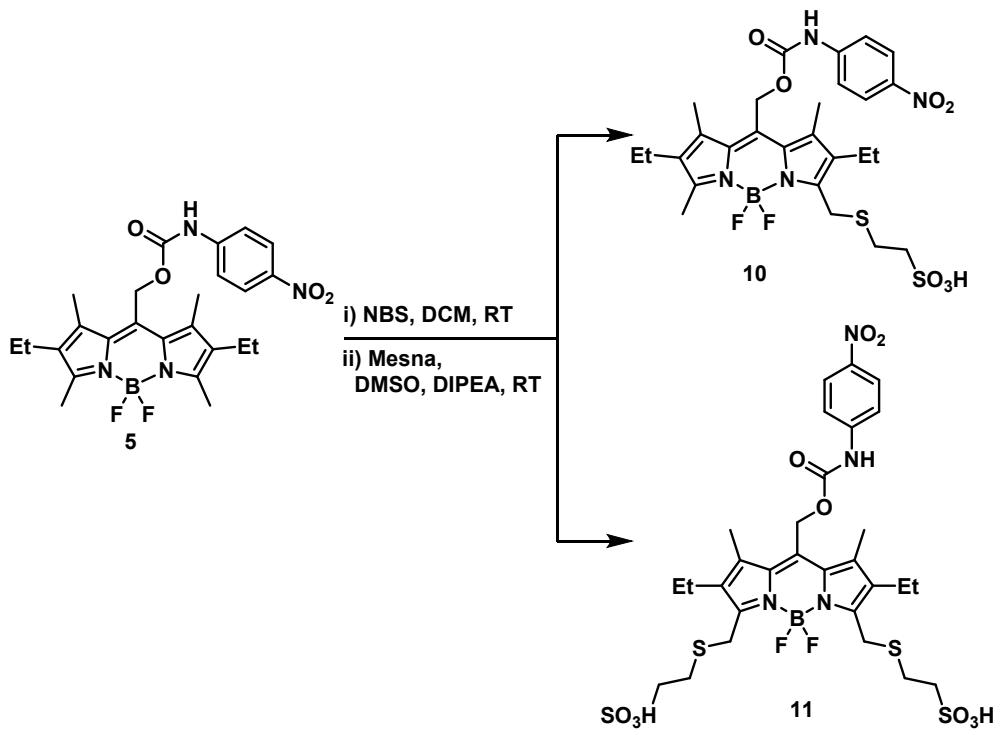

a) Synthesis of 10:

To a stirred solution of $5(20 \mathrm{mg}, 0.04 \mathrm{mmol})$ in dry DCM $(2.0 \mathrm{~mL})$ at room temperature under argon atmosphere was<smiles></smiles>
added $N$-bromosuccinimide $(7 \mathrm{mg}, 0.04 \mathrm{mmol})$. The reaction mixture was stirred at that temperature for $1.5 \mathrm{~h}$. Progress of the reaction was monitored by TLC (mobile phase 20 $\%$ EtOAc in n-Hexanes). Upon complete consumption of starting material, a solution of MESNA $(66 \mathrm{mg}, 0.4 \mathrm{mmol})$ in dry DMSO $(0.5 \mathrm{~mL})$ was added to the reaction mixture. Resulting solution was stirred at RT under argon atmosphere for $2 \mathrm{~h}$. The reaction mixture was diluted with DCM $(10.0 \mathrm{~mL})$ followed by addition of water $(5.0 \mathrm{~mL})$. The water fractions were extracted with DCM $(5.0 \mathrm{~mL} \mathrm{X} \mathrm{2).} \mathrm{The} \mathrm{combined} \mathrm{organic} \mathrm{phase}$ was dried with $\mathrm{MgSO}_{4}$, filtered and solvents were removed under reduced pressure. The crude was purified by silica gel chromatography $(0-10 \%$ methanol in DCM) to yield $\mathbf{1 0}(13 \mathrm{mg}, 50 \%)$ as a dark orange solid. ${ }^{1} \mathrm{H}$ NMR $\left(400 \mathrm{MHz}, \mathrm{CD}_{3} \mathrm{OD}\right) \delta(\mathrm{ppm}): 8.11(\mathrm{~d}, J=9.2 \mathrm{~Hz}, 2 \mathrm{H}), 7.61(\mathrm{~d}, J=9.2 \mathrm{~Hz}, 2 \mathrm{H}), 5.42(\mathrm{~s}, 2 \mathrm{H})$ $3.98(\mathrm{~s}, 2 \mathrm{H}), 2.91-2.99(\mathrm{~m}, 4 \mathrm{H}), 2.46(\mathrm{q}, J=7.3 \mathrm{~Hz}, 2 \mathrm{H}), 2.38-2.41(\mathrm{~m}, 5 \mathrm{H}), 2.31(\mathrm{~s}, 3 \mathrm{H}), 2.30(\mathrm{~s}, 3 \mathrm{H}), 1.06(\mathrm{t}, J=6.3$ $\mathrm{Hz}, 3 \mathrm{H}), 0.98(\mathrm{t}, J=6.3 \mathrm{~Hz}, 3 \mathrm{H}) ;{ }^{13} \mathrm{C} \mathrm{NMR}\left(100 \mathrm{MHz}, \mathrm{CD}_{3} \mathrm{OD}\right) \delta(\mathrm{ppm}): 155.8,151.5,149.6,143.5,141.1,136.8$, 135.5, 133.0, 131.8, 131.6, 131.3, 130.1, 122.9, 116.0, 56.8, 50.1, 37.4, 25.3, 25.1, 15.2, 14.9, 12.3, 12.0, 10.1, 9.8; LC/MS (Method B): Retention time 10.89 min, 637.78 [M-H] ; HR-MS(ESI) calcd. for formula $\mathrm{C}_{27} \mathrm{H}_{32} \mathrm{BF}_{2} \mathrm{~N}_{4} \mathrm{O}_{7} \mathrm{~S}_{2}[\mathrm{M}-$ $\mathrm{H}]^{+}:$637.1774; Found: 637.1773 . 
To a stirred solution of $5(15 \mathrm{mg}, 0.03 \mathrm{mmol})$ in dry DCM $(2.0 \mathrm{~mL})$ at room temperature under argon atmosphere was

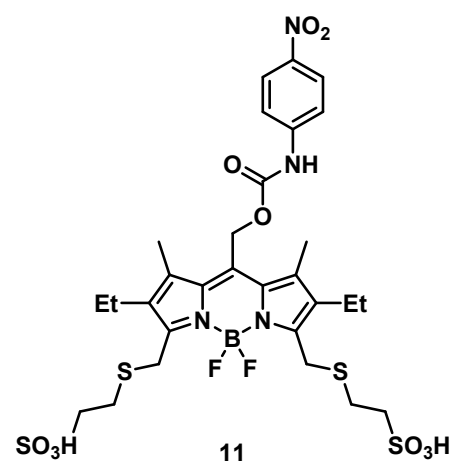
added $N$-bromosuccinimide $(11 \mathrm{mg}, 0.06 \mathrm{mmol})$. The reaction mixture was stirred at that temperature for $2 \mathrm{~h}$. Progress of the reaction was monitored by TLC (mobile phase $40 \%$ EtOAc in n-Hexanes). Upon complete consumption of starting material, a solution of Mesna $(50 \mathrm{mg}, 0.3 \mathrm{mmol})$ in dry DMSO $(0.5 \mathrm{~mL})$ was added to the reaction mixture. Resulting solution was stirred at RT under argon atmosphere for $2 \mathrm{~h}$. The reaction mixture was evaporated under reduced pressure. The crude was purified by reverse phase prep-HPLC [Method A]. Fractions containing desired compound were immediately frozen and lyophilized to afford $\mathbf{1 1}(8 \mathrm{mg}, 33 \%)$ as a dark orange solid. ${ }^{1} \mathrm{H}$ NMR $\left(400 \mathrm{MHz}, \mathrm{DMSO}-\mathrm{d}_{6}\right) \delta(\mathrm{ppm}): 10.76(\mathrm{~s}, 1 \mathrm{H}), 8.22(\mathrm{~d}$, $J=9.2 \mathrm{~Hz}, 2 \mathrm{H}), 7.71(\mathrm{~d}, J=9.2 \mathrm{~Hz}, 2 \mathrm{H}), 5.45(\mathrm{~s}, 2 \mathrm{H}) 4.01(\mathrm{~s}, 4 \mathrm{H}), 2.75-2.79(\mathrm{~m}$, $4 \mathrm{H}), 2.56-2.61(\mathrm{~m}, 4 \mathrm{H}), 2.33(\mathrm{~s}, 6 \mathrm{H}), 1.07(\mathrm{t}, J=7.3 \mathrm{~Hz}, 6 \mathrm{H}) ;{ }^{13} \mathrm{C} \mathrm{NMR}(100 \mathrm{MHz}$,

DMSO-d $\left._{6}\right) \delta(\mathrm{ppm}): 154.5,153.1,145.7,142.3,138.9,134.5,134.1,132.4,126.9,125.6,118.2,112.9,58.9,51.9$, 28.2, 27.2, 17.1, 15.1, 12.8; LC/MS (Method B): Retention time $9.13 \mathrm{~min}, 777.21$ [M-H] $]^{+}$HR-MS(ESI) calcd. for formula $\mathrm{C}_{29} \mathrm{H}_{36} \mathrm{BF}_{2} \mathrm{~N}_{4} \mathrm{O}_{10} \mathrm{~S}_{4}[\mathrm{M}-\mathrm{H}]^{+}$: 777.1375; Found: 777.1375 .

\section{Scheme S5:}

Synthetic scheme for monomesna EtBODIPYPNP:

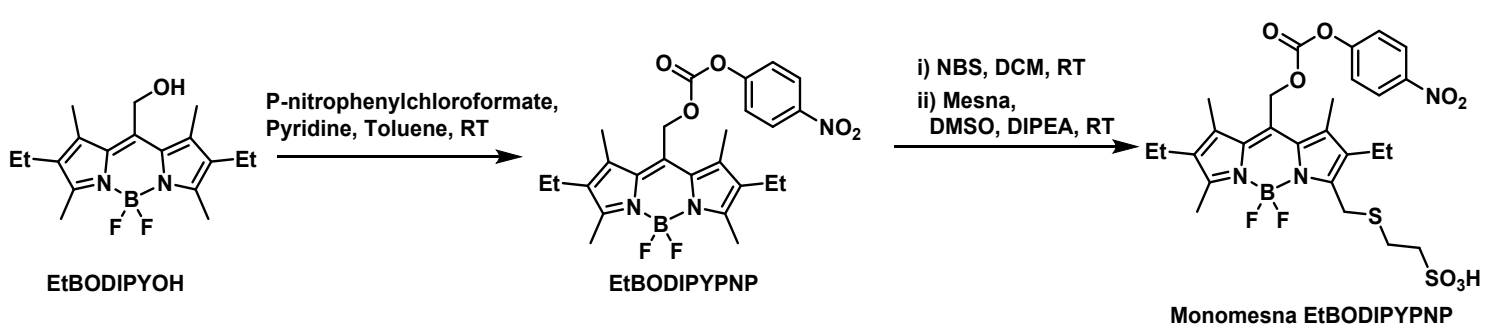

a) Synthesis of EtBODIPYPNP:

To a stirred solution of EtBODIPYOH $(100 \mathrm{mg}, 0.30 \mathrm{mmol})$ in toluene $(10 \mathrm{~mL})$ at room temperature under argon

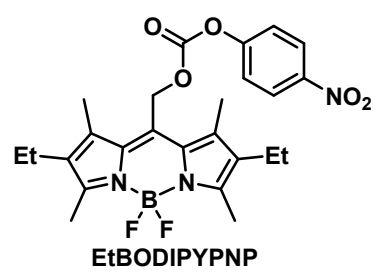
atmosphere, $p$-nitrophenylchloroformate $(241 \mathrm{mg}, 1.20 \mathrm{mmol})$ and pyridine $(197 \mu \mathrm{L}, 1.5$ $\mathrm{mmol}$ ) were added. The reaction mixture was stirred at room temperature for $3 \mathrm{~h}$. Upon completion, the reaction was diluted with EtOAc $(10 \mathrm{~mL})$ and washed with saturated $\mathrm{NH}_{4} \mathrm{Cl}$ solution $(10 \mathrm{~mL})$ and brine $(10 \mathrm{~mL})$, dried with $\mathrm{MgSO} 4$, filtered and solvents were removed under reduced pressure. The crude product was purified by reverse phase prep-HPLC [Method A]. Fractions containing desired compound were evaporated under reduced pressure to remove acetonitrile. Residue was extracted from aqueous phase in $\operatorname{DCM}(20 \mathrm{~mL})$ and washed with brine solution $(15 \mathrm{~mL})$. The organic layer was dried with $\mathrm{MgSO}_{4}$, filtered and solvent was removed under reduced pressure to yield EtBODIPYPNP (110 mg, $74 \%$ ) as orange solid. LC/MS (Method A): Retention time $12.72 \mathrm{~min}, 500.18[\mathrm{M}+\mathrm{H}]^{+}$. Analytical data for EtBODIPYPNP matched those previously reported. ${ }^{3}$ 
b) Synthesis of MonomesnaEtBODIPYPNP:

To a stirred solution of EtBODIPYPNP $(70 \mathrm{mg}, 0.14 \mathrm{mmol})$ in dry DCM $(2.0 \mathrm{~mL})$ at room temperature under argon

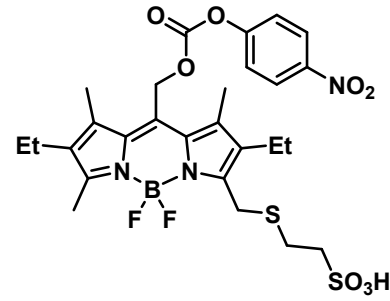

Monomesna EtBODIPYPNP atmosphere was added $N$-bromosuccinimide $(25 \mathrm{mg}, 0.14 \mathrm{mmol})$. The reaction mixture was stirred at that temperature for $2 \mathrm{~h}$. Progress of the reaction was monitored by TLC (mobile phase $20 \%$ EtOAc in n-Hexanes). Upon complete consumption of starting material, solution of MESNA (50 mg, $0.3 \mathrm{mmol})$ in dry DMSO $(0.5 \mathrm{~mL})$ was added to the reaction mixture. Resulting reaction mixture was stirred at RT under argon atmosphere for $2 \mathrm{~h}$. The reaction mixture was evaporated under reduced pressure. The crude was purified by silica gel chromatography $(0-10 \%$ methanol in DCM) to yield

DMSO-d $\left._{6}\right) \delta(\mathrm{ppm}): 8.33(\mathrm{~d}, J=9.2 \mathrm{~Hz}, 2 \mathrm{H}), 7.64(\mathrm{~d}, J=9.2 \mathrm{~Hz}, 2 \mathrm{H}), 5.62(\mathrm{~s}, 2 \mathrm{H}), 3.98(\mathrm{~s}, 2 \mathrm{H}), 2.76-2.84(\mathrm{~m}, 2 \mathrm{H})$, 2.60-2.72 (m, 4H), $2.47(\mathrm{~s}, 3 \mathrm{H}), 2.42(\mathrm{~d}, J=7.2 \mathrm{~Hz}, 2 \mathrm{H}), 2.38(\mathrm{~s}, 3 \mathrm{H}), 2.36(\mathrm{~s}, 3 \mathrm{H}) 1.66(\mathrm{t}, J=6.6 \mathrm{~Hz}, 3 \mathrm{H}), 1.60(\mathrm{t}, J$ $=6.6 \mathrm{~Hz}, 3 \mathrm{H}) ;{ }^{13} \mathrm{C}$ NMR $\left(101 \mathrm{MHz}, \mathrm{DMSO}_{-} \mathrm{d}_{6}\right) \delta(\mathrm{ppm}): 157.7,155.6,152.4,152.1,145.8,137.7,135.0,133.7,132.8$, 131.9, 126.6, 125.9, 123.2, 116.2, 62.2, 51.9, 28.4, 27.1, 17.1, 16.9, 15.2, 14.9, 13.2, 13.0, 12.8; LC/MS (Method B): Retention time $10.51 \mathrm{~min}, 638.38[\mathrm{M}-\mathrm{H}]^{+}$; HR-MS(ESI) calcd. for formula $\mathrm{C}_{27} \mathrm{H}_{31} \mathrm{BF}_{2} \mathrm{~N}_{3} \mathrm{O}_{8} \mathrm{~S}_{2}[\mathrm{M}-\mathrm{H}]^{+}: 638.1614$; Found: 638.1625 .

c) Synthesis of 12:<smiles></smiles>

EtBODIPYPNP
Dopamine.HCI, DIPEA, $\stackrel{\mathrm{THF} / \mathrm{DMSO}, \mathrm{RT}}{\longrightarrow}$

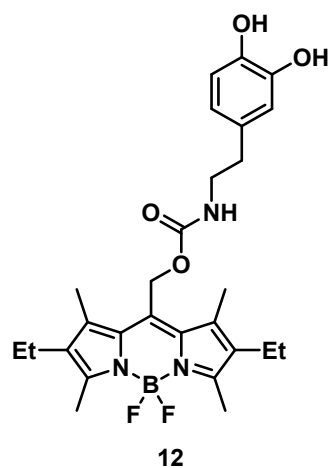

To a stirred solution of EtBODIPYPNP $(25 \mathrm{mg}, 0.05 \mathrm{mmol})$ in dry THF $(3.0 \mathrm{~mL})$ at room temperature under argon atmosphere was added a solution of dopamine $\mathrm{HCl}(14 \mathrm{mg}, 0.075 \mathrm{mmol})$ and DIPEA (26 $\mu \mathrm{L}, 0.15 \mathrm{mmol})$ in dry DMSO $(1.0 \mathrm{~mL})$. The reaction mixture was stirred at that temperature for $2 \mathrm{~h}$. Upon completion, the reaction was evaporated under reduced pressure. The crude mixture was purified by silica gel chromatography $(0-10 \%$ methanol in DCM) to yield $12(15 \mathrm{mg}, 58 \%)$ as an orange solid. LC/MS (Method A): Retention time $10.82 \mathrm{~min}, 536.31[\mathrm{M}+\mathrm{Na}]^{+}$. Analytical data complies with previously reported analytical data. ${ }^{3}$

d) Synthesis of 13:

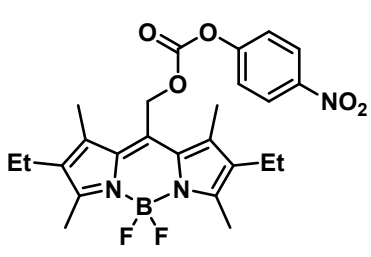

EtBODIPYPNP
Histamine.2HCl, DIPEA, THF/DMSO, RT

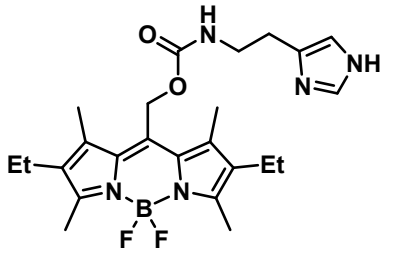

13 
To a stirred solution of EtBODIPYPNP (30 mg, $0.06 \mathrm{mmol})$ in dry THF $(2 \mathrm{~mL})$ at room temperature under argon atmosphere was added a solution of histamine dihydrochloride $(16 \mathrm{mg}, 0.09 \mathrm{mmol})$ and DIPEA ( $52 \mu \mathrm{L}, 0.3 \mathrm{mmol})$ in DMSO $(1 \mathrm{~mL})$. The reaction mixture was stirred for $1.5 \mathrm{~h}$ at room temperature and evaporated under reduced pressure. The crude product was purified by silica gel chromatography ( 0 - $10 \%$ methanol in DCM) to yield $\mathbf{1 3}$ (20 $\mathrm{mg}, 71 \%)$ as an orange solid. 1H NMR (400 MHz, $\mathrm{CDCl}_{3}+1$ drop $\left.\mathrm{CD}_{3} \mathrm{OD}\right) \delta 7.49(\mathrm{~s}, 1 \mathrm{H}), 6.73(\mathrm{~s}, 1 \mathrm{H}), 5.25(\mathrm{~s}, 2 \mathrm{H}), 3.41(\mathrm{~s}$, 2H), $2.75(\mathrm{t}, \mathrm{J}=6.3 \mathrm{~Hz}, 2 \mathrm{H}), 2.45(\mathrm{~s}, 6 \mathrm{H}), 2.34(\mathrm{dd}, \mathrm{J}=14.8,7.3 \mathrm{~Hz}, 4 \mathrm{H}), 2.24(\mathrm{~s}, 6 \mathrm{H}), 1.00(\mathrm{t}, \mathrm{J}=7.5 \mathrm{~Hz}, 6 \mathrm{H}) .{ }^{13} \mathrm{C}$ NMR (101 MHz, $\mathrm{CDCl}_{3}+1$ drop $\left.\mathrm{CD}_{3} \mathrm{OD}\right) \delta(\mathrm{ppm}): 156.3,154.9,136.9,134.9,133.6,132.3,132.1,116.5,58.4,40.7$, 40.6, 27.3, 17.2, 14.7, 12.7, 12.6; LC/MS (Method A): Retention time 9.54 min, 472.19 [M+H] ${ }^{+}$; HR-MS(ESI) calcd. for formula $\mathrm{C}_{24} \mathrm{H}_{33} \mathrm{BF}_{2} \mathrm{~N}_{5} \mathrm{O}_{2}[\mathrm{M}+\mathrm{H}]^{+}:$472.2695; Found: 472.2694 .

e) Synthesis of 14:
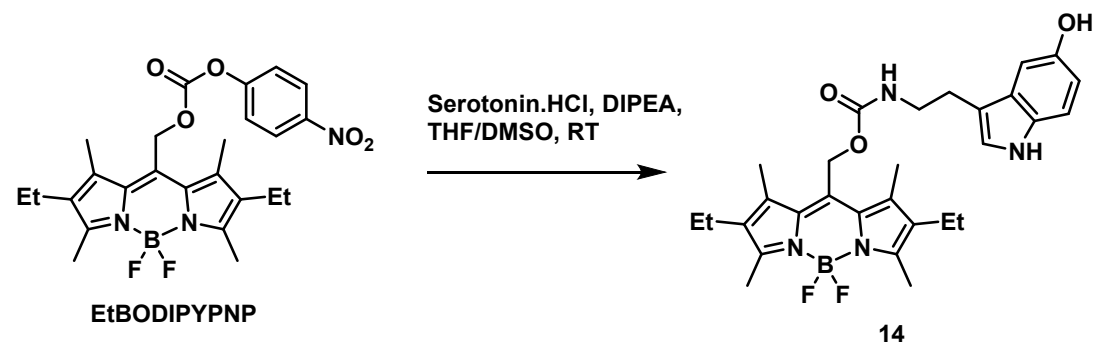

To a stirred solution of EtBODIPYPNP $(20 \mathrm{mg}, 0.04 \mathrm{mmol})$ in dry THF $(1.0 \mathrm{~mL})$ at room temperature under argon atmosphere was added a solution of serotonin $\cdot \mathrm{HCl}(17 \mathrm{mg}, 0.08 \mathrm{mmol})$ and DIPEA $(21 \mu \mathrm{L}, 0.12 \mathrm{mmol})$ in dry DMSO $(1.5 \mathrm{~mL})$. The reaction mixture was stirred at that temperature for $4 \mathrm{~h}$. Upon completion, the reaction mixture was diluted with EtOAc $(8.0 \mathrm{~mL})$ and washed with saturated $\mathrm{NH}_{4} \mathrm{Cl}$ solution $(6.0 \mathrm{~mL})$ and brine $(6.0 \mathrm{~mL})$, dried with $\mathrm{MgSO}_{4}$, filtered and solvents were removed under reduced pressure. The crude product was purified by silica gel chromatography ( 0 - 1\% methanol in DCM) to yield $14(15 \mathrm{mg}, 71 \%)$ as an orange solid. ${ }^{1} \mathrm{H}$ NMR $\left(400 \mathrm{MHz}, \mathrm{CD}_{3} \mathrm{OD}\right)$ $\delta(\mathrm{ppm}): 7.07(\mathrm{~d}, J=8.6 \mathrm{~Hz}, 1 \mathrm{H}), 6.90(\mathrm{~s}, 1 \mathrm{H}), 6.85(\mathrm{~d}, J=2.0 \mathrm{~Hz}, 1 \mathrm{H}), 6.58(\mathrm{dd}, J=8.6$ and $2.0 \mathrm{~Hz}, 1 \mathrm{H}), 5.19$ (s, 2H), 3.33 (t, $J=7.2 \mathrm{~Hz}, 2 \mathrm{H}), 2.79$ (t, $J=7.2 \mathrm{~Hz}, 2 \mathrm{H}), 2.33(\mathrm{~m}, 10 \mathrm{H}), 2.19(\mathrm{~s}, 6 \mathrm{H}), 0.96(\mathrm{t}, J=7.3 \mathrm{~Hz}, 6 \mathrm{H}) ;{ }^{13} \mathrm{C}$ NMR (100 MHz, $\left.\mathrm{CD}_{3} \mathrm{OD}\right) \delta(\mathrm{ppm}): 155.3,152.6,148.1,135.4,131.6,131.3,130.5,130.1,126.5,121.3,109.6,109.3,100.5$, 56.3, 39.7, 23.7, 14.9, 12.1, 9.7; LC/MS (Method A): Retention time 11.74 min, 559.47 [M+Na] $]^{+}$; HR-MS(ESI) calcd. for formula $\mathrm{C}_{29} \mathrm{H}_{34} \mathrm{BF}_{2} \mathrm{~N}_{4} \mathrm{O}_{3}[\mathrm{M}-\mathrm{H}]^{+}:$535.2692; Found: 535.2688.

\section{f) Synthesis of 15:}

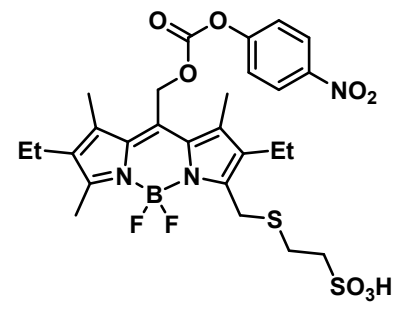

Monomesna EtBODIPYPNP

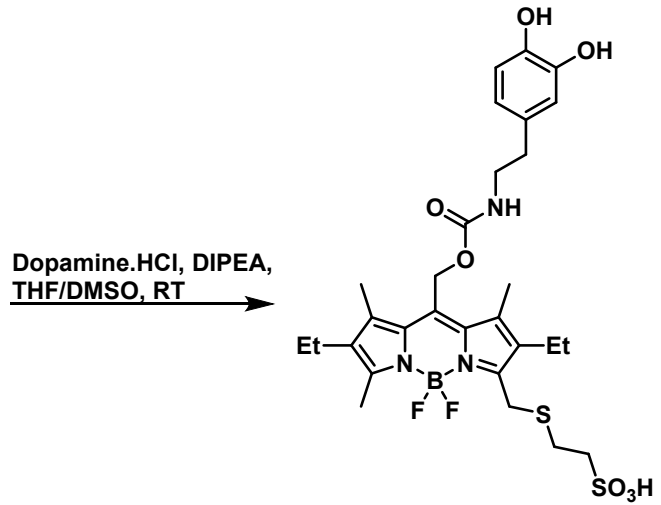

15 
To a stirred solution of MonomesnaEtBODIPYPNP $(28 \mathrm{mg}, 0.044 \mathrm{mmol})$ in dry THF. ( $3.0 \mathrm{~mL})$ at room temperature under argon atmosphere was added a solution of dopamine $\mathrm{HCl}(10 \mathrm{mg}, 0.053 \mathrm{mmol})$ and DIPEA $(23 \mu \mathrm{L}, 0.13 \mathrm{mmol})$ in dry DMSO $(1.0 \mathrm{~mL})$. The reaction mixture was stirred at that temperature for $2 \mathrm{~h}$. Upon completion, the reaction was evaporated under reduced pressure. The crude mixture was purified by reverse phase prep-HPLC [Method B]. Fractions containing desired compound were immediately frozen and lyophilized to afford $\mathbf{1 5}(14.0 \mathrm{mg}, 48 \%)$ as an orange solid. ${ }^{1} \mathrm{H}$ NMR (400 MHz, MeOD) $\delta(\mathrm{ppm}): 6.74(\mathrm{dd}, J=11.0,4.8 \mathrm{~Hz}, 2 \mathrm{H}), 6.60(\mathrm{dd}, J=8.0,1.6 \mathrm{~Hz}, 1 \mathrm{H})$, $5.36(\mathrm{~s}, 2 \mathrm{H}), 4.71(\mathrm{~s}, 2 \mathrm{H}), 4.12(\mathrm{~s}, 2 \mathrm{H}), 3.14-3.03(\mathrm{~m}, 4 \mathrm{H}), 2.72(\mathrm{t}, J=7.1 \mathrm{~Hz}, 2 \mathrm{H}), 2.64(\mathrm{dd}, J=14.8,7.4 \mathrm{~Hz}, 2 \mathrm{H})$, $2.57-2.50(\mathrm{~m}, 5 \mathrm{H}), 2.38(\mathrm{~d}, J=4.3 \mathrm{~Hz}, 6 \mathrm{H}), 1.22(\mathrm{t}, J=7.5 \mathrm{~Hz}, 3 \mathrm{H}), 1.14(\mathrm{t}, J=7.5 \mathrm{~Hz}, 3 \mathrm{H}) ;{ }^{13} \mathrm{C}$ NMR $(101 \mathrm{MHz}$, MeOD) $\delta(\mathrm{ppm}): 156.9,156.7,150.8,144.7,143.2,138.3,136.9,134.3,133.5,133.1,131.5,130.3,119.6,115.4$, 114.8, 57.7, 51.6, 42.0, 34.8, 26.8, 26.5, 16.6, 16.3, 13.7, 13.4, 11.4, 11.3, 11.1; LC/MS (Method B): Retention time $9.37 \mathrm{~min}, 652.29[\mathrm{M}-\mathrm{H}]^{+}$; HR-MS(ESI) calcd. for formula $\mathrm{C}_{29} \mathrm{H}_{37} \mathrm{BF}_{2} \mathrm{~N}_{3} \mathrm{O}_{7} \mathrm{~S}_{2}[\mathrm{M}-\mathrm{H}]^{+}:$652.2134; Found: 652.2117.

g) Synthesis of 16:

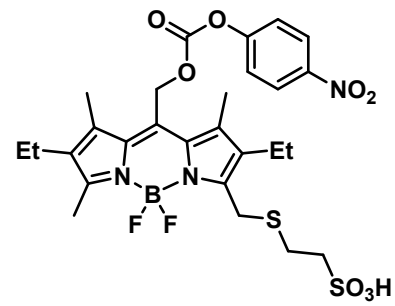

Monomesna EtBODIPYPNP

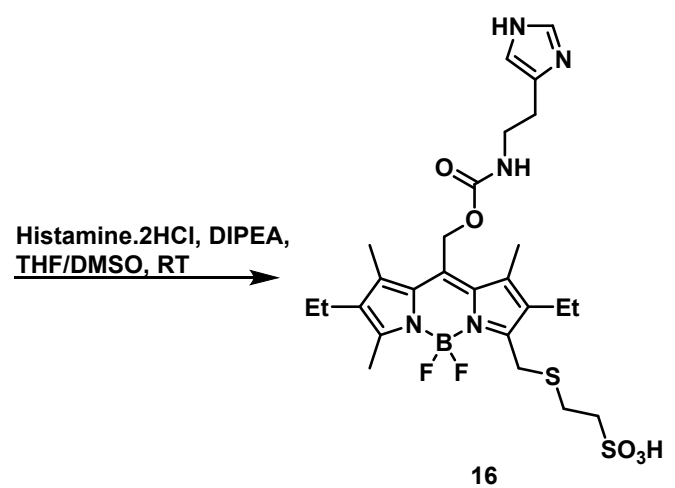

16

To a stirred solution of MonomesnaEtBODIPYPNP (30 mg, $0.047 \mathrm{mmol})$ in dry THF. (3.0 mL). at room temperature under argon atmosphere was added a solution of histamine $2 \mathrm{HCl}(11 \mathrm{mg}, 0.056 \mathrm{mmol})$ and DIPEA $(29 \mu \mathrm{L}, 0.16 \mathrm{mmol})$ in dry DMSO $(1.0 \mathrm{~mL})$. The reaction mixture was stirred at that temperature for $2 \mathrm{~h}$ and evaporated under reduced pressure. The crude mixture was purified by reverse phase prep-HPLC [Method B]. Fractions containing desired compound were immediately frozen and lyophilized to afford $\mathbf{1 6}(12.0 \mathrm{mg}, 41 \%)$ as an orange solid. ${ }^{1} \mathrm{H}$ NMR (400 $\left.\mathrm{MHz}, \mathrm{CD}_{3} \mathrm{OD}\right) \delta(\mathrm{ppm}): 8.75(\mathrm{~s}, 1 \mathrm{H}), 7.34(\mathrm{~s}, 1 \mathrm{H}), 5.40(\mathrm{~s}, 2 \mathrm{H}), 4.13(\mathrm{~s}, 2 \mathrm{H}), 3.53(\mathrm{t}, \mathrm{J}=6.5 \mathrm{~Hz}, 2 \mathrm{H}), 3.43(\mathrm{~s}, 1 \mathrm{H})$, $3.05(\mathrm{~s}, 4 \mathrm{H}), 2.97(\mathrm{t}, \mathrm{J}=6.4 \mathrm{~Hz}, 2 \mathrm{H}), 2.64(\mathrm{dd}, \mathrm{J}=15.0,7.5 \mathrm{~Hz}, 2 \mathrm{H}), 2.59-2.48(\mathrm{~m}, 5 \mathrm{H}), 2.41(\mathrm{~s}, 3 \mathrm{H}), 2.38(\mathrm{~s}, 3 \mathrm{H})$, $1.22(\mathrm{t}, \mathrm{J}=7.5 \mathrm{~Hz}, 3 \mathrm{H}), 1.14(\mathrm{t}, \mathrm{J}=7.5 \mathrm{~Hz}, 3 \mathrm{H}) .{ }^{13} \mathrm{C} \mathrm{NMR}\left(101 \mathrm{MHz}, \mathrm{CD}_{3} \mathrm{OD}\right) \delta(\mathrm{ppm})$ 157.0, 156.5, 151.0, 138.2, 136.8, 134.3, 133.6, 133.4, 133.1, 132.9, 131.5, 131.4, 116.3, 57.7, 51.6, 39.0, 29.2, 26.5, 24.8, 16.6, 16.3, 13.7, 13.4, 11.5, 11.2; LC/MS (Method B): Retention time $8.70 \mathrm{~min}, 610.28[\mathrm{M}-\mathrm{H}]^{+}$; HR-MS(ESI) calcd. for formula $\mathrm{C}_{26} \mathrm{H}_{35} \mathrm{BF}_{2} \mathrm{~N}_{5} \mathrm{O}_{5} \mathrm{~S}_{2}[\mathrm{M}-\mathrm{H}]^{+}:$610.2141; Found: 610.2158 . 


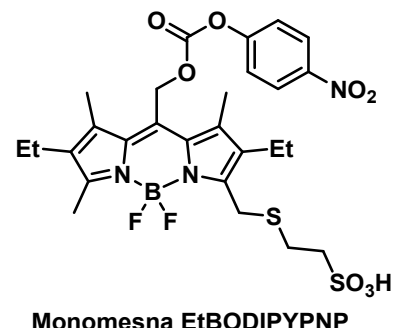

Monomesna EtBODIPYPNP

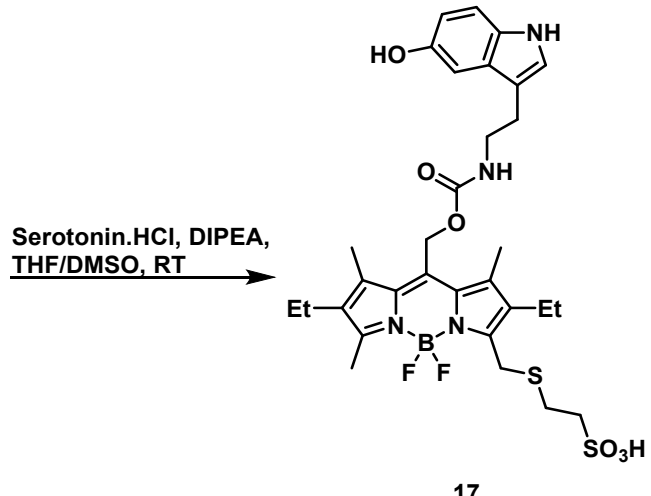

17

To a stirred solution of MonomesnaEtBODIPYPNP $(15 \mathrm{mg}, 0.02 \mathrm{mmol})$ in dry THF $(1.0 \mathrm{~mL})$ at room temperature under argon atmosphere was added a solution of serotonin $\cdot \mathrm{HCl}(15 \mathrm{mg}, 0.07 \mathrm{mmol})$ and DIPEA $(24 \mu \mathrm{L}, 0.14 \mathrm{mmol})$ in dry DMSO $(1.0 \mathrm{~mL})$. The reaction mixture was stirred at that temperature for $2 \mathrm{~h}$. Upon completion, the reaction was evaporated under reduced pressure. The crude was purified by reverse phase prep-HPLC [Method B]. Fractions containing desired compound were immediately frozen and lyophilized to afford $\mathbf{1 7}(7.0 \mathrm{mg}, 45 \%)$ as an orange solid. ${ }^{1} \mathrm{H}$ NMR (400 MHz, DMSO-d $\left.{ }_{6}\right) \delta(\mathrm{ppm}): 10.48(\mathrm{~s}, 1 \mathrm{H}), 8.57(\mathrm{~s}, 1 \mathrm{H}), 7.60(\mathrm{t}, J=5.6 \mathrm{~Hz}, 1 \mathrm{H}), 7.11(\mathrm{~d}, J=8.6 \mathrm{~Hz}, 1 \mathrm{H})$, $7.00(\mathrm{~s}, 1 \mathrm{H}), 6.80(\mathrm{~d}, J=2.0 \mathrm{~Hz}, 1 \mathrm{H}), 6.57(\mathrm{dd}, J=8.6$ and $2.0 \mathrm{~Hz}, 1 \mathrm{H}), 5.22(\mathrm{~s}, 2 \mathrm{H}), 3.96(\mathrm{~s}, 2 \mathrm{H}), 3.26(\mathrm{q}, J=6.5$ $\mathrm{Hz}, 2 \mathrm{H}), 2.70-2.77$ (m, 4H), 2.56-2.60 (m, 2H), 2.44 (s, 3H), 2.37 (q, J=7.9 Hz, 4H), 2.28 (s, 3H), 2.26 (s, 3H), 1.06 $(\mathrm{t}, J=7.4 \mathrm{~Hz}, 3 \mathrm{H}), 0.99$ (t, $J=7.5 \mathrm{~Hz}, 3 \mathrm{H}) ;{ }^{13} \mathrm{C}$ NMR $\left(100 \mathrm{MHz}, \mathrm{DMSO}-\mathrm{d}_{6}\right) \delta(\mathrm{ppm}): 156.8,156.1,151.7,150.6$, 138.8, 137.6, 134.6, 134.5, 133.1, 132.8, 131.5, 131.2, 128.3, 123.6, 112.1, 111.6, 110.8, 102.5, 57.8, 51.9, 41.5, 28.2, 27.1, 25.8, 17.1, 16.9, 15.2, 15.0, 13.1, 12.8, 12.5; LC/MS (Method B): Retention time 9.74 min, 675.29 [M-H] $]^{+}$HRMS(ESI) calcd. for formula $\mathrm{C}_{31} \mathrm{H}_{38} \mathrm{BF}_{2} \mathrm{~N}_{4} \mathrm{O}_{6} \mathrm{~S}_{2}[\mathrm{M}-\mathrm{H}]^{+}$: 675.2294; Found: 675.2277.

i) Synthesis of 18:

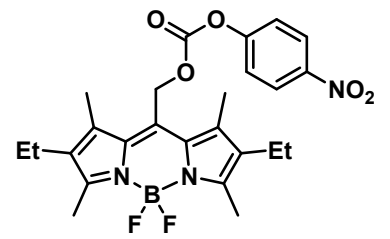

EtBODIPYPNP
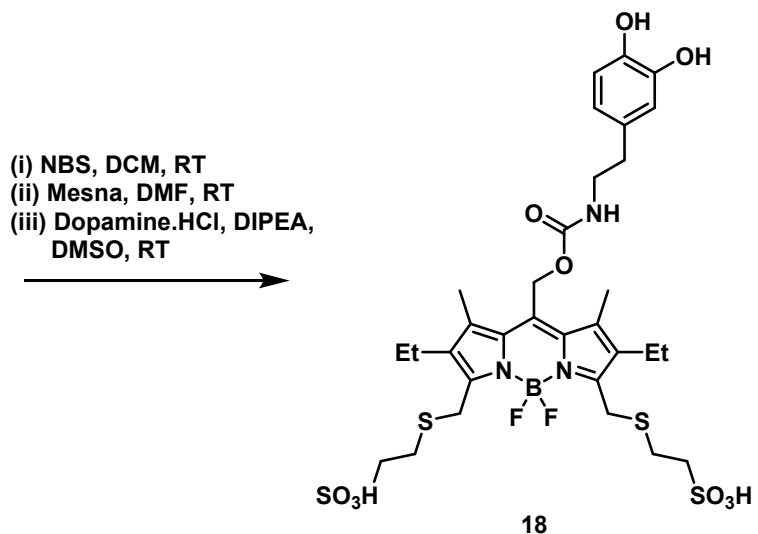

18

To a stirred solution of EtBODIPYPNP $(20 \mathrm{mg}, 0.04 \mathrm{mmol})$ in dry DCM. $(3.0 \mathrm{~mL})$ at room temperature under argon atmosphere was added $N$-bromosuccinimide $(16 \mathrm{mg}, 0.088 \mathrm{mmol})$. After $2 \mathrm{~h}$, solution of MESNA $(15 \mathrm{mg}, 0.088 \mathrm{mmol})$ in dry DMF $(1.0 \mathrm{~mL})$ was added to the reaction mixture. Resulting reaction mixture was stirred at RT under argon atmosphere for $12 \mathrm{~h}$. Then a solution of dopamine $\mathrm{HCl}(9 \mathrm{mg}, 0.048 \mathrm{mmol})$ and DIPEA (11 $\mu \mathrm{L}, 0.064 \mathrm{mmol})$ in dry DMSO $(1.0 \mathrm{~mL})$ was added to the reaction mixture. The reaction mixture was stirred at room temperature for $2 \mathrm{~h}$. The crude was purified by reverse phase prep-HPLC [Method B]. Fractions containing desired compound were 
immediately frozen and lyophilized to afford $18(17.0 \mathrm{mg}, 54 \%)$ as an orange solid. ${ }^{1} \mathrm{H}$ NMR (400 MHz, DMSO-d 6 ) $\delta(\mathrm{ppm}): 8.80(\mathrm{~s}, 1 \mathrm{H}), 8.71(\mathrm{~s}, 1 \mathrm{H}), 7.64(\mathrm{~d}, \mathrm{~J}=5.2 \mathrm{~Hz}, 1 \mathrm{H}), 6.74-6.56(\mathrm{~m}, 1 \mathrm{H}), 6.48(\mathrm{~d}, \mathrm{~J}=8.0 \mathrm{~Hz}, 1 \mathrm{H}), 5.34(\mathrm{~m}$, 2H), $4.06(\mathrm{~s}, 4 \mathrm{H}), 3.21(\mathrm{~d}, \mathrm{~J}=6.3 \mathrm{~Hz}, 2 \mathrm{H}), 2.96-2.79(\mathrm{~m}, 6 \mathrm{H}), 2.77-2.62(\mathrm{~m}, 4 \mathrm{H}), 2.55(\mathrm{~d}, \mathrm{~J}=10.7 \mathrm{~Hz}, 4 \mathrm{H}), 2.44$ $-2.21(\mathrm{~m}, 6 \mathrm{H}), 1.15(\mathrm{t}, \mathrm{J}=7.4 \mathrm{~Hz}, 6 \mathrm{H}) ;{ }^{13} \mathrm{C}$ NMR $\left(100 \mathrm{MHz}, \mathrm{DMSO}-\mathrm{d}_{6}\right) \delta(\mathrm{ppm}): 13 \mathrm{C}$ NMR (101 MHz, DMSO) $\delta$ 153.9, 145.3, 143.8, 138.9, 134.1, 132.3, 130.3, 119.6, 116.3, 115.7, 55.6, 51.8, 28.6, 28.3, 27.1, 20.2, 17.0, 15.0, 12.6; LC/MS (Method B): Retention time $7.91 \mathrm{~min}, 792.31$ [M-H] $]^{+}$; HR-MS(ESI) calcd. for formula $\mathrm{C}_{31} \mathrm{H}_{41} \mathrm{BF}_{2} \mathrm{~N}_{3} \mathrm{O}_{10} \mathrm{~S}_{4}[\mathrm{M}-$ $\mathrm{H}]^{+}:$792.1736; Found: 792.1747.

\section{j) Synthesis of 19:}

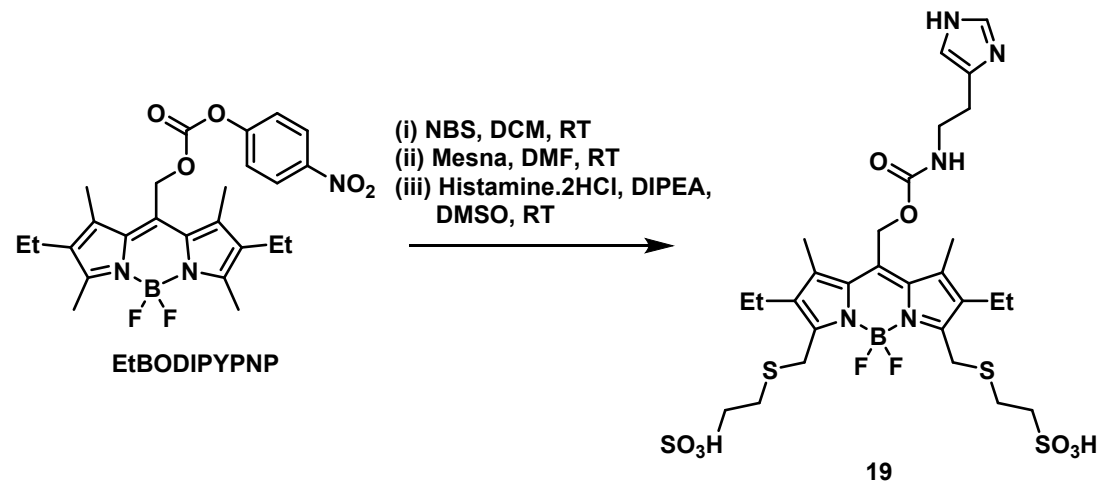

To a stirred solution of EtBODIPYPNP $(20 \mathrm{mg}, 0.04 \mathrm{mmol})$ in dry DCM $(2.0 \mathrm{~mL})$ at room temperature under argon atmosphere was added $N$-bromosuccinimide $(16 \mathrm{mg}, 0.088 \mathrm{mmol})$. After $2 \mathrm{~h}$, solution of MESNA ( $15 \mathrm{mg}, 0.088 \mathrm{mmol})$ in dry DMF $(1.0 \mathrm{~mL})$ was added to the reaction mixture. Resulting reaction mixture was stirred at RT under argon atmosphere for $12 \mathrm{~h}$. Then a solution of histamine $2 \mathrm{HCl}(10 \mathrm{mg}, 0.052 \mathrm{mmol})$ and DIPEA ( $23 \mu \mathrm{L}, 0.13 \mathrm{mmol})$ in dry DMSO $(1.0 \mathrm{~mL})$ was added to the reaction mixture. The reaction mixture was stirred at room temperature for $2 \mathrm{~h}$. The crude was purified by reverse phase prep-HPLC [Method B]. Fractions containing desired compound were immediately frozen and lyophilized to afford $19(11.0 \mathrm{mg}, 37 \%)$ as an orange solid. ${ }^{1} \mathrm{H}$ NMR (400 MHz, DMSO-d $\left.\mathrm{d}_{6}\right)$ $\delta(\mathrm{ppm}): 9.05(\mathrm{~s}, 1 \mathrm{H}), 7.74(\mathrm{t}, J=5.7 \mathrm{~Hz} 1 \mathrm{H}), 7.48(\mathrm{~s}, 1 \mathrm{H}), 5.23(\mathrm{~s}, 2 \mathrm{H}), 4.06(\mathrm{~s}, 4 \mathrm{H}), 2.81-2.89(\mathrm{~m}, 8 \mathrm{H}), 2.64-2.69$ $(\mathrm{m}, 6 \mathrm{H}), 2.4(\mathrm{t}, J=6.1 \mathrm{~Hz} 2 \mathrm{H}), 2.32(\mathrm{~s}, 6 \mathrm{H}), 1.15(\mathrm{t}, J=7.2 \mathrm{~Hz}, 6 \mathrm{H}) ;{ }^{13} \mathrm{C}$ NMR $(101 \mathrm{MHz}$, DMSO-d 6 ) $\delta 155.9,154.0$, 138.8, 135.1, 134.2, 132.2, 131.0, 117.3, 116.80, 51.70, 34.1, 29.0, 28.1, 27.0, 25.0, 17.0, 15.0, 12.6; LC/MS (Method B): Retention time $7.10 \mathrm{~min}, 750.46[\mathrm{M}-\mathrm{H}]^{+}$; HR-MS(ESI) calcd. for formula $\mathrm{C}_{28} \mathrm{H}_{39} \mathrm{BF}_{2} \mathrm{~N}_{5} \mathrm{O}_{8} \mathrm{~S}_{4}[\mathrm{M}-\mathrm{H}]^{+}: 750.1743$; Found: 750.1761 .

k) Synthesis of 20:

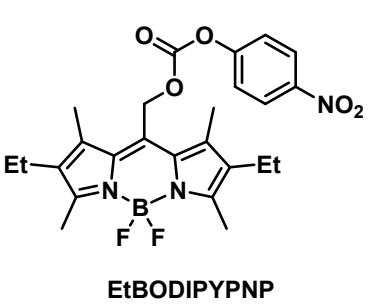

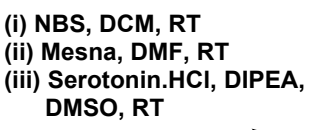

Page S28 
To a stirred solution of EtBODIPYPNP $(25 \mathrm{mg}, 0.05 \mathrm{mmol})$ in dry DCM $(2.0 \mathrm{~mL})$ at room temperature under argon atmosphere was added $N$-bromosuccinimide $(20 \mathrm{mg}, 0.11 \mathrm{mmol})$. After $2 \mathrm{~h}$, solution of MESNA (17 mg, $0.11 \mathrm{mmol})$ in dry DMF $(1.0 \mathrm{~mL})$ was added to the reaction mixture. Resulting reaction mixture was stirred at RT under argon atmosphere for $12 \mathrm{~h}$. Then a solution of serotonin $\mathrm{HCl}(12 \mathrm{mg}, 0.055 \mathrm{mmol})$ and DIPEA (16 $\mu \mathrm{L}, 0.10 \mathrm{mmol})$ in dry DMSO $(1.0 \mathrm{~mL})$ was added to the reaction mixture. The reaction mixture was stirred at room temperature for $2 \mathrm{~h}$. The crude was purified by Reverse phase Prep-HPLC [Method B]. Fractions containing desired compound were immediately frozen and lyophilized to afford $20(21.0 \mathrm{mg}, 51 \%)$ as an orange solid. ${ }^{1} \mathrm{H}$ NMR $\left(400 \mathrm{MHz}, \mathrm{DMSO}-\mathrm{d}_{6}\right)$ $\delta(\mathrm{ppm}): 10.49(\mathrm{~s}, 1 \mathrm{H}), 8.59(\mathrm{~s}, 1 \mathrm{H}), 7.66(\mathrm{t}, J=5.6 \mathrm{~Hz}, 1 \mathrm{H}), 7.16(\mathrm{~s}, 1 \mathrm{H}), 7.02(\mathrm{~s}, 1 \mathrm{H}), 6.82(\mathrm{~s}, 1 \mathrm{H}), 6.59(\mathrm{dd}, J=8.6$ and $2.0 \mathrm{~Hz}, 1 \mathrm{H}), 5.25(\mathrm{~s}, 2 \mathrm{H}), 4.00(\mathrm{~s}, 4 \mathrm{H}), 3.24(\mathrm{q}, J=6.7 \mathrm{~Hz}, 2 \mathrm{H}), 2.77-2.81(\mathrm{~m}, 5 \mathrm{H}), 2.69-2.75(\mathrm{~m}, 4 \mathrm{H}), 2.60-2.64$ $(\mathrm{m}, 5 \mathrm{H}), 2.29(\mathrm{~s}, 6 \mathrm{H}), 1.08(\mathrm{t}, J=7.4 \mathrm{~Hz}, 6 \mathrm{H}) ;{ }^{13} \mathrm{C}$ NMR (100 MHz, DMSO-d 6 ) $\delta(\mathrm{ppm}): 156.0,154.0,150.6,139.0$, 135.5, 134.2, 131.2, 128.3, 123.6, 112.0, 111.6, 110.8, 102.5, 57.8, 51.9, 41.5, 28.4, 27.2, 25.8, 17.1, 15.1, 12.7; LC/MS (Method B): Retention time 8.14 min, $815.22[\mathrm{M}-\mathrm{H}]^{+}$; HR-MS(ESI) calcd. for formula $\mathrm{C}_{33} \mathrm{H}_{42} \mathrm{BF}_{2} \mathrm{~N}_{4} \mathrm{O}_{9} \mathrm{~S}_{4}[\mathrm{M}-$ $\mathrm{H}]^{+}:$815.1896; Found: 815.1844.

\section{l) Synthesis of 21:}

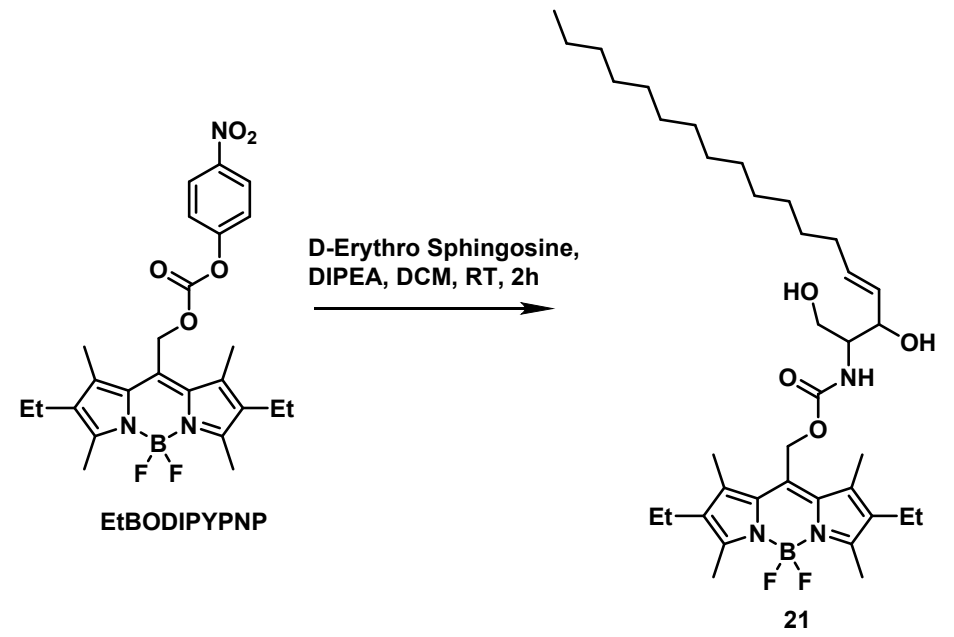

To a stirred solution of EtBODIPYPNP $(9 \mathrm{mg}, 0.017 \mathrm{mmol})$ in dry THF $(3.0 \mathrm{~mL})$ at room temperature under argon atmosphere was added a solution of D-erythro-sphingosine $(5 \mathrm{mg}, 0.017 \mathrm{mmol})$ and DIPEA ( $3 \mu \mathrm{L}, 0.17 \mathrm{mmol})$ in dry THF $(0.5 \mathrm{~mL})$. The reaction mixture was stirred at that temperature for $2 \mathrm{~h}$. Upon completion, the reaction was evaporated under reduced pressure. The crude mixture was purified by silica gel column chromatography (Eluent: 0 $-30 \%$ EtOAc in DCM gradient) to furnish 21 as a dark orange solid $(9 \mathrm{mg}, 76 \%) .{ }^{1} \mathrm{H} \mathrm{NMR}\left(400 \mathrm{MHz}, \mathrm{CDCl}_{3}\right) \delta$ (ppm): $5.87-5.71(\mathrm{~m}, 1 \mathrm{H}), 5.66-5.47(\mathrm{~m}, 2 \mathrm{H}), 5.35(\mathrm{~s}, 2 \mathrm{H}), 4.35(\mathrm{~s}, 1 \mathrm{H}), 3.99(\mathrm{~d}, J=11.3 \mathrm{~Hz}, 1 \mathrm{H}), 3.81-3.63(\mathrm{~m}$, 2H), $2.51(\mathrm{~s}, 6 \mathrm{H}), 2.39$ (q, $J=7.6 \mathrm{~Hz}, 4 \mathrm{H}), 2.31(\mathrm{~s}, 6 \mathrm{H}), 2.26(\mathrm{~d}, J=4.8 \mathrm{~Hz}, 1 \mathrm{H}), 2.12-1.98(\mathrm{~m}, 2 \mathrm{H}), 1.27(\mathrm{~d}, J=$ $16.8 \mathrm{~Hz}, 21 \mathrm{H}), 1.05(\mathrm{t}, J=7.6 \mathrm{~Hz}, 6 \mathrm{H}), 0.88(\mathrm{t}, J=6.8 \mathrm{~Hz}, 3 \mathrm{H}) ;{ }^{13} \mathrm{C} \mathrm{NMR}\left(101 \mathrm{MHz}, \mathrm{CDCl}_{3}\right) \delta(\mathrm{ppm}): \delta 155.96$, 154.8, 136.5, 134.5, 133.4, 132.1, 131.6, 128.5, 74.6, 62.2, 58.4, 55.5, 32.1, 31.8, 29.6, 29.4, 29.2, 29.1, 28.9, 22.6, 17.0, 14.6, 14.0, 12.5. LC/MS (Method A): Retention time $14.98 \mathrm{~min}, 682.52$ [M+Na] ${ }^{+}$, HR-MS(ESI) calcd. for formula $\mathrm{C}_{37} \mathrm{H}_{59} \mathrm{BF}_{2} \mathrm{~N}_{3} \mathrm{O}_{4}[\mathrm{M}-\mathrm{H}]^{+}$: 658.4561; Found: 658.4561 . 
m) Synthesis of 22:
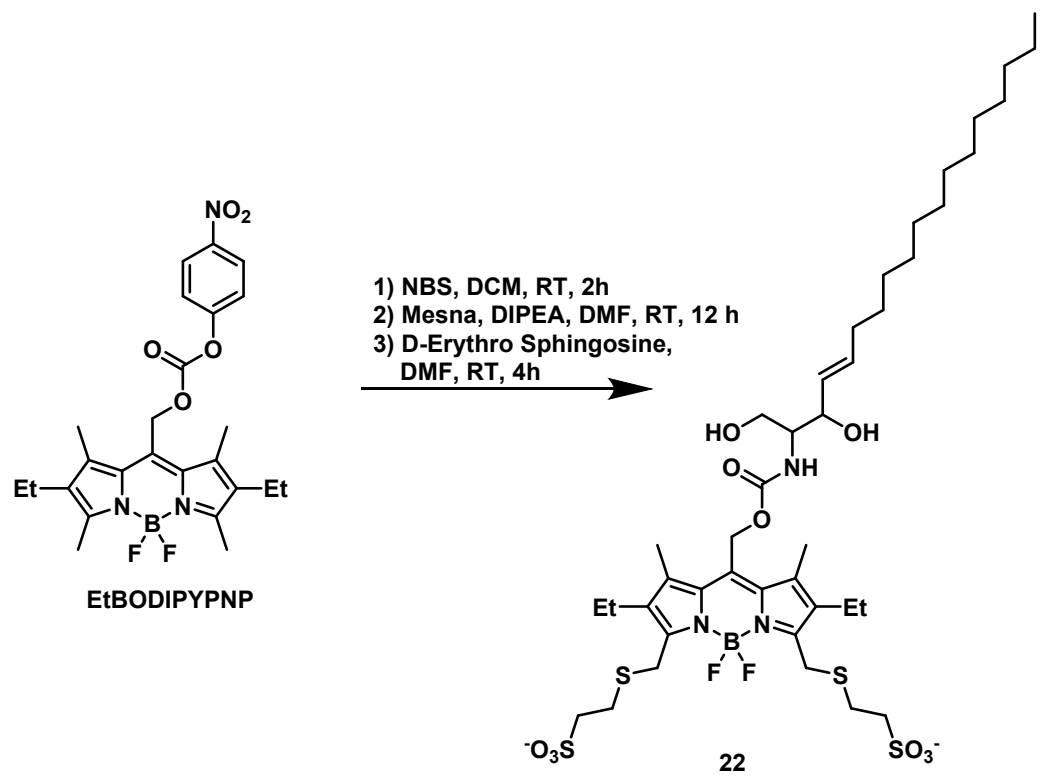

To a stirred solution of EtBODIPYPNP $(20 \mathrm{mg}, 0.04 \mathrm{mmol})$ in dry DCM $(2.0 \mathrm{~mL})$ at room temperature under argon atmosphere was added $N$-bromosuccinimide $(16 \mathrm{mg}, 0.088 \mathrm{mmol})$. After $2 \mathrm{~h}$, solution of MESNA ( $15 \mathrm{mg}, 0.088 \mathrm{mmol})$ and DIPEA $(15 \mu \mathrm{L}, 0.088 \mathrm{mmol})$ in dry DMF $(1.0 \mathrm{~mL})$ was added to the reaction mixture. Resulting reaction mixture was stirred at RT under argon atmosphere for $12 \mathrm{~h}$. Then a solution of D-erythro-sphingosine (12 $\mathrm{mg}, 0.04 \mathrm{mmol})$ ) in dry DMF $(1.0 \mathrm{~mL})$ was added to the reaction mixture. The reaction mixture was stirred at room temperature for $4 \mathrm{~h}$. The crude was purified by reverse phase prep-HPLC [Method B]. Fractions containing desired compound were immediately frozen and lyophilized to afford $22(1.5 \mathrm{mg}, 4 \%)$ as an orange solid. ${ }^{1} \mathrm{H}$ NMR $\left(400 \mathrm{MHz}, \mathrm{DMSO}-\mathrm{d}_{6}\right) \delta$ (ppm): 5.60-5.67 (m, 1H), 5.43 (dd, $J=6.6$ and $15.4 \mathrm{~Hz} 1 \mathrm{H}), 4.76(\mathrm{~s}, 2 \mathrm{H}), 4.0-4.03(\mathrm{~m}, 5 \mathrm{H}), 3.51-3.55(\mathrm{~m}, 5 \mathrm{H}), 3.35-$ 3.40 (m, 9H), 2.79-2.88 (m, 5H), 2.63-2.67 (m, 5H), 2.46-2.52 (m, 5H), $2.44(\mathrm{~s}, 6 \mathrm{H}), 1.99(\mathrm{q}, J=6.8 \mathrm{~Hz}, 1 \mathrm{H}), 1.12-$ $1.34(\mathrm{~m}, 11 \mathrm{H}), 1.10(\mathrm{t}, J=7.4 \mathrm{~Hz}, 6 \mathrm{H}) ;{ }^{13} \mathrm{C}$ NMR $\left(101 \mathrm{MHz}, \mathrm{DMSO}-\mathrm{d}_{6}\right) \delta 152.8,141.2,139.2,133.4,132.8,132.2$, 129.5, 70.4, 59.9, 57.3, 54.8, 51.9, 32.0, 31.6, 29.4, 29.3, 29.0, 28.9, 28.4, 27.1, 22.4, 17.0, 15.0, 14.3, 12.6; LC/MS (Method B): Retention time $10.14 \mathrm{~min}, 938.56$ [M-H] $]^{+}$; HR-MS(ESI) calcd. for formula $\mathrm{C}_{41} \mathrm{H}_{67} \mathrm{BF}_{2} \mathrm{~N}_{3} \mathrm{O}_{10} \mathrm{~S}_{4}[\mathrm{M}-\mathrm{H}]^{+}$: 938.3770; Found: 938.3721. 


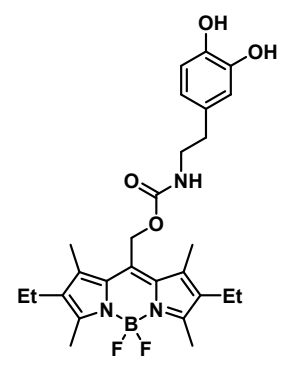

12
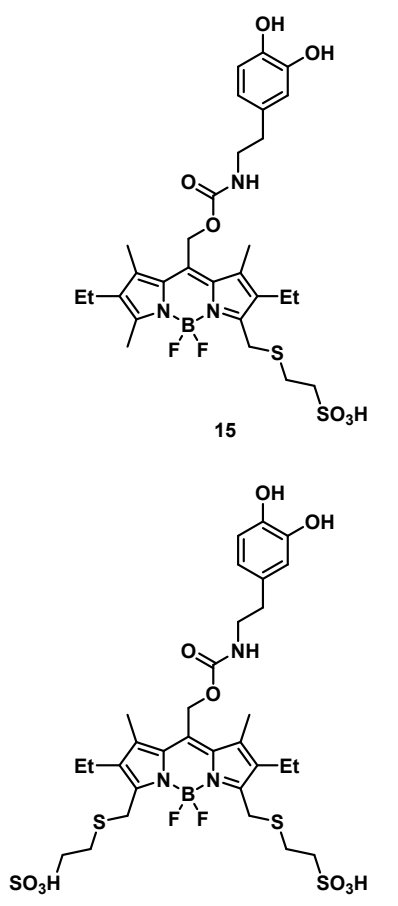

18

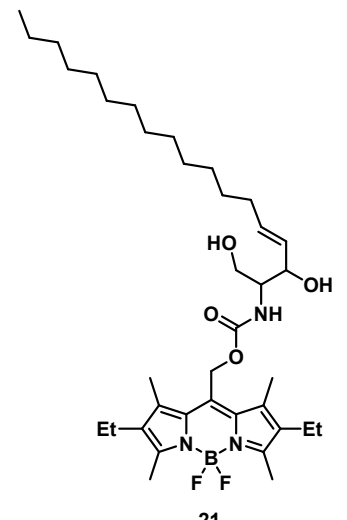

21

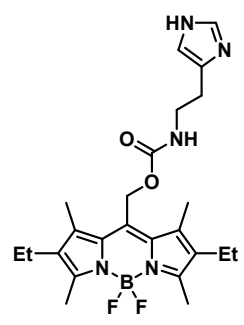

13

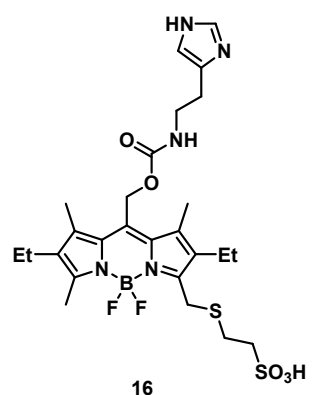

16

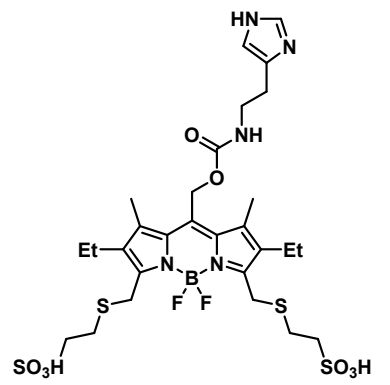

19
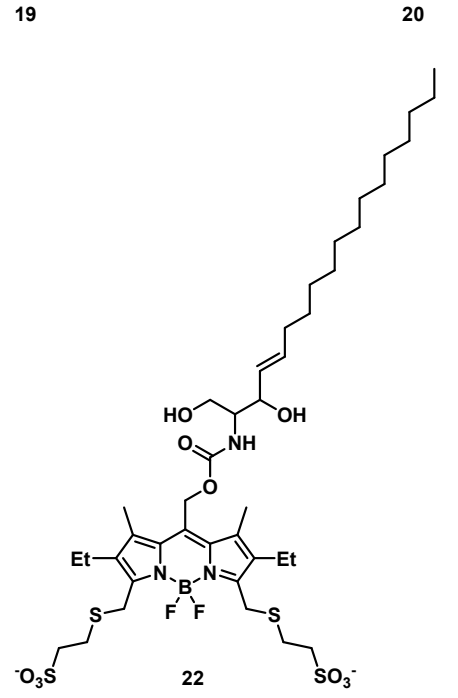

Figure S13:

Structures of BODIPY-photocaged bio-active molecules 12-22. 


\section{Photophysical and spectroscopic data}

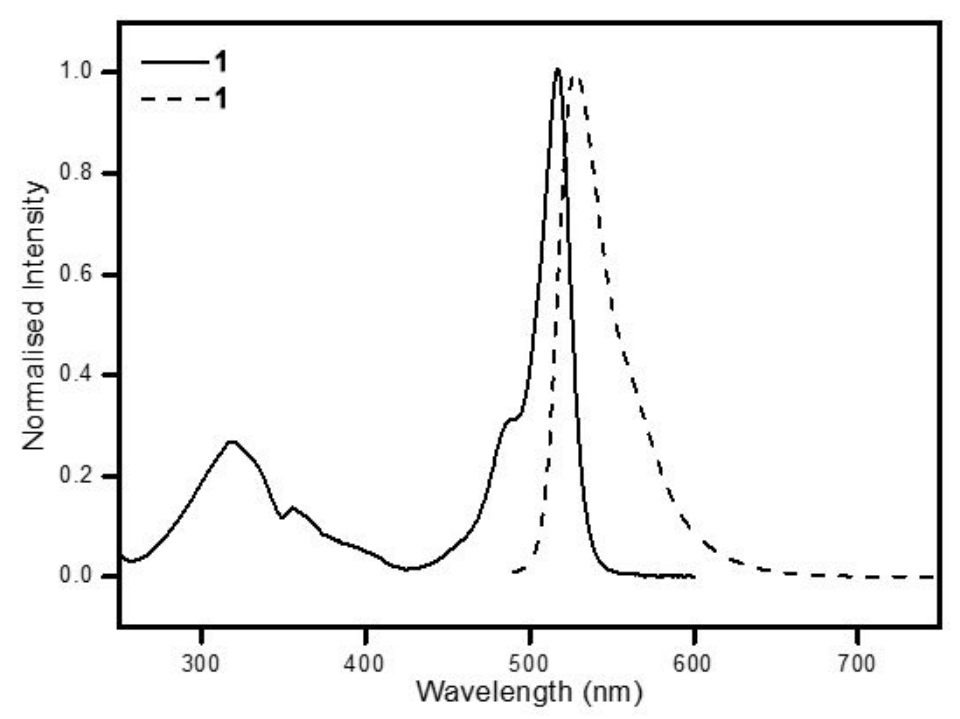

Figure S14:

Absorption (solid line) and normalized emission spectrum of BODIPY 1 (dashed line; excitation wavelength: $480 \mathrm{~nm}$ ) in $(7 / 3) \mathrm{CH}_{3} \mathrm{CN} /$ water. $\left(c \sim 1 \times 10^{-5} \mathrm{M}\right)$.
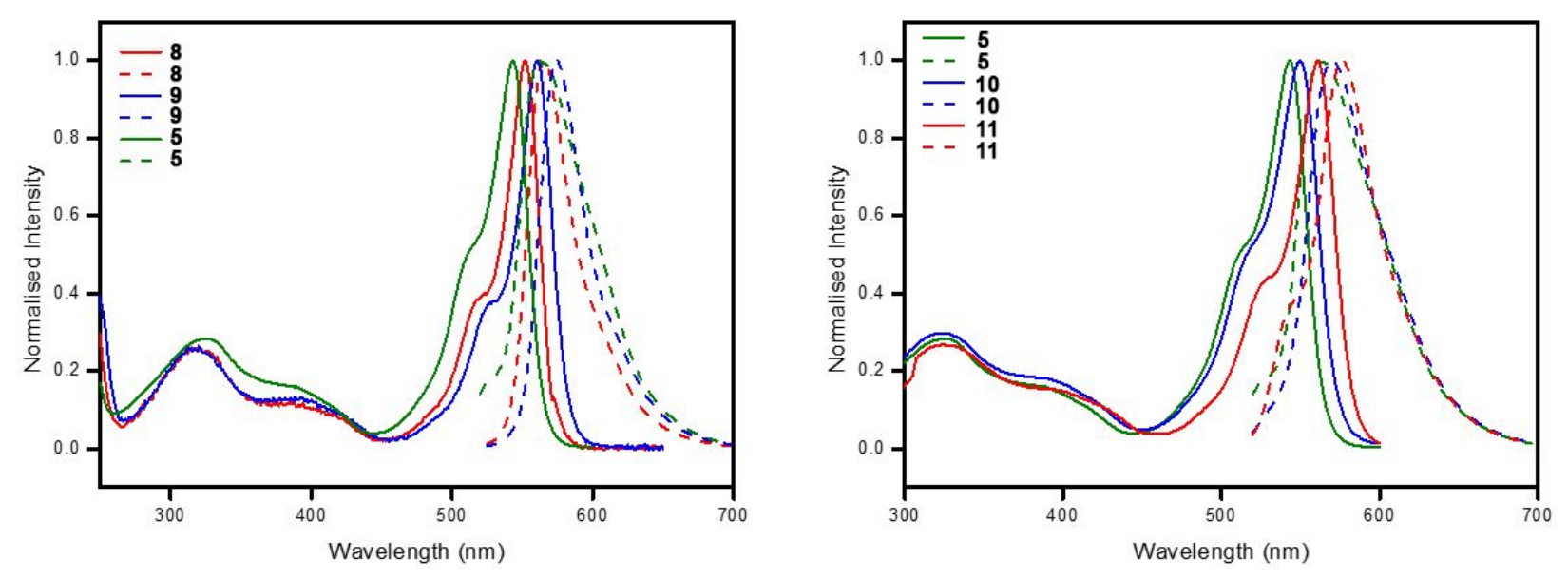

Figure S15:

Absorption (solid line) and normalized emission spectrum of BODIPYs 5 and 8-11 (dashed line; excitation wavelength: $480 \mathrm{~nm})$ in $(7 / 3) \mathrm{CH}_{3} \mathrm{CN} /$ water. $\left(c \sim 1 \times 10^{-5} \mathrm{M}\right)$. 


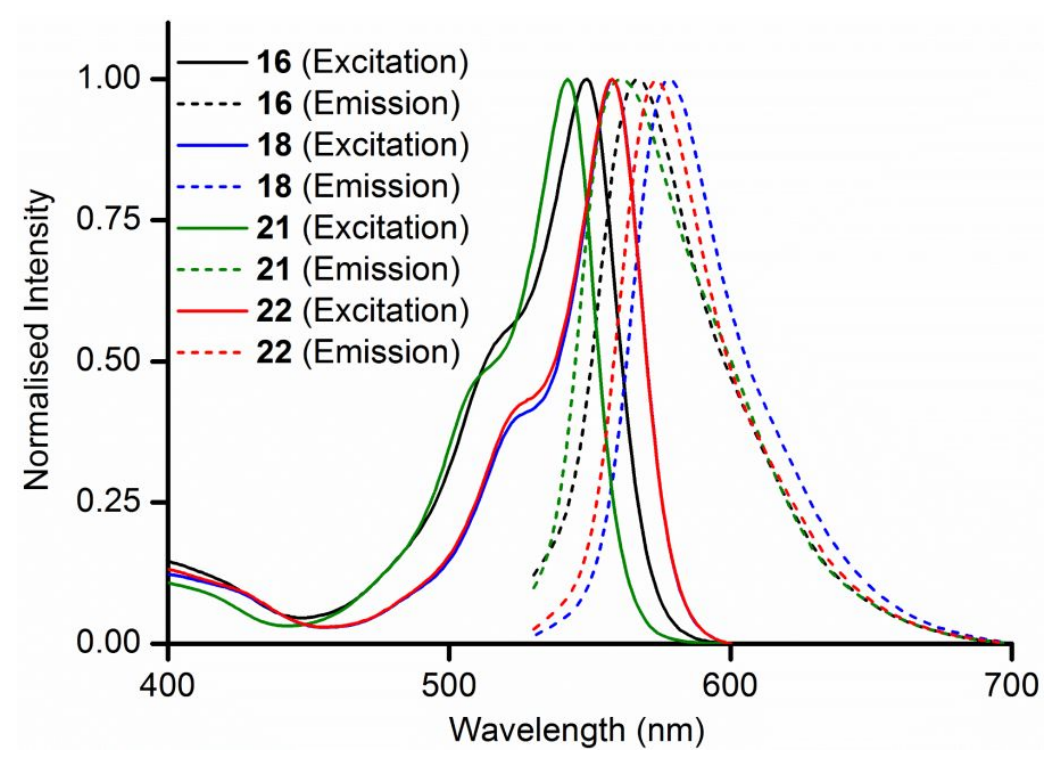

Figure S16:

Absorption (solid line) and normalized emission spectrum of BODIPYs 16, 18, 21 and 22 (dashed line; excitation wavelength: $480 \mathrm{~nm})$ in $(7 / 3) \mathrm{CH}_{3} \mathrm{CN} /$ water. $\left(c \sim 1 \times 10^{-5} \mathrm{M}\right)$. 

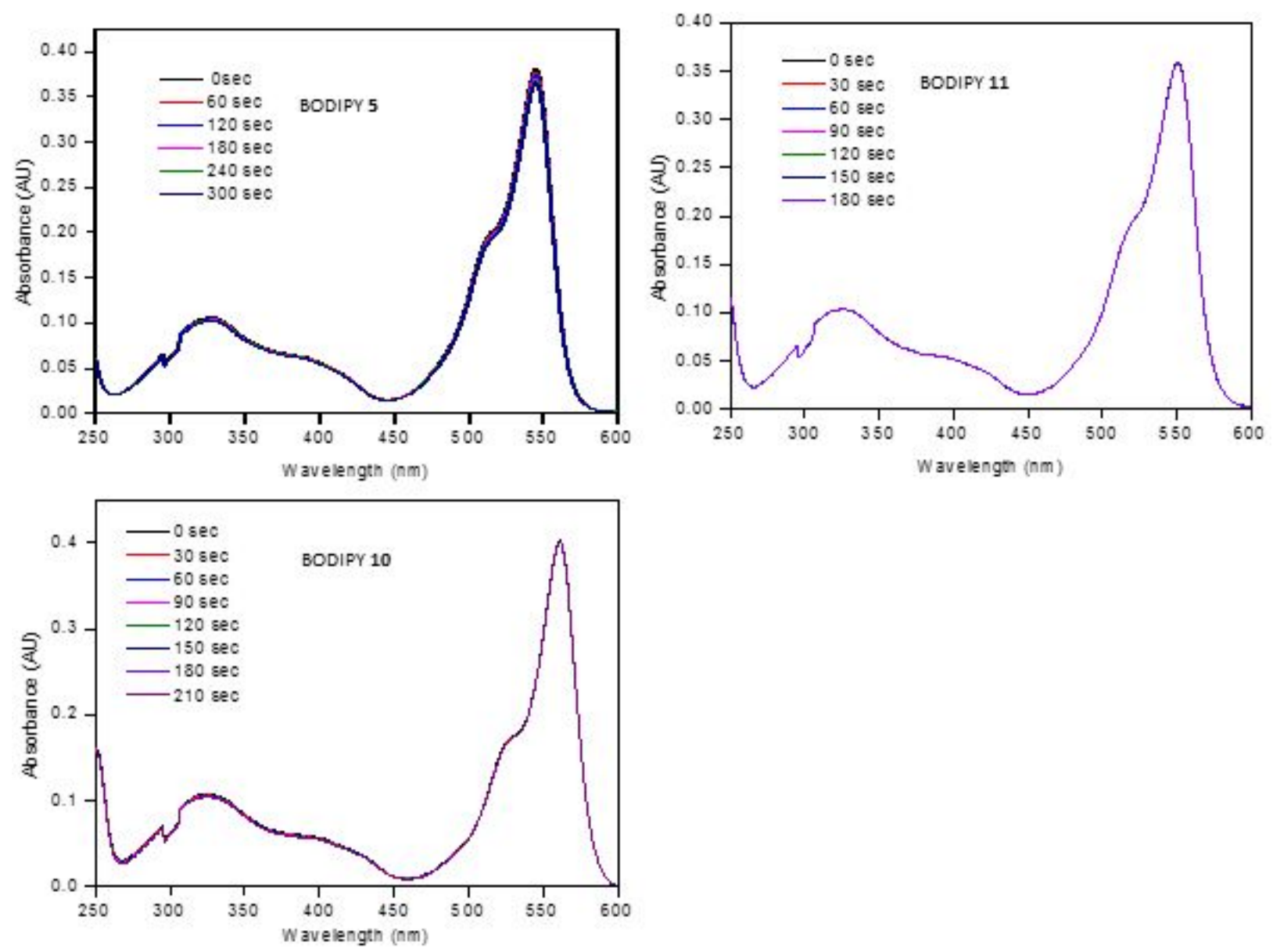

Figure S17:

UV-Vis spectra for stability in dark of BODIPYs 5,10 and $11.10 \mu \mathrm{M}$ of each compound was separately kept in dark in $\mathrm{CH}_{3} \mathrm{CN} /$ water $(7 / 3)$ for the indicated times and spectra were acquired. 

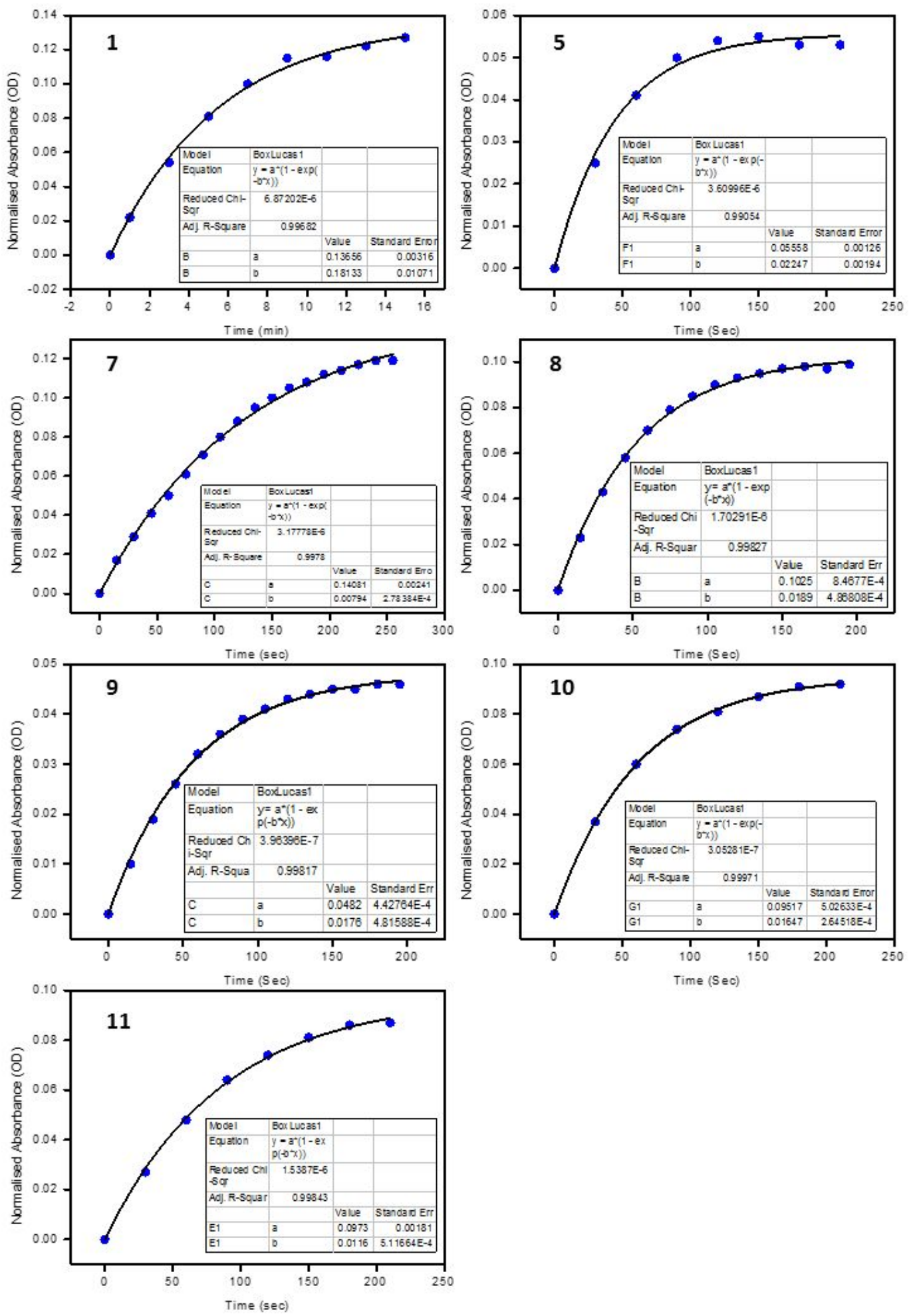

Figure S18:

Kinetics graphs for rate constant, $(k)$ of BODIPYs 1, 5, and 7-11. $10 \mu \mathrm{M}$ of each compound was separately irradiated with $545 / 30 \mathrm{~nm}\left(49 \mathrm{~mW} / \mathrm{cm}^{2}\right)$ (except 1: $\left.520 / 30 \mathrm{~nm} ; 49 \mathrm{~mW} / \mathrm{cm}^{2}\right)$ light in $\mathrm{CH}_{3} \mathrm{CN} /$ water $(7 / 3)$ for the indicated times. Normalised absorbance $\left(\mathrm{A}-\mathrm{A}_{0}\right)$ at $380 \mathrm{~nm} V s$ time were plotted. 


\section{Computation methods and data}

All calculations were performed using the Gaussian 09 software package ${ }^{4}$ utilizing the B3LYP functional ${ }^{5-7}$ and 6$31+\mathrm{G}(\mathrm{d}, \mathrm{p})$ polarized double- $\zeta$ basis set. In all cases, optimized geometries were found to have zero imaginary frequencies and corrections for the zero-point vibrational energy and thermal energy were added unscaled. When multiple rotamers were possible, the lowest energy rotamer was used. When not denoted, calculations were performed in the gas-phase at the default temperature $(298.15 \mathrm{~K})$. Where noted, the SMD solvent model $^{8}$ was used with water as the solvent.

For computing the energy of singlet state structures, an unrestricted broken-symmetry approach to computing the singlet states was used for B3LYP calculations. Unfortunately, this approach using DFT very frequently suffers from considerable spin contamination when there is also a low-energy triplet state, which is indicated by $\left\langle S^{2}\right\rangle$ values greater than zero. In these cases, the following equation was used to titrate out contamination from a low-energytriplet state and determine a spin-purified energy of the singlet state. ${ }^{9-12}$

$$
E_{\text {singlet }}=\frac{2 E_{\left\langle S_{Z}\right\rangle=0}-\left\langle S^{2}\right\rangle E_{\left\langle S_{Z}\right\rangle=1}}{2-\left\langle S^{2}\right\rangle}
$$

where $\mathrm{E}_{\text {singlet }}$ is the corrected singlet energy, $E_{\left\langle S_{z}\right\rangle=0}$ is the broken-symmetry energy, $\left\langle S^{2}\right\rangle$ is the expectation value of the total-spin operator for the broken-symmetry calculation (anywhere from about zero to one), and $E_{\left\langle S_{Z}\right\rangle=1}$ is the energy of the triplet state at the singlet geometry.

Calculation of the $\mathrm{C}-\mathrm{O}$ bond breaking energy was accomplished by performing a relaxed potential energy scan on the triplet state by increasing the $\mathrm{C}-\mathrm{O}$ bond length by $0.1 \AA$. The bond breaking energy was then computed by calculating the difference between the SCF Energy of the structure with the intact C-O bond (reactant) and the highest energy structure in the scan (transition). The B3LYP functional, 6-31+G(d,p) polarized double- $\zeta$ basis set, and SMD solvent model with water as the solvent were utilized for these calculations.

The $\sigma_{\mathrm{p}}$ Hammett parameters were used directly from the work of H. Hansch, A. Leo and D. Hoekman. ${ }^{13}$ 

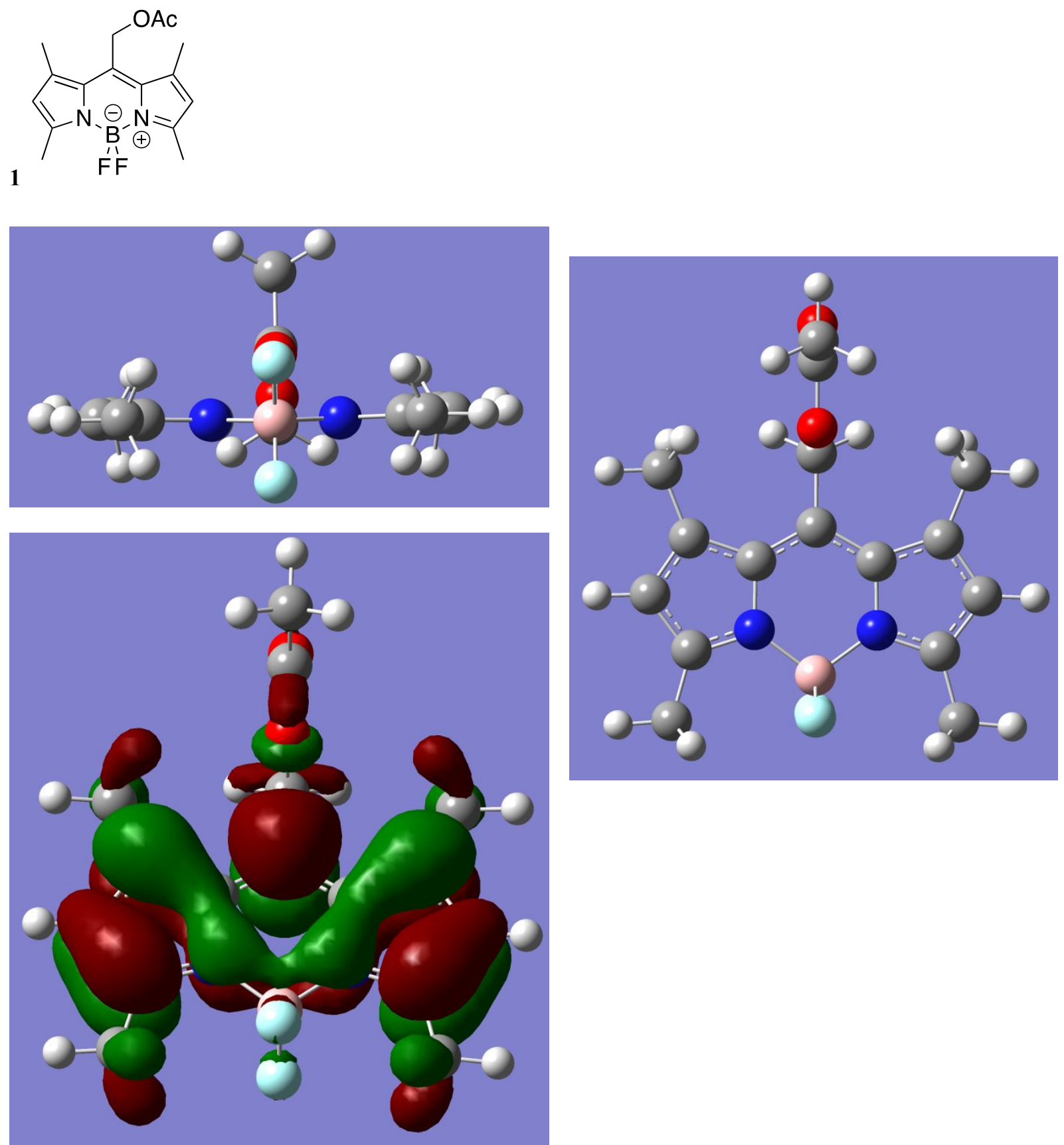

\section{Computation S1:}

Side view and top view of singlet state, gas-phase optimized structure 1, as well as the LUMO for $\mathbf{1}$. 

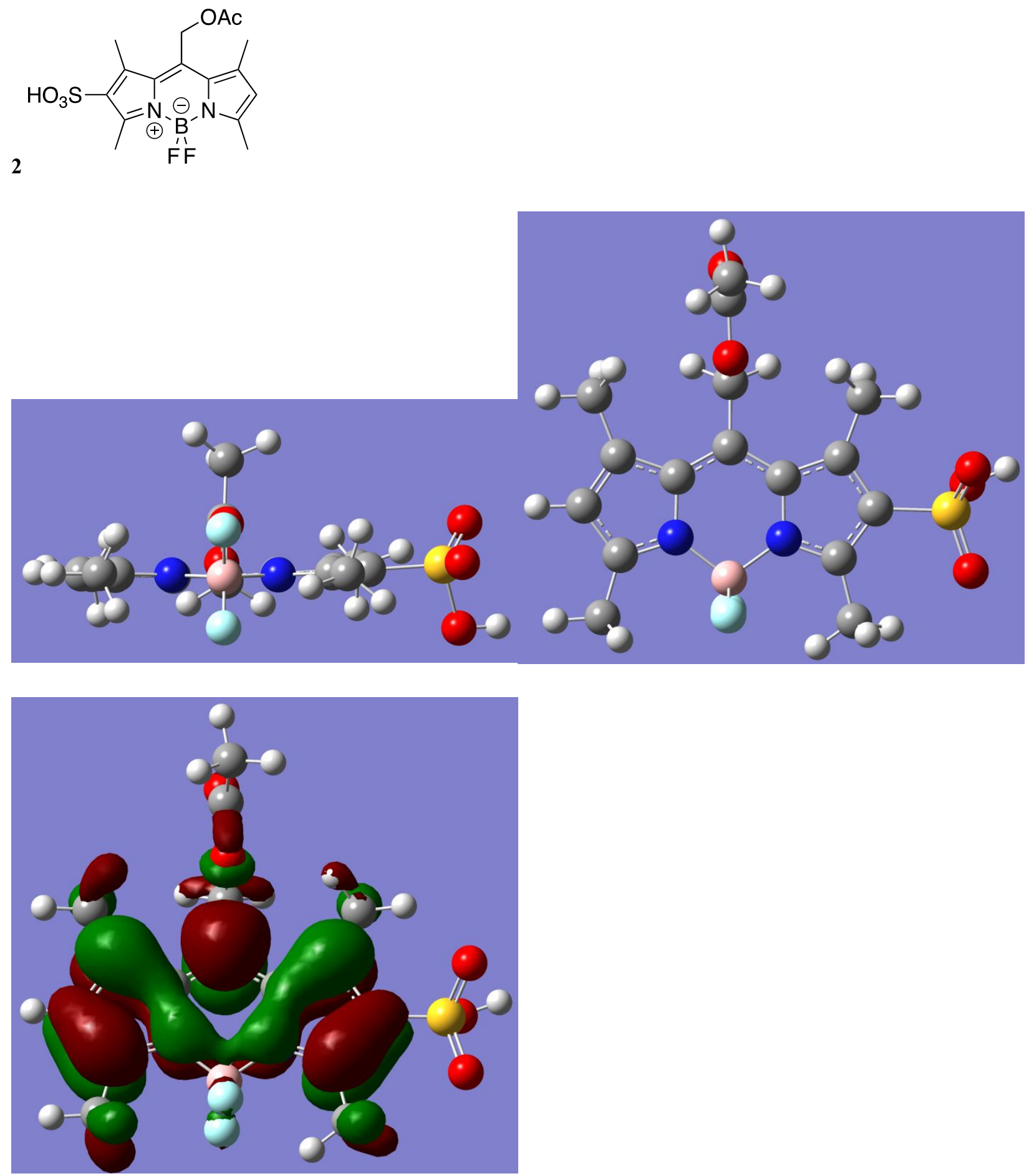

\section{Computation S2:}

Side view and top view of singlet state, gas-phase optimized structure $\mathbf{2}$, as well as the LUMO for $\mathbf{2}$ 
<smiles></smiles>
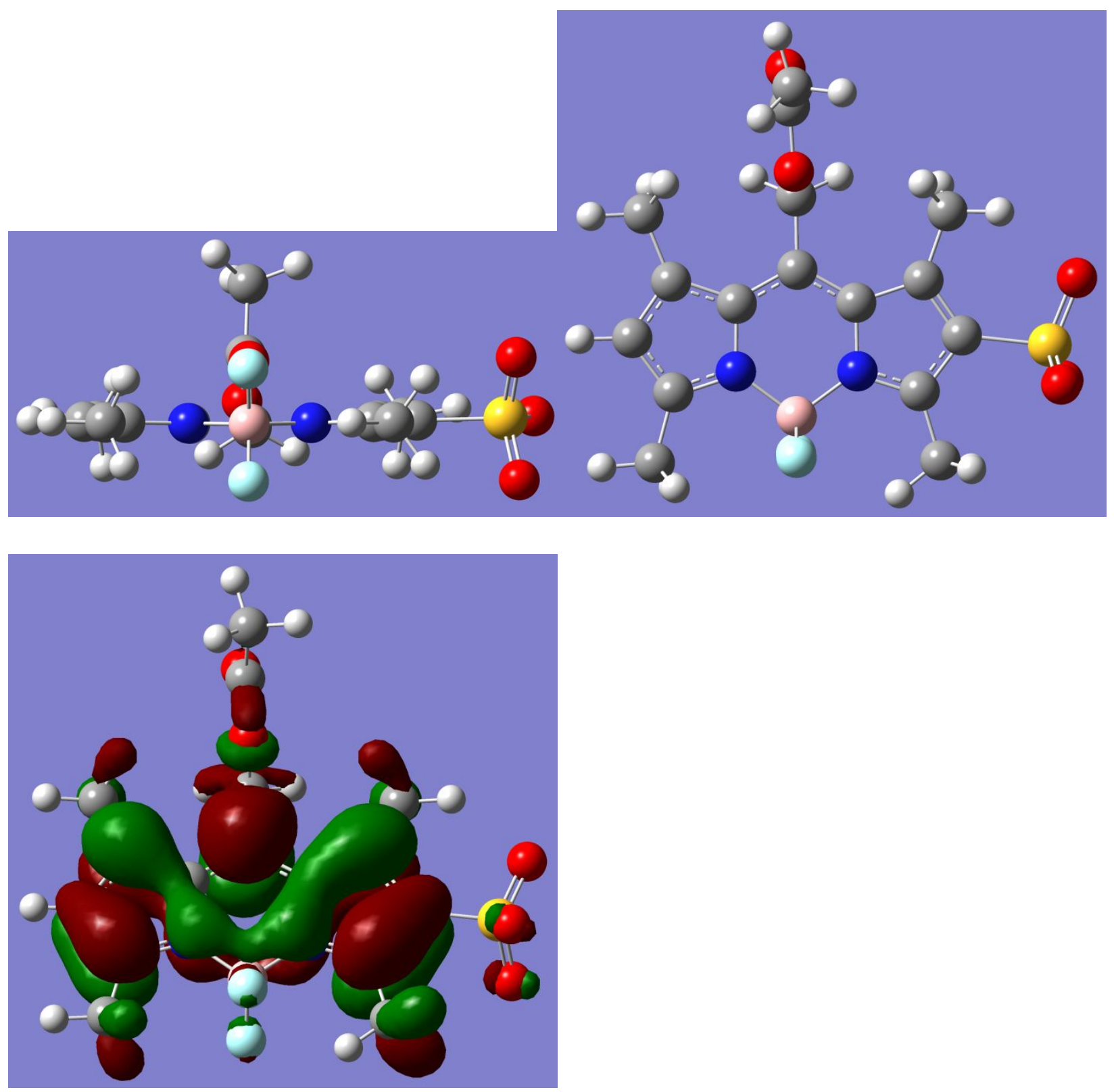

\section{Computation S3:}

Side view and top view of singlet state, gas-phase optimized structure $\mathbf{2}$ in its anion form, as well as the LUMO for $\mathbf{2}$ in its anion form. 
<smiles></smiles>
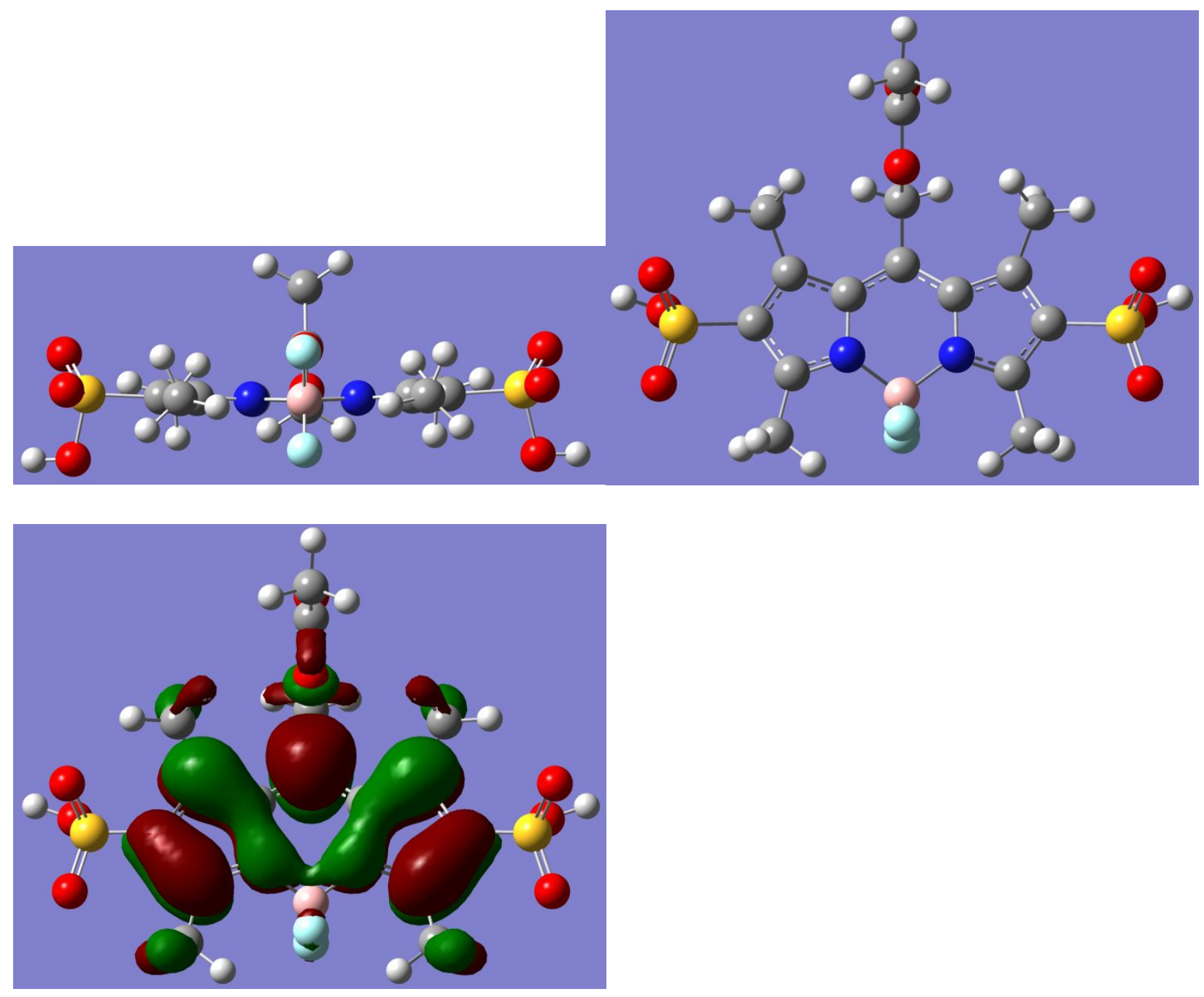

\section{Computation S4:}

Side view and top view of singlet state, gas-phase optimized structure $\mathbf{3}$, as well as the LUMO for $\mathbf{3}$. 
<smiles></smiles>
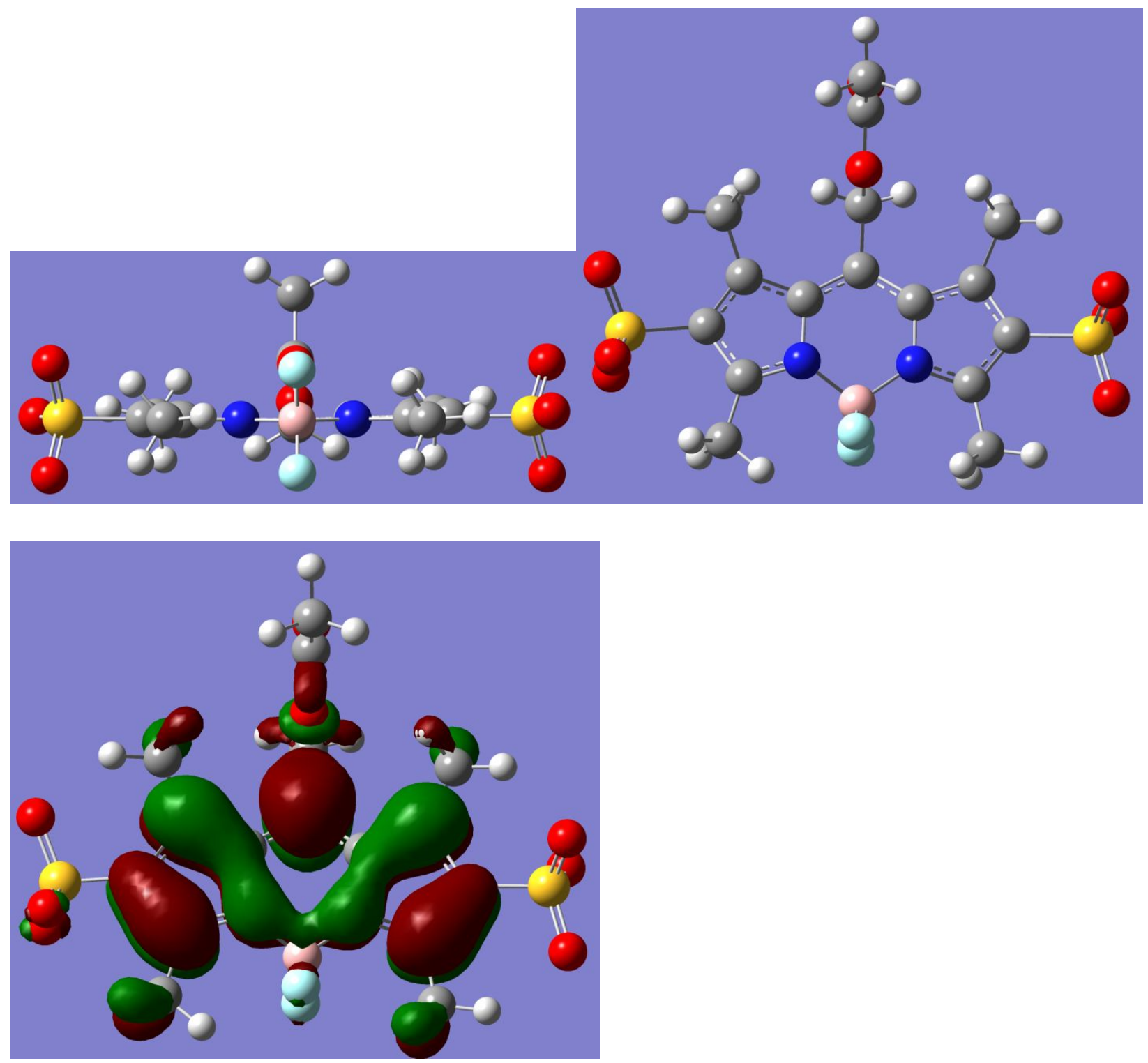

\section{Computation S5:}

Side view and top view of singlet state, gas-phase optimized structure $\mathbf{3}$ in its anion form, as well as the LUMO for $\mathbf{3}$ in its anion form. 

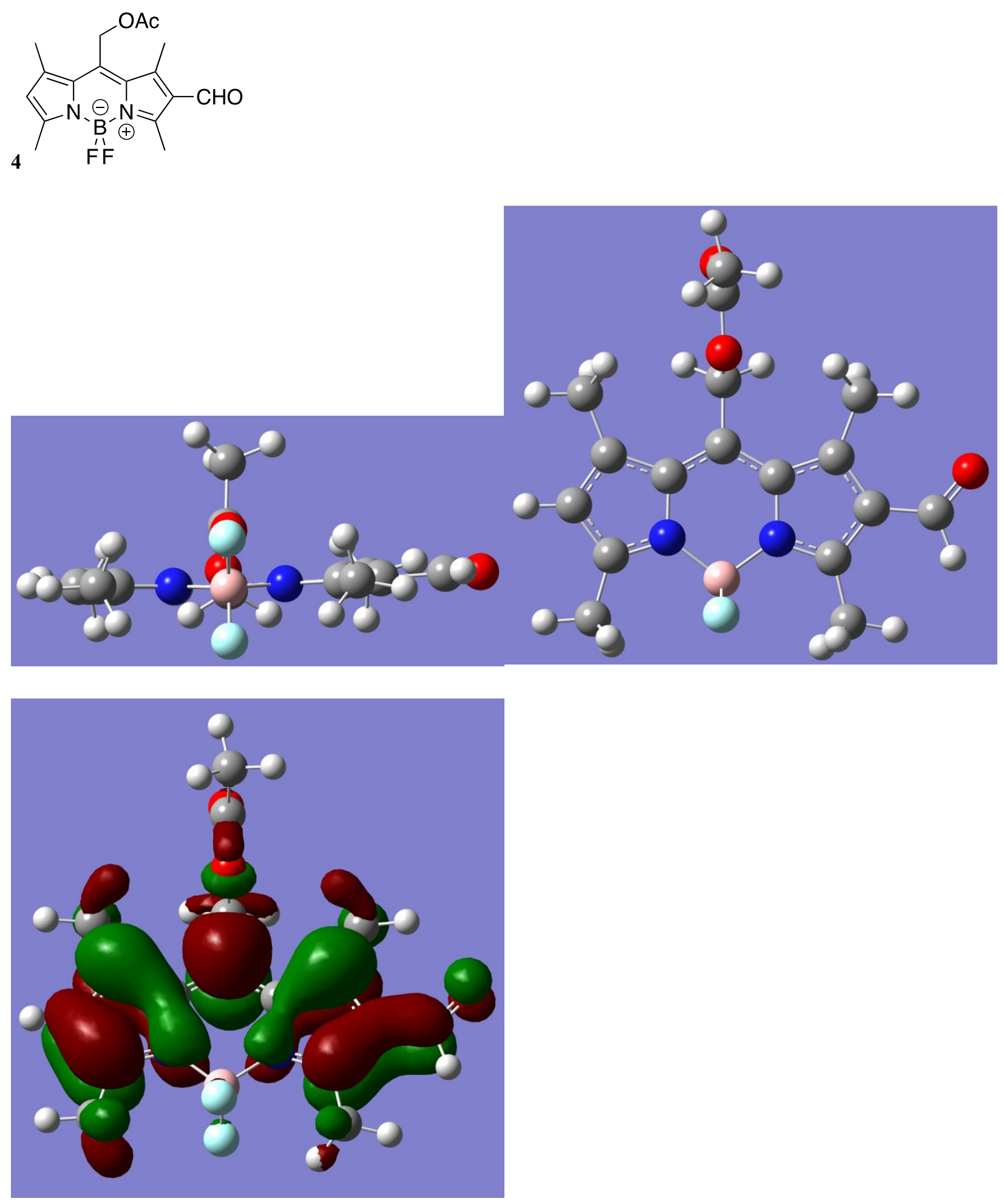

\section{Computation S6:}

Side view and top view of singlet state, gas-phase optimized structure 4, as well as the LUMO for 4. 

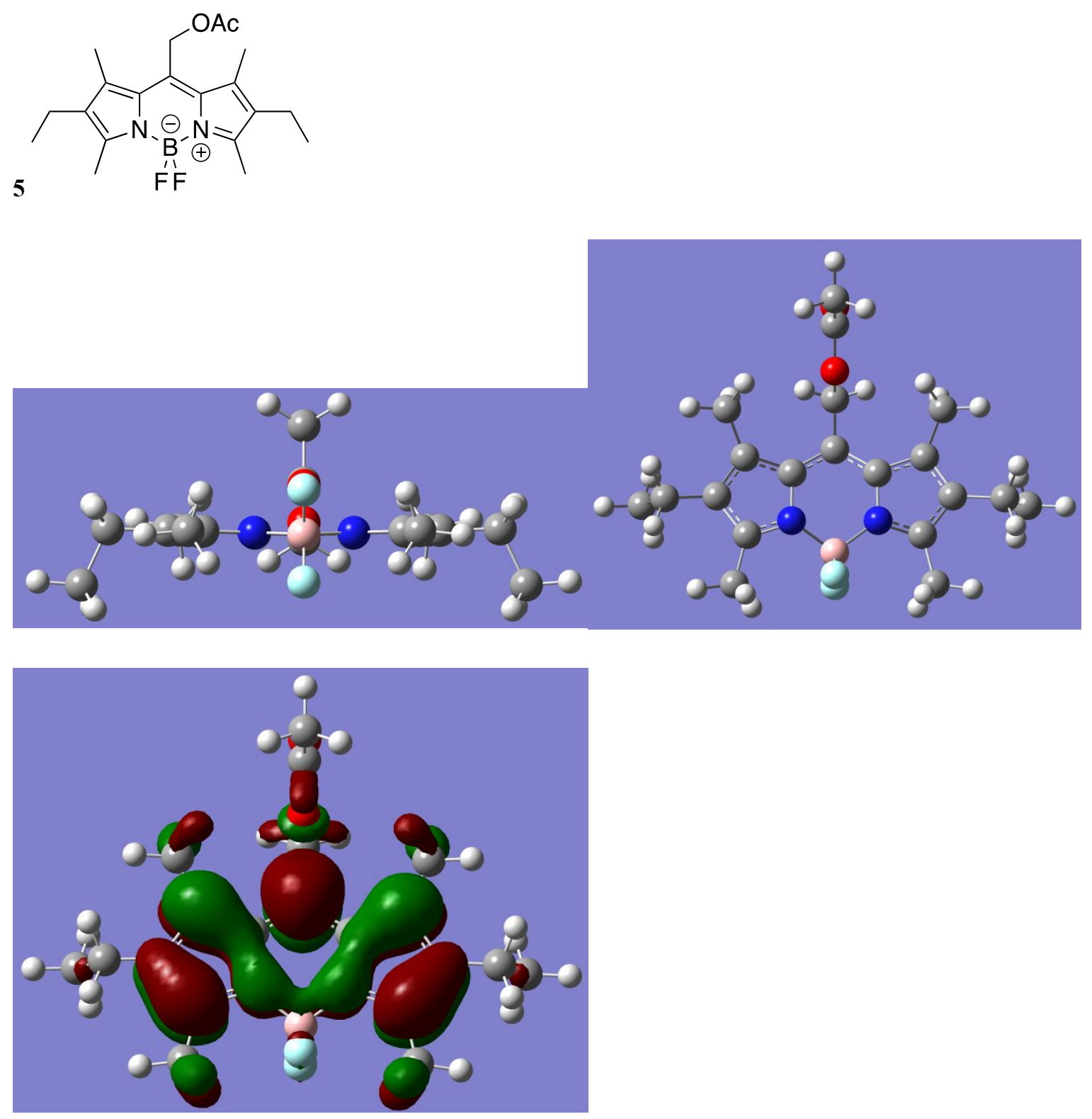

\section{Computation S7:}

Side view and top view of singlet state, gas-phase optimized structure $\mathbf{5}$, as well as the LUMO for $\mathbf{5}$. 
<smiles>CC(=O)OCC1=C2C=C(N)C=[N+]2B(F)n2cc(N)cc21</smiles>

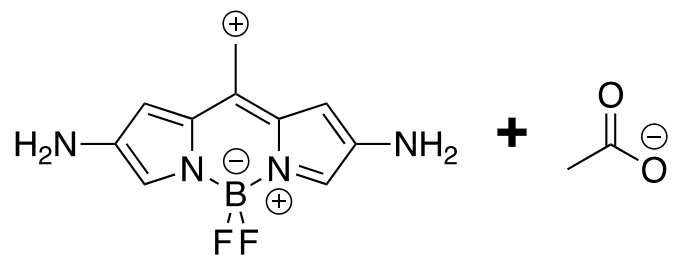

\section{Computation S8a:}

Reaction modeled using B3LYP/6-31+G(d,p) and $\mathrm{SMD}=$ water. $\Delta \Delta \mathrm{G}$ determined from the optimized energies of the BODIPY structure triplet states and the optimized energy of the acetate structure singlet state.

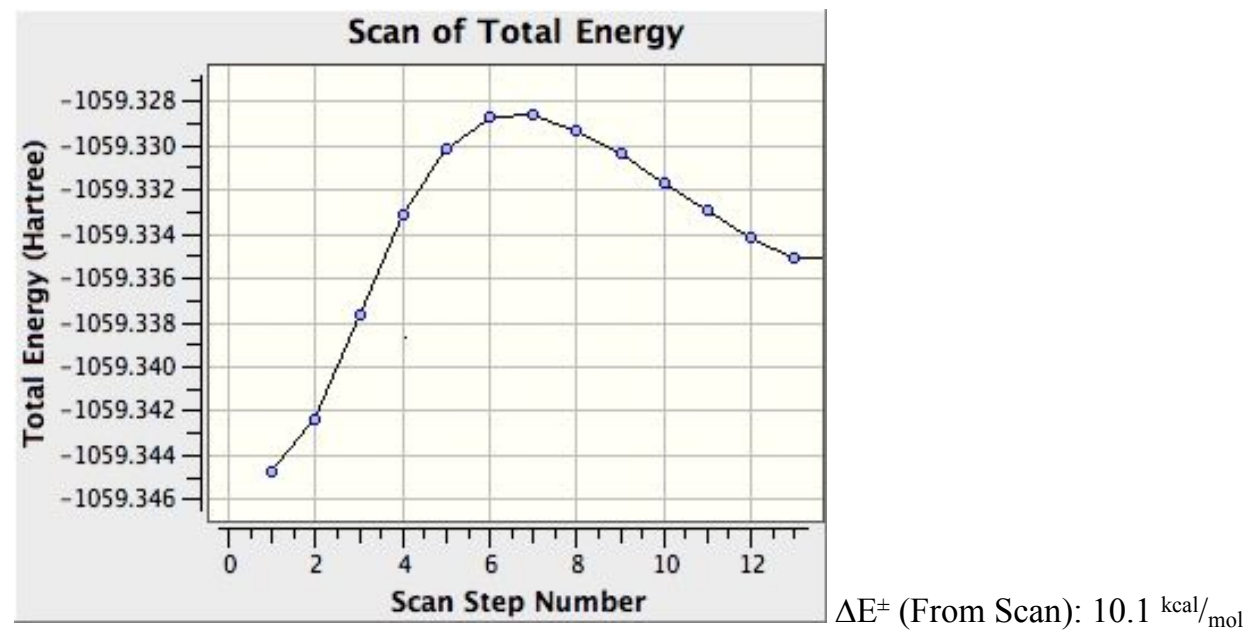

\section{Computation S8b:}

Graph generated by the relaxed potential energy scan of the $\mathrm{C}-\mathrm{O}$ bond breaking on the triplet state modeled using B3LYP/6-31+G(d,p) and SMD = water for the reaction in Computation S8a. 
<smiles>CC(=O)OCC1=C2C=C(O)C=C2B(F)[B-](F)(F)n2cc(O)cc21</smiles><smiles>CO[Mg]O[Mg]</smiles><smiles></smiles>

\section{Computation S9a:}

Reaction modeled using B3LYP/6-31+G(d,p) and $\mathrm{SMD}=$ water. $\Delta \Delta \mathrm{G}$ determined from the optimized energies of the BODIPY structure triplet states and the optimized energy of the acetate structure singlet state.

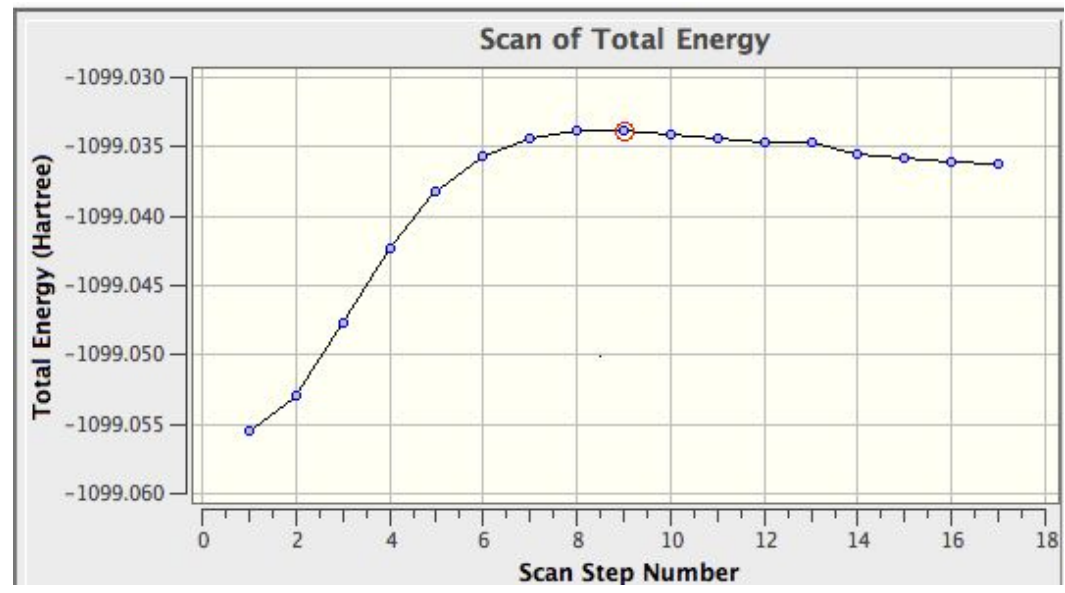

$\Delta \mathrm{E}^{ \pm}$(From Scan): $13.6^{\mathrm{kcal} / \mathrm{mol}}$

\section{Computation S9b:}

Graph generated by the relaxed potential energy scan of the C-O bond breaking on the triplet state modeled using B3LYP/6-31+G(d,p) and SMD = water for the reaction in Computation S9a. 
<smiles>CCC1=CN2c3cc(CC)cn3B(F)[B-]2(F)C(COC(C)=O)=C1</smiles><smiles></smiles>

\section{Computation S10a:}

Reaction modeled using B3LYP/6-31+G(d,p) and $\mathrm{SMD}=$ water. $\Delta \Delta \mathrm{G}$ determined from the optimized energies of the BODIPY structure triplet states and the optimized energy of the acetate structure singlet state.

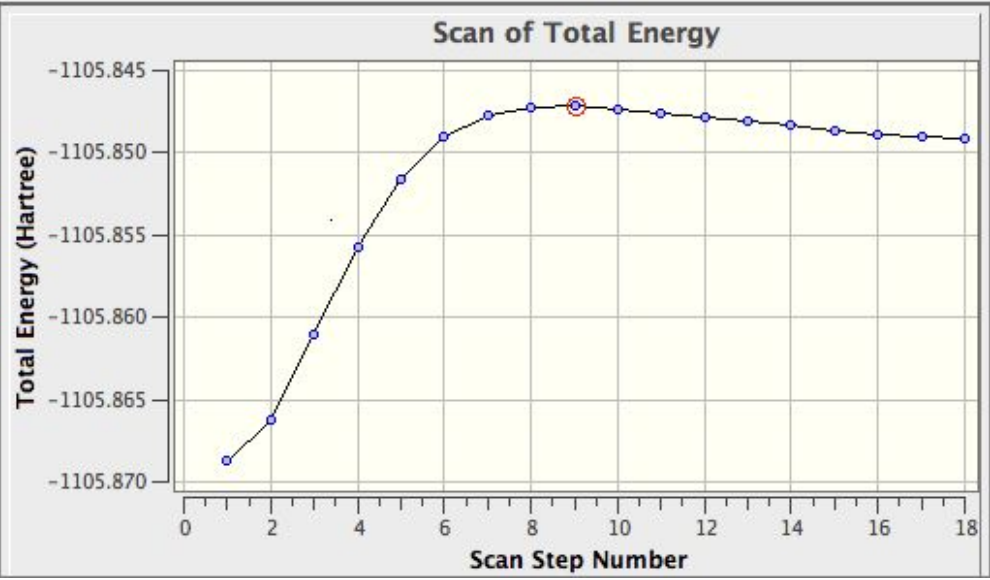

$$
\Delta \mathrm{E}^{ \pm} \text {(From Scan): } 13.5 \mathrm{kcal} / \mathrm{mol}
$$

\section{Computation S10b:}

Graph generated by the relaxed potential energy scan of the C-O bond breaking on the triplet state modeled using B3LYP/6-31+G(d,p) and SMD = water for the reaction in Computation 10a. 

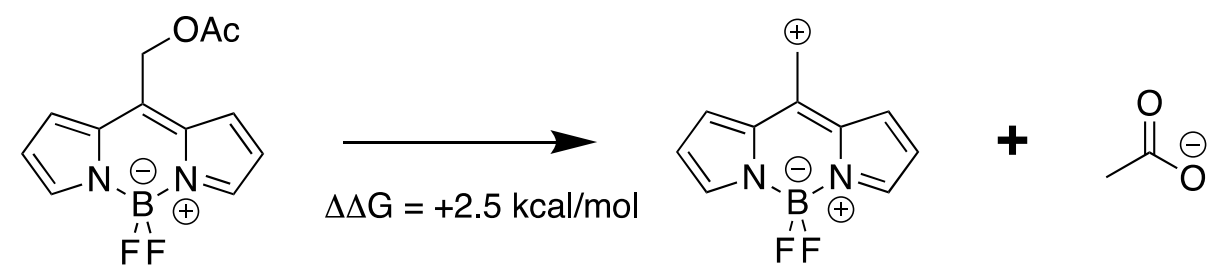

\section{Computation S11a:}

Reaction modeled using B3LYP/6-31+G(d,p) and SMD = water. $\Delta \Delta \mathrm{G}$ determined from the optimized energies of the BODIPY structure triplet states and the optimized energy of the acetate structure singlet state.

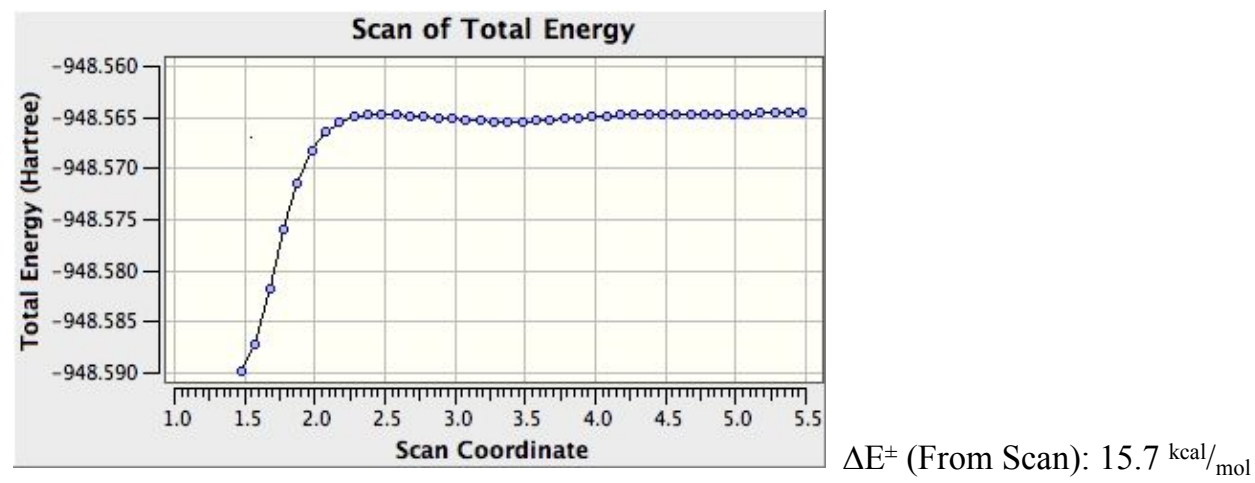

\section{Computation S11b:}

Graph generated by the relaxed potential energy scan of the C-O bond breaking on the triplet state modeled using B3LYP/6-31+G(d,p) and SMD = water for the reaction in Computation S11a. 


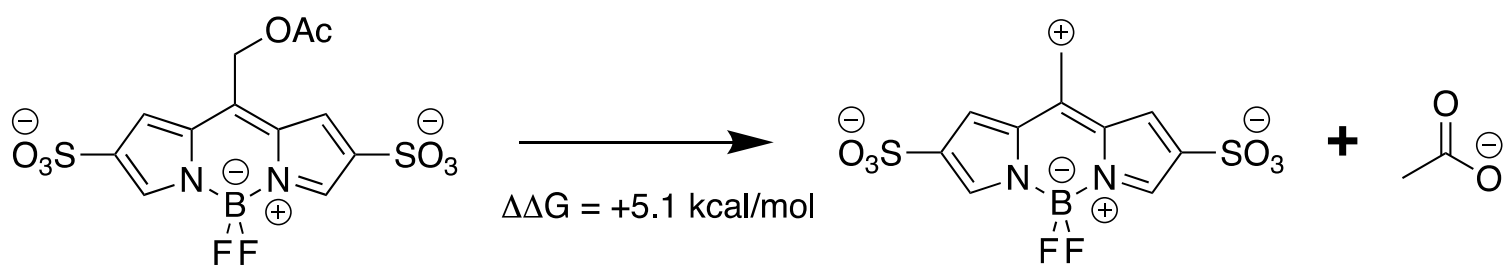

\section{Computation S12a:}

Reaction modeled using B3LYP/6-31+G(d,p) and SMD = water. $\Delta \Delta \mathrm{G}$ determined from the optimized energies of the BODIPY structure triplet states and the optimized energy of the acetate structure singlet state.

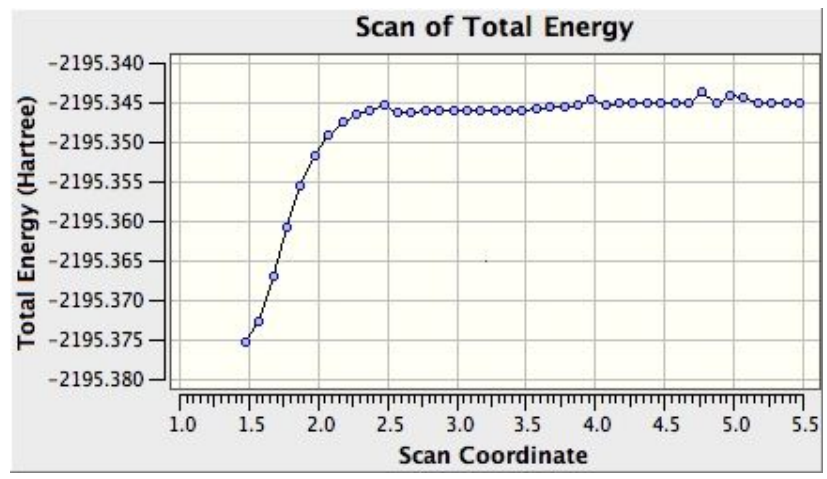

$\Delta \mathrm{E}^{ \pm}$(From Scan): $18.9 \mathrm{kcal} / \mathrm{mol}$

\section{Computation S12b:}

Graph generated by the relaxed potential energy scan of the $\mathrm{C}-\mathrm{O}$ bond breaking on the triplet state modeled using B3LYP/6-31+G(d,p) and SMD = water for the reaction in Computation S12a. 
<smiles></smiles>

\section{Computation S13a:}

Reaction modeled using B3LYP/6-31+G(d,p) and $\mathrm{SMD}=$ water. $\Delta \Delta \mathrm{G}$ determined from the optimized energies of the BODIPY structure triplet states and the optimized energy of the acetate structure singlet state.

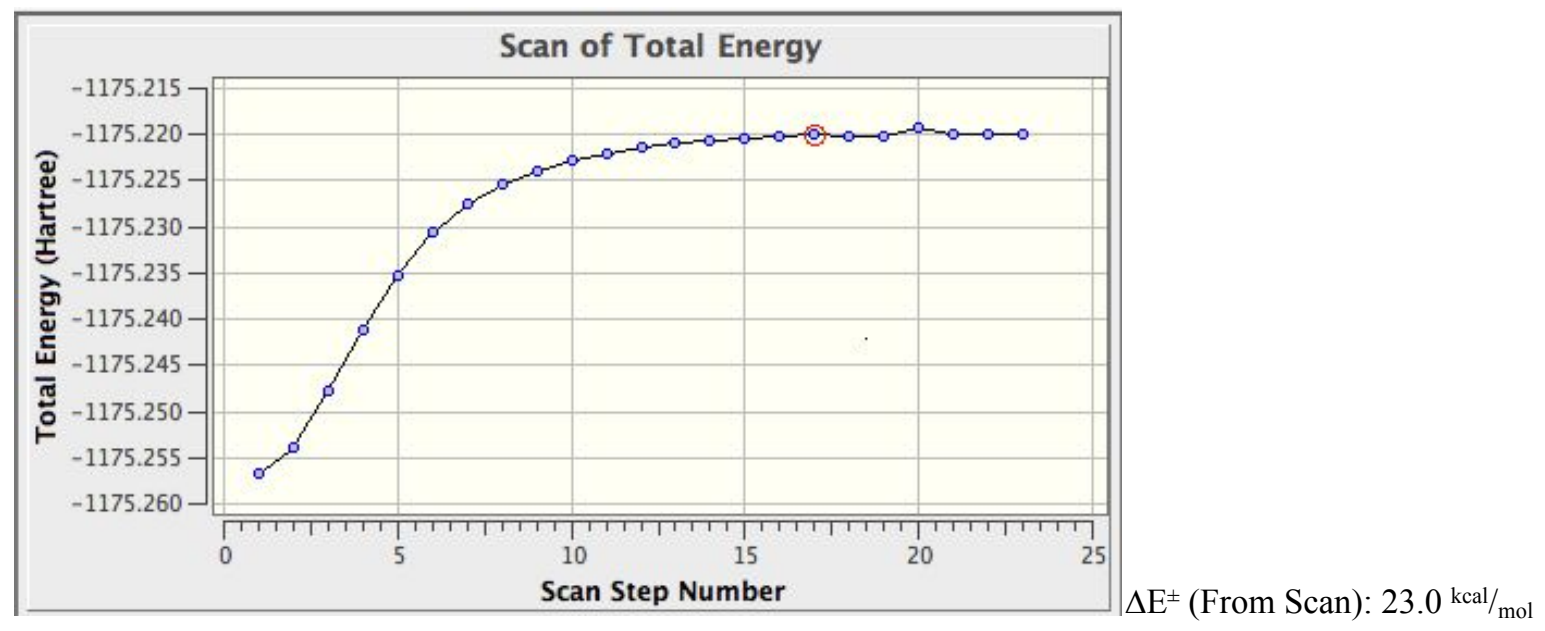

\section{Computation S13b:}

Graph generated by the relaxed potential energy scan of the $\mathrm{C}-\mathrm{O}$ bond breaking on the triplet state modeled using B3LYP/6-31+G(d,p) and SMD = water for the reaction in Computation S13a. 


\section{Cartesian Coordinates}

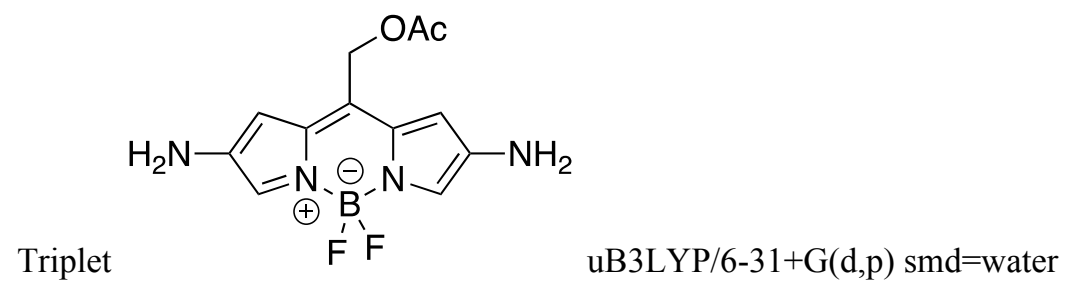

$\begin{array}{lrrr}\text { C } & 0.88796700 & 3.37327600 & -0.13038800 \\ \mathrm{C} & 1.98604600 & 2.50793400 & 0.15410600 \\ \mathrm{C} & 0.20755900 & 1.22108400 & -0.31694800 \\ \mathrm{C} & -0.49033500 & 0.00729900 & -0.51697400 \\ \mathrm{C} & 0.18574800 & -1.22403800 & -0.32154300 \\ \mathrm{C} & -0.22155300 & 2.55850400 & -0.42073600 \\ \mathrm{C} & -1.93060400 & 0.01983400 & -0.88723800 \\ \mathrm{C} & 1.94605100 & -2.53837800 & 0.15114400 \\ \mathrm{C} & -0.26784100 & -2.54724400 & -0.42793800 \\ \mathrm{C} & 0.83032600 & -3.38477400 & -0.13555900 \\ \mathrm{~B} & 2.44083800 & -0.01908600 & 0.27269100 \\ \mathrm{~F} & 2.97068800 & -0.02613800 & 1.59532000 \\ \mathrm{~F} & 3.55760200 & -0.02881500 & -0.61218400 \\ \mathrm{~N} & 1.55101400 & -1.24576700 & 0.03879800 \\ \mathrm{~N} & 1.57065100 & 1.21932600 & 0.04114600 \\ \mathrm{H} & 3.00010600 & 2.76905800 & 0.42265300 \\ \mathrm{H} & -1.21650400 & 2.89422800 & -0.67513400 \\ \mathrm{H} & 2.95493800 & -2.81898900 & 0.41901500 \\ \mathrm{H} & -1.26788100 & -2.86683800 & -0.68235700 \\ \mathrm{~N} & 0.86717200 & -4.73419900 & -0.10791900 \\ \mathrm{H} & 1.73048300 & -5.22413200 & 0.08207900 \\ \mathrm{H} & 0.05263400 & -5.27800200 & -0.35699400 \\ \mathrm{~N} & 0.94238200 & 4.73197100 & -0.06973600 \\ \mathrm{H} & 0.18318000 & 5.26830600 & -0.46816500 \\ \mathrm{H} & 1.84752000 & 5.18314200 & -0.04793100 \\ \mathrm{H} & -2.20412200 & 0.91356600 & -1.45000300 \\ \mathrm{H} & -2.21619200 & -0.86149200 & -1.46365100 \\ \mathrm{O} & -2.74504600 & 0.01543600 & 0.35330600 \\ \mathrm{C} & -4.08009000 & 0.02787700 & 0.21079300 \\ \mathrm{O} & -4.63512700 & 0.04095100 & -0.88507400 \\ \mathrm{C} & -4.79145200 & 0.02571000 & 1.53329900 \\ \mathrm{H} & -5.86995100 & 0.02142400 & 1.37504900 \\ \mathrm{H} & -4.49663300 & -0.85522400 & 2.11185100 \\ \mathrm{H} & -4.50447100 & 0.91203000 & 2.10793400 \\ & & & \end{array}$

Sum of Electronic and Thermal Free Energies $=-1059.146365$ 
<smiles></smiles>

$\begin{array}{rrrr}\text { C } & 3.38547100 & 0.19211600 & 0.00008800 \\ \mathrm{C} & 2.51054300 & -0.95018700 & 0.00012600 \\ \mathrm{C} & 1.25061500 & 0.88943000 & 0.00000500 \\ \mathrm{C} & 0.00000000 & 1.63271200 & -0.00006700 \\ \mathrm{C} & -1.25061500 & 0.88943000 & 0.00000400 \\ \mathrm{C} & 2.56024200 & 1.34110500 & 0.00002600 \\ \mathrm{C} & 0.00000000 & 2.99701300 & -0.00015400 \\ \mathrm{C} & -2.51054300 & -0.95018700 & 0.00012500 \\ \mathrm{C} & -2.56024200 & 1.34110500 & 0.00002500 \\ \mathrm{C} & -3.38547100 & 0.19211600 & 0.00008800 \\ \mathrm{~B} & 0.00000000 & -1.44509200 & -0.00007200 \\ \mathrm{~F} & 0.00000000 & -2.26330800 & 1.14421700 \\ \mathrm{~F} & 0.00000000 & -2.26287600 & -1.14472700 \\ \mathrm{~N} & -1.24398900 & -0.52172300 & 0.00006700 \\ \mathrm{~N} & 1.24398900 & -0.52172300 & 0.00006800 \\ \mathrm{H} & 2.77677500 & -1.99867600 & 0.00019400 \\ \mathrm{H} & 2.89474600 & 2.36775200 & 0.00000400 \\ \mathrm{H} & -2.77677500 & -1.99867600 & 0.00019300 \\ \mathrm{H} & -2.89474600 & 2.36775200 & 0.00000300 \\ \mathrm{~N} & -4.72210500 & 0.11550900 & 0.00016900 \\ \mathrm{H} & -5.18903500 & -0.78327500 & 0.00002500 \\ \mathrm{H} & -5.29023100 & 0.95377700 & -0.00002300 \\ \mathrm{~N} & 4.72210500 & 0.11550900 & 0.00016800 \\ \mathrm{H} & 5.29023100 & 0.95377700 & -0.00002400 \\ \mathrm{H} & 5.18903500 & -0.78327500 & 0.00002400 \\ \mathrm{H} & 0.92581200 & 3.56052500 & -0.00016800 \\ \mathrm{H} & -0.92581200 & 3.56052500 & -0.00016800\end{array}$

Sum of Electronic and Thermal Free Energies $=-830.520936$ 
<smiles></smiles>

$\begin{array}{lrrr}\text { C } & 3.35561900 & 0.17861300 & -0.31053300 \\ \mathrm{C} & 2.48114700 & -0.96674600 & -0.21262800 \\ \mathrm{C} & 1.25228400 & 0.87209600 & 0.04907400 \\ \mathrm{C} & -0.00000200 & 1.60699900 & 0.24428200 \\ \mathrm{C} & -1.25228800 & 0.87209600 & 0.04908500 \\ \mathrm{C} & 2.54516000 & 1.32909300 & -0.14033700 \\ \mathrm{C} & -0.00000300 & 2.91930900 & 0.57758900 \\ \mathrm{C} & -2.48113400 & -0.96674600 & -0.21269300 \\ \mathrm{C} & -2.54517600 & 1.32909000 & -0.14025900 \\ \mathrm{C} & -3.35561600 & 0.17861200 & -0.31053900 \\ \mathrm{~B} & 0.00000000 & -1.44564500 & 0.31493000 \\ \mathrm{~F} & 0.00000800 & -1.76952500 & 1.65797900 \\ \mathrm{~F} & -0.00000800 & -2.54993300 & -0.51113800 \\ \mathrm{~N} & -1.24040200 & -0.53451200 & -0.00376800 \\ \mathrm{~N} & 1.24040200 & -0.53451700 & -0.00377900 \\ \mathrm{H} & 2.72120100 & -2.01973000 & -0.27824100 \\ \mathrm{H} & 2.87238200 & 2.35695000 & -0.18937700 \\ \mathrm{H} & -2.72117500 & -2.01973000 & -0.27835700 \\ \mathrm{H} & -2.87240800 & 2.35694700 & -0.18924100 \\ \mathrm{~N} & -4.67825000 & 0.10925900 & -0.53326700 \\ \mathrm{H} & -5.15046300 & -0.77729500 & -0.64491300 \\ \mathrm{H} & -5.24578200 & 0.94386000 & -0.58481100 \\ \mathrm{~N} & 4.67825500 & 0.10926600 & -0.53326000 \\ \mathrm{H} & 5.24577300 & 0.94387300 & -0.58487000 \\ \mathrm{H} & 5.15048200 & -0.77728800 & -0.64484600 \\ \mathrm{H} & 0.92230000 & 3.46739600 & 0.72937200 \\ \mathrm{H} & -0.92230700 & 3.46739800 & 0.72935000\end{array}$

Uncorrected Sum of Electronic and Thermal Free Energies $=-830.422984$

Corrected Sum of Electronic and Thermal Free Energies $=-830.419121$ 


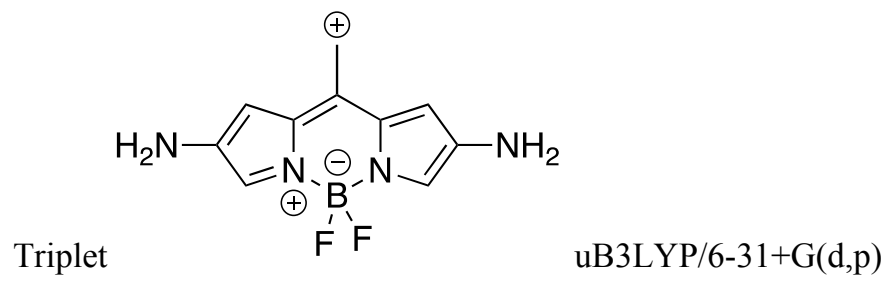

$\begin{array}{lrrr}\text { C } & 3.37472400 & 0.18786700 & -0.20854700 \\ \text { C } & 2.49353600 & -0.95700600 & -0.16412700 \\ \text { C } & 1.25075300 & 0.87573300 & 0.03689000 \\ \text { C } & -0.00001100 & 1.61034900 & 0.16015300 \\ \text { C } & -1.25074700 & 0.87569300 & 0.03688100 \\ \text { C } & 2.55926000 & 1.33227700 & -0.07643400 \\ \text { C } & -0.00001200 & 2.96106000 & 0.36743100 \\ \text { C } & -2.49356000 & -0.95702800 & -0.16409200 \\ \text { C } & -2.55926100 & 1.33224900 & -0.07638800 \\ \mathrm{C} & -3.37474000 & 0.18784900 & -0.20854300 \\ \text { B } & 0.00000700 & -1.46239800 & 0.21492100 \\ \text { F } & 0.00001900 & -1.90734400 & 1.52304000 \\ \text { F } & 0.00004600 & -2.49195500 & -0.70276500 \\ \text { N } & -1.24290100 & -0.53023400 & -0.02183500 \\ \text { N } & 1.24288400 & -0.53018800 & -0.02184200 \\ \text { H } & 2.73809200 & -2.00976400 & -0.22127200 \\ \text { H } & 2.89088200 & 2.35960600 & -0.09305200 \\ \text { H } & -2.73813400 & -2.00978200 & -0.22125100 \\ \text { H } & -2.89088000 & 2.35957800 & -0.09293700 \\ \text { N } & -4.70909000 & 0.11143600 & -0.35825200 \\ \text { H } & -5.18129200 & -0.77696200 & -0.44929400 \\ \text { H } & -5.28293100 & 0.94263500 & -0.37661800 \\ \text { N } & 4.70908000 & 0.11142900 & -0.35821900 \\ \text { H } & 5.28294300 & 0.94261400 & -0.37655000 \\ \text { H } & 5.18126300 & -0.77697900 & -0.44925800 \\ \text { H } & 0.92181500 & 3.52168800 & 0.46244400 \\ \text { H } & -0.92185000 & 3.52168300 & 0.46239400\end{array}$

Sum of Electronic and Thermal Free Energies $=-830.427342$ 
<smiles></smiles>

Triplet Scan
uB3LYP/6-31+G(d,p) smd=water (Reactant)

$\begin{array}{lrrr}\text { C } & -0.88286300 & -3.37226700 & -0.08284300 \\ \mathrm{C} & -1.98584800 & -2.50642800 & 0.18082700 \\ \mathrm{C} & -0.20872500 & -1.22105300 & -0.29936600 \\ \mathrm{C} & 0.48823500 & -0.00789800 & -0.50666500 \\ \mathrm{C} & -0.18515300 & 1.22377000 & -0.30451900 \\ \mathrm{C} & 0.22522800 & -2.55822900 & -0.38114300 \\ \mathrm{C} & 1.92554900 & -0.02149300 & -0.88808400 \\ \mathrm{C} & -1.94222900 & 2.53913000 & 0.17696700 \\ \mathrm{C} & 0.27521000 & 2.54615400 & -0.38855800 \\ \mathrm{C} & -0.82031000 & 3.38435900 & -0.08817300 \\ \mathrm{~B} & -2.45799700 & 0.02077400 & 0.21816800 \\ \mathrm{~F} & -3.08427300 & 0.02976700 & 1.49600500 \\ \mathrm{~F} & -3.50656900 & 0.03017000 & -0.74866500 \\ \mathrm{~N} & -1.55242200 & 1.24645600 & 0.04799400 \\ \mathrm{~N} & -1.57373700 & -1.21825700 & 0.05167400 \\ \mathrm{H} & -3.00113900 & -2.76710200 & 0.44512000 \\ \mathrm{H} & 1.22393600 & -2.89369900 & -0.62074400 \\ \mathrm{H} & -2.95209800 & 2.82062900 & 0.44013500 \\ \mathrm{H} & 1.27953800 & 2.86424800 & -0.62755300 \\ \mathrm{~N} & -0.84991700 & 4.73323900 & -0.03569900 \\ \mathrm{H} & -1.71063600 & 5.22451600 & 0.16234700 \\ \mathrm{H} & -0.03055900 & 5.27696600 & -0.26849400 \\ \mathrm{~N} & -0.93209900 & -4.72964600 & 0.00239400 \\ \mathrm{H} & -0.16829700 & -5.27053000 & -0.38067600 \\ \mathrm{H} & -1.83512100 & -5.18458700 & 0.03099400 \\ \mathrm{H} & 2.19291700 & -0.91585700 & -1.45287200 \\ \mathrm{H} & 2.20568400 & 0.85925700 & -1.46810900 \\ \mathrm{O} & 2.75371600 & -0.01643600 & 0.34333700 \\ \mathrm{C} & 4.08686600 & -0.02981900 & 0.18364400 \\ \mathrm{O} & 4.62758000 & -0.04388200 & -0.91940200 \\ \mathrm{C} & 4.81597400 & -0.02798200 & 1.49627500 \\ \mathrm{H} & 5.89214600 & -0.01770200 & 1.32311200 \\ \mathrm{H} & 4.52463100 & 0.84916900 & 2.08221300 \\ \mathrm{H} & 4.54181600 & -0.91807600 & 2.07143600\end{array}$

SCF Energy = -1059.34470949 
<smiles></smiles>

Triplet Scan
uB3LYP/6-31+G(d,p) smd=water (Transition)

$\begin{array}{lrrr}\text { C } & -0.88171100 & -3.38556800 & -0.11557000 \\ \mathrm{C} & -1.97316700 & -2.52362100 & 0.23587200 \\ \mathrm{C} & -0.26541100 & -1.23861700 & -0.41506100 \\ \mathrm{C} & 0.40191800 & 0.00333300 & -0.69981400 \\ \mathrm{C} & -0.27758900 & 1.23863900 & -0.41507600 \\ \mathrm{C} & 0.18354500 & -2.55551000 & -0.52165000 \\ \mathrm{C} & 1.70875000 & 0.00985100 & -1.18495000 \\ \mathrm{C} & -1.99788700 & 2.50679400 & 0.23583700 \\ \mathrm{C} & 0.15856600 & 2.55985900 & -0.52117600 \\ \mathrm{C} & -0.91472000 & 3.37939700 & -0.11487500 \\ \mathrm{~B} & -2.48004300 & -0.01081900 & 0.30965500 \\ \mathrm{~F} & -2.96042700 & -0.01280800 & 1.63835800 \\ \mathrm{~F} & -3.59836500 & -0.01664600 & -0.55769600 \\ \mathrm{~N} & -1.60402600 & 1.23214900 & 0.05518900 \\ \mathrm{~N} & -1.59173700 & -1.24515500 & 0.05558500 \\ \mathrm{H} & -2.95768400 & -2.79503100 & 0.59155900 \\ \mathrm{H} & 1.16121600 & -2.88083900 & -0.84524800 \\ \mathrm{H} & -2.98507300 & 2.76841900 & 0.59147700 \\ \mathrm{H} & 1.13314600 & 2.89477500 & -0.84431000 \\ \mathrm{~N} & -0.97054600 & 4.72264200 & -0.04677000 \\ \mathrm{H} & -1.80658700 & 5.19129900 & 0.27561500 \\ \mathrm{H} & -0.17205000 & 5.28677800 & -0.30452500 \\ \mathrm{~N} & -0.92475600 & -4.72935900 & -0.04845000 \\ \mathrm{H} & -0.12119600 & -5.28584300 & -0.30712700 \\ \mathrm{H} & -1.75648000 & -5.20615900 & 0.27314300 \\ \mathrm{H} & 2.15366700 & -0.90473700 & -1.55180300 \\ \mathrm{H} & 2.14440300 & 0.92896800 & -1.55164700 \\ \mathrm{O} & 2.95123400 & 0.01639300 & 0.48815700 \\ \mathrm{C} & 4.22337200 & 0.01656700 & 0.27610900 \\ \mathrm{O} & 4.75935100 & 0.01562600 & -0.86150800 \\ \mathrm{C} & 5.08781800 & 0.01570000 & 1.52920200 \\ \mathrm{H} & 6.14888500 & 0.03490800 & 1.27296700 \\ \mathrm{H} & 4.84559100 & 0.88637500 & 2.14715200 \\ \mathrm{H} & 4.87338400 & -0.87877900 & 2.12333800 \\ \mathrm{H} & & & \end{array}$

SCF Energy = -1059.32863872 


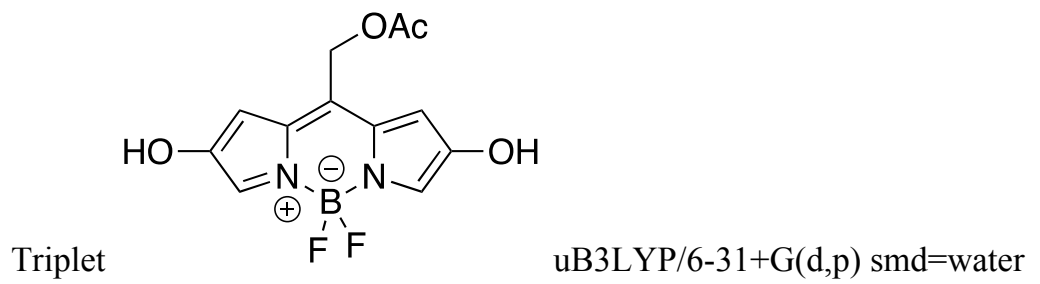

$\begin{array}{lrrr}\text { C } & 0.14800400 & 1.21297500 & -0.29849500 \\ \text { C } & -0.47807700 & -0.03942200 & -0.50222200 \\ \text { C } & 0.27485900 & -1.21819100 & -0.28938600 \\ \text { B } & 2.47888800 & 0.11868600 & 0.19969200 \\ \text { F } & 3.12191300 & 0.15714700 & 1.46174600 \\ \text { F } & 3.49475100 & 0.16947200 & -0.79189700 \\ \text { N } & 1.63847600 & -1.15945800 & 0.05308000 \\ \text { N } & 1.50911400 & 1.30072700 & 0.04645600 \\ \text { C } & -0.38567000 & 2.52320600 & -0.37323900 \\ \text { C } & 1.83247000 & 2.60993900 & 0.18254200 \\ \text { C } & 0.66225500 & 3.38675600 & -0.07272500 \\ \text { C } & 2.09940400 & -2.42671800 & 0.19151000 \\ \text { C } & -0.11701600 & -2.57826000 & -0.35733600 \\ \text { C } & 1.01833300 & -3.32413800 & -0.05957400 \\ \text { C } & -1.91383500 & -0.11251900 & -0.88948000 \\ \text { H } & -2.21737400 & 0.74725800 & -1.48877500 \\ \text { H } & -2.14188400 & -1.02499500 & -1.44233400 \\ \text { O } & -2.74037200 & -0.11474000 & 0.33604900 \\ \text { C } & -4.07403700 & -0.16672600 & 0.17117500 \\ \text { O } & -4.60699600 & -0.21107200 & -0.93380800 \\ \text { C } & -4.80688000 & -0.16871400 & 1.48100000 \\ \text { H } & -4.51729300 & 0.70485700 & 2.07272000 \\ \text { H } & -5.88236700 & -0.15899900 & 1.30387100 \\ \text { H } & -4.53470200 & -1.06246000 & 2.05176300 \\ \text { O } & 1.18485900 & -4.66120500 & 0.013512000 \\ \text { H } & 0.34828100 & -5.11717600 & -0.17879000 \\ \text { O } & 0.68345600 & 4.73373000 & 0.00178600 \\ \text { H } & -0.19768600 & 5.09736400 & -0.188742000 \\ \text { H } & -1.40665200 & 2.79079700 & -0.602753000 \\ \text { H } & 2.82600000 & 2.94641900 & 0.442097000 \\ \text { H } & 3.12344700 & -2.65482600 & 0.450445000 \\ \text { H } & -1.10375800 & -2.95294300 & -0.58627200\end{array}$

Sum of Electronic and Thermal Free Energies $=-1098.878798$ 
<smiles></smiles>

$\begin{array}{lrrr}\text { C } & -1.24084400 & 0.86973100 & -0.00007200 \\ \text { C } & 0.00000000 & 1.60665200 & -0.00040200 \\ \text { C } & 1.24084400 & 0.86973100 & -0.00007200 \\ \text { B } & 0.00000000 & -1.47287300 & -0.00068300 \\ \text { F } & 0.00000200 & -2.27807700 & -1.14624100 \\ \text { F } & -0.00000100 & -2.28021300 & 1.14337500 \\ \text { N } & 1.24313300 & -0.53842000 & 0.00022900 \\ \text { N } & -1.24313300 & -0.53842000 & 0.00022600 \\ \text { C } & -2.56505200 & 1.33861000 & 0.00036100 \\ \text { C } & -2.51018100 & -0.95208800 & 0.00080700 \\ \text { C } & -3.37075600 & 0.20666500 & 0.00061800 \\ \text { C } & 2.51018100 & -0.95208700 & 0.00081200 \\ \text { C } & 2.56505200 & 1.33861000 & 0.00036000 \\ \text { C } & 3.37075600 & 0.20666600 & 0.00061800 \\ \text { C } & -0.00000100 & 2.98338900 & -0.00119100 \\ \text { H } & -0.92650700 & 3.54503100 & -0.00161600 \\ \text { H } & 0.92650400 & 3.54503200 & -0.00158600 \\ \text { O } & 4.69675100 & 0.07026600 & 0.00095600 \\ \text { H } & 5.14124800 & 0.93669000 & 0.00007200 \\ \text { O } & -4.69675000 & 0.07026500 & 0.00095700 \\ \text { H } & -5.14124800 & 0.93669000 & 0.00007600 \\ \text { H } & -2.88934300 & 2.36837900 & 0.00039000 \\ \text { H } & -2.79301600 & -1.99643400 & 0.00098300 \\ \text { H } & 2.79301600 & -1.99643300 & 0.00099000 \\ \text { H } & 2.88934300 & 2.36837900 & 0.00038800\end{array}$

Sum of Electronic and Thermal Free Energies $=-870.242083$ 
<smiles></smiles>

$\begin{array}{rrrr}\text { C } & -1.25290500 & 0.85769100 & 0.04652900 \\ \mathrm{C} & 0.00000000 & 1.59075800 & 0.20692000 \\ \mathrm{C} & 1.25290400 & 0.85769100 & 0.04652700 \\ \mathrm{~B} & 0.00000000 & -1.46889400 & 0.27290200 \\ \mathrm{~F} & 0.00000000 & -2.54480100 & -0.57904300 \\ \mathrm{~F} & 0.00000200 & -1.80893300 & 1.60762500 \\ \mathrm{~N} & 1.24420100 & -0.54351300 & -0.02382500 \\ \mathrm{~N} & -1.24420200 & -0.54351300 & -0.02382300 \\ \mathrm{C} & -2.56428300 & 1.32943800 & -0.10387500 \\ \mathrm{C} & -2.49115200 & -0.96588000 & -0.20850200 \\ \mathrm{C} & -3.35940500 & 0.19352600 & -0.26959900 \\ \mathrm{C} & 2.49115200 & -0.96588000 & -0.20850100 \\ \mathrm{C} & 2.56428200 & 1.32943900 & -0.10388000 \\ \mathrm{C} & 3.35940500 & 0.19352700 & -0.26959900 \\ \mathrm{C} & 0.00000000 & 2.92069700 & 0.48520200 \\ \mathrm{H} & -0.92157700 & 3.47600600 & 0.61353100 \\ \mathrm{H} & 0.92157700 & 3.47600700 & 0.61352400 \\ \mathrm{O} & 4.66036900 & 0.04191000 & -0.46624800 \\ \mathrm{H} & 5.13829600 & 0.88666600 & -0.48114800 \\ \mathrm{O} & -4.66036800 & 0.04191000 & -0.46625000 \\ \mathrm{H} & -5.13829500 & 0.88666600 & -0.48115000 \\ \mathrm{H} & -2.88694100 & 2.35987300 & -0.12649300 \\ \mathrm{H} & -2.75681000 & -2.01222200 & -0.28365800 \\ \mathrm{H} & 2.75681000 & -2.01222200 & -0.28365400 \\ \mathrm{H} & 2.88694000 & 2.35987400 & -0.12650200\end{array}$

Uncorrected Sum of Electronic and Thermal Free Energies $=-870.136901$

Corrected Sum of Electronic and Thermal Free Energies $=-870.130539$ 


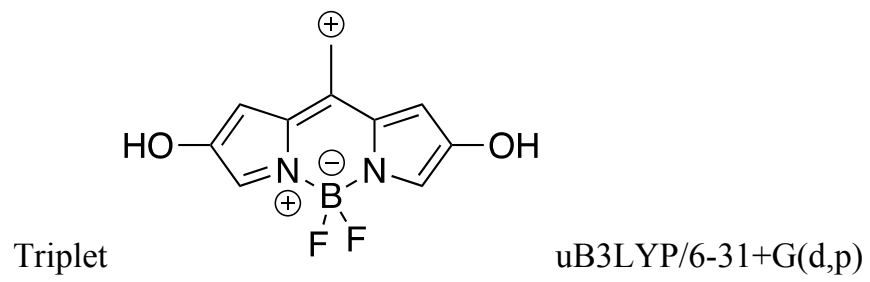

$\begin{array}{lrrr}\text { C } & -1.24489900 & 0.86152400 & 0.03916800 \\ \text { C } & 0.00000000 & 1.59279300 & 0.14514800 \\ \text { C } & 1.24489900 & 0.86152400 & 0.03916800 \\ \text { B } & 0.00000000 & -1.48684400 & 0.19306200 \\ \text { F } & 0.00000100 & -2.49203000 & -0.74162400 \\ \text { F } & -0.00000100 & -1.93674000 & 1.49416100 \\ \text { N } & 1.24478600 & -0.54205600 & -0.03026900 \\ \text { N } & -1.24478600 & -0.54205600 & -0.03027100 \\ \text { C } & -2.56763100 & 1.33340300 & -0.05641300 \\ \text { C } & -2.49764000 & -0.95724200 & -0.16331200 \\ \text { C } & -3.36792900 & 0.20220900 & -0.18886900 \\ \text { C } & 2.49764100 & -0.95724200 & -0.16331000 \\ \text { C } & 2.56763100 & 1.33340300 & -0.05641500 \\ \text { C } & 3.36792900 & 0.20220900 & -0.18886900 \\ \text { C } & 0.00000000 & 2.95835100 & 0.31958500 \\ \text { H } & -0.92167700 & 3.52122100 & 0.39974700 \\ \text { H } & 0.92167700 & 3.52122100 & 0.39974800 \\ \text { O } & 4.67714900 & 0.04696500 & -0.32814600 \\ \text { H } & 5.15695600 & 0.89049800 & -0.32458100 \\ \text { O } & -4.67714900 & 0.04696500 & -0.32814700 \\ \text { H } & -5.15695600 & 0.89049800 & -0.32458000 \\ \text { H } & -2.89103700 & 2.36373000 & -0.05665300 \\ \text { H } & -2.76944500 & -2.00300100 & -0.22816400 \\ \text { H } & 2.76944600 & -2.00300200 & -0.22816000 \\ \text { H } & 2.89103600 & 2.36373000 & -0.05665700\end{array}$

Sum of Electronic and Thermal Free Energies $=-870.143268$ 
<smiles></smiles>

Triplet Scan

uB3LYP/6-31+G(d,p) smd=water (Reactant)

$\mathrm{C}$
$\mathrm{C}$
$\mathrm{C}$
$\mathrm{B}$
$\mathrm{F}$
$\mathrm{F}$
$\mathrm{N}$
$\mathrm{N}$
$\mathrm{C}$
$\mathrm{C}$
$\mathrm{C}$
$\mathrm{C}$
$\mathrm{C}$
$\mathrm{C}$
$\mathrm{C}$
$\mathrm{H}$
$\mathrm{H}$
$\mathrm{O}$
$\mathrm{C}$
$\mathrm{O}$
$\mathrm{C}$
$\mathrm{H}$
$\mathrm{H}$
$\mathrm{H}$
$\mathrm{O}$
$\mathrm{H}$
$\mathrm{O}$
$\mathrm{H}$
$\mathrm{H}$
$\mathrm{H}$
$\mathrm{H}$
$\mathrm{H}$
$\mathrm{H}$

SCF Energy $=-1099.05553104$
0.14800400

$-0.47807700$

0.27485900

2.47888800

3.12191300

3.49475100

1.63847600

1.50911400

$-0.38567000$

1.83247000

0.66225500

2. 09940400

$-0.11701600$

1.01833300

$-1.91383500$

$-2.21737400$

$-2.14188400$

$-2.74037200$

$-4.07403700$

$-4.60699600$

$-4.80688000$

$-4.51729300$

$-5.88236700$

$-4.53470200$

1. 18485900

0.34828100

0.68345600

$-0.19768600$

$-1.40665200$

2. 82600000

3. 12344700

$-1.10375800$
1. 21297500

$-0.03942200$

$-1.21819100$

0.11868600

0.15714700

0.16947200

$-1.15945800$

1. 30072700

2. 52320600

2. 60993900

3. 38675600

$-2.42671800$

$-2.57826000$

$-3.32413800$

$-0.11251900$

0.74725800

$-1.02499500$

$-0.11474000$

$-0.16672600$

$-0.21107200$

$-0.16871400$

0.70485700

$-0.15899900$

$-1.06246000$

$-4.66120500$

$-5.11717600$

4.73373000

5.09736400

2.79079700

2. 94641900

$-2.65482600$

$-2.95294300$
$-0.29849500$

$-0.50222200$

$-0.28938600$

0.19969200

1.46174600

$-0.79189700$

0.05308000

0.04645600

$-0.37323900$

0.18254200

$-0.07272500$

0.19151000

$-0.35733600$

$-0.05957400$

$-0.88948000$

$-1.48877500$

$-1.44233400$

0.33604900

0.17117500

$-0.93380800$

1. 48100000

2. 07272000

1. 30387100

2. 05176300

0.01351200

$-0.17879000$

0.00178600

$-0.18874200$

$-0.60275300$

0.44209700

0.45044500

$-0.58627200$ 


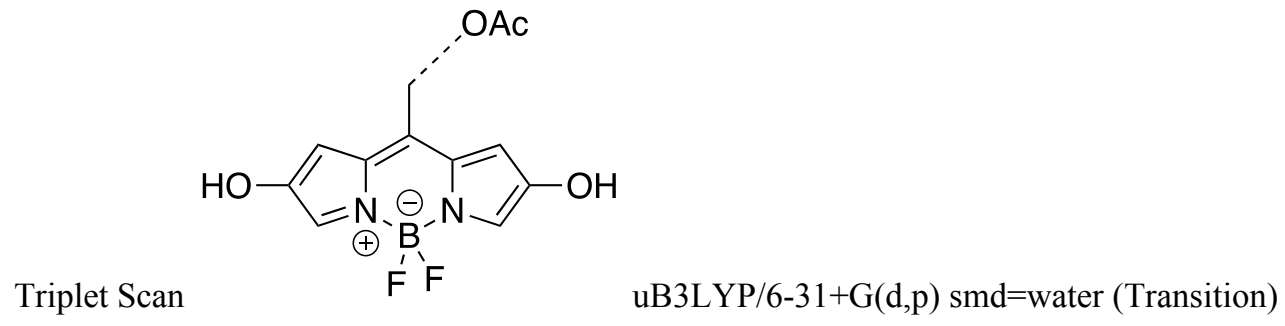

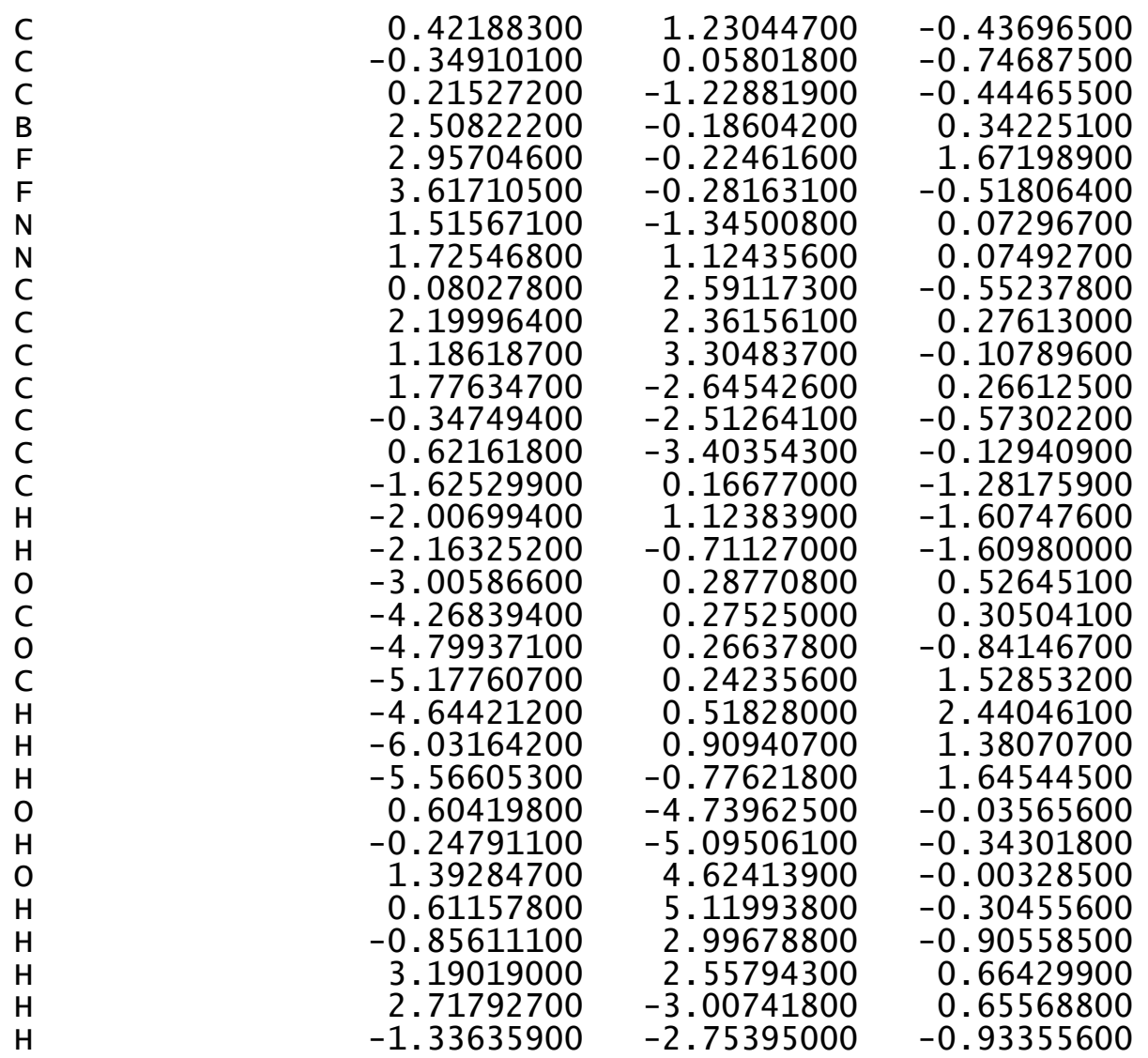

SCF Energy = -1099.03380297 


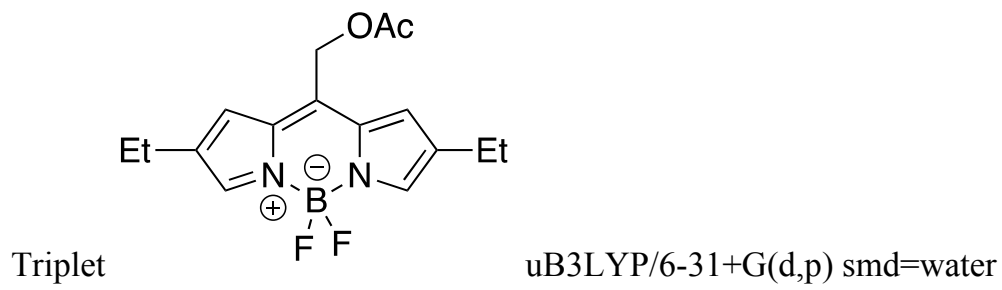

$\begin{array}{lrrr}\text { C } & -3.39851500 & -0.66441900 & 0.02452300 \\ \mathrm{C} & -2.53532800 & -1.75409700 & 0.35401100 \\ \mathrm{C} & -1.21352100 & -0.04188400 & -0.18144800 \\ \mathrm{C} & 0.00000200 & 0.65004200 & -0.41078800 \\ \mathrm{C} & 1.21351500 & -0.04190000 & -0.18145000 \\ \mathrm{C} & -2.57424800 & 0.39906700 & -0.30573100 \\ \mathrm{C} & 0.00001100 & 2.07401100 & -0.84371400 \\ \mathrm{H} & -0.88701800 & 2.32525700 & -1.42696300 \\ \mathrm{O} & 0.00002300 & 2.93411500 & 0.35911700 \\ \mathrm{H} & 0.88703900 & 2.32524300 & -1.42697100 \\ \mathrm{C} & 2.53530000 & -1.75413200 & 0.35400300 \\ \mathrm{C} & 2.57424800 & 0.39903400 & -0.30573000 \\ \mathrm{C} & 3.39850100 & -0.66446300 & 0.02452200 \\ \mathrm{~B} & -0.00001700 & -2.24745200 & 0.50456900 \\ \mathrm{~F} & -0.00002500 & -3.39374400 & -0.33272600 \\ \mathrm{~F} & -0.00001900 & -2.70845300 & 1.84734000 \\ \mathrm{~N} & 1.23146000 & -1.37043400 & 0.22961900 \\ \mathrm{~N} & -1.23148300 & -1.37041800 & 0.22962000 \\ \mathrm{C} & 0.00003700 & 4.26402000 & 0.15879100 \\ \mathrm{O} & 0.00003800 & 4.76893500 & -0.96015000 \\ \mathrm{C} & 0.00005300 & 5.03042200 & 1.44931100 \\ \mathrm{H} & 0.00005200 & 6.10106600 & 1.24484600 \\ \mathrm{H} & -0.88364300 & 4.76427100 & 2.03765300 \\ \mathrm{H} & 0.88376300 & 4.76426900 & 2.03763000 \\ \mathrm{C} & -4.89708700 & -0.71256800 & 0.03595800 \\ \mathrm{H} & -5.23723600 & -1.04730400 & 1.02450300 \\ \mathrm{H} & -5.28443500 & 0.30087900 & -0.10941000 \\ \mathrm{C} & 4.89707300 & -0.71263200 & 0.03595900 \\ \mathrm{H} & 5.23721600 & -1.04737800 & 1.02450200 \\ \mathrm{H} & 5.28443300 & 0.30081200 & -0.10940200 \\ \mathrm{C} & -5.48055300 & -1.65247700 & -1.03462600 \\ \mathrm{H} & -5.19298200 & -1.32833400 & -2.04056200 \\ \mathrm{H} & -5.12815100 & -2.68005600 & -0.89515700 \\ \mathrm{H} & -6.57419800 & -1.65907400 & -0.97726700 \\ \mathrm{C} & 5.48052900 & -1.65254000 & -1.03463000 \\ \mathrm{H} & 6.57417400 & -1.65915100 & -0.97726900 \\ \mathrm{H} & 5.12811300 & -2.68011600 & -0.89516800 \\ \mathrm{H} & 5.19296300 & -1.32838700 & -2.04056500 \\ \mathrm{H} & -2.79603600 & -2.75509500 & 0.67059400 \\ \mathrm{H} & -2.88177700 & 1.39198100 & -0.60305800 \\ \mathrm{H} & 2.88178900 & 1.39194500 & -0.60305200 \\ \mathrm{H} & 2.79599500 & -2.75513400 & 0.67058200 \\ & & & \end{array}$

Sum of Electronic and Thermal Free Energies $=-1105.595260$ 


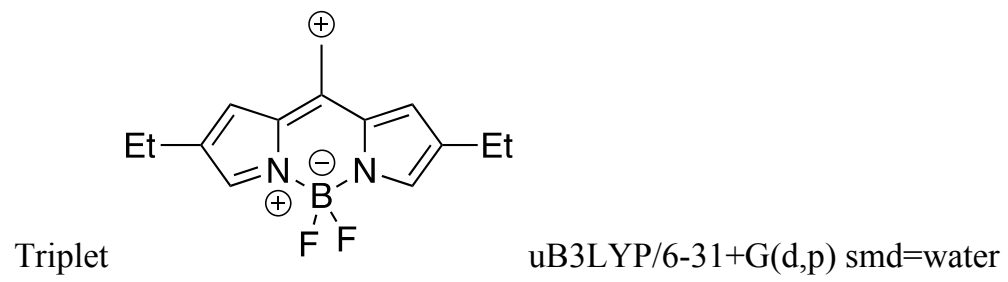

\begin{tabular}{lrrr} 
C & 3.40408800 & 0.28941300 & -0.14230300 \\
$\mathrm{C}$ & 2.52211000 & -0.85630100 & -0.20486100 \\
$\mathrm{C}$ & 1.23291300 & 0.93217900 & -0.13694000 \\
$\mathrm{C}$ & 0.00000000 & 1.67331300 & -0.11542300 \\
$\mathrm{C}$ & -1.23291300 & 0.93217900 & -0.13694000 \\
$\mathrm{C}$ & 2.58220900 & 1.39433600 & -0.10006300 \\
$\mathrm{C}$ & 0.00000000 & 3.05386000 & -0.07190700 \\
$\mathrm{H}$ & 0.92732100 & 3.61369300 & -0.05552200 \\
$\mathrm{H}$ & -0.92732100 & 3.61369300 & -0.05552300 \\
$\mathrm{C}$ & -2.52211000 & -0.85630100 & -0.20486100 \\
$\mathrm{C}$ & -2.58220900 & 1.39433600 & -0.10006300 \\
$\mathrm{C}$ & -3.40408800 & 0.28941300 & -0.14230300 \\
$\mathrm{~B}$ & 0.00000000 & -1.39499600 & -0.26928100 \\
$\mathrm{~F}$ & 0.00000000 & -2.28114000 & 0.81435700 \\
$\mathrm{~F}$ & 0.00000000 & -2.11711400 & -1.46948800 \\
$\mathrm{~N}$ & -1.24185600 & -0.45989900 & -0.20147800 \\
$\mathrm{~N}$ & 1.24185600 & -0.45989900 & -0.20147800 \\
$\mathrm{C}$ & 4.89575700 & 0.21574200 & -0.11917300 \\
$\mathrm{H}$ & 5.23060400 & -0.36116800 & -0.99103000 \\
$\mathrm{H}$ & 5.30128700 & 1.22633400 & -0.22149800 \\
$\mathrm{C}$ & -4.89575700 & 0.21574200 & -0.11917300 \\
$\mathrm{H}$ & -5.23060400 & -0.36116800 & -0.99103000 \\
$\mathrm{H}$ & -5.30128700 & 1.22633400 & -0.22149800 \\
$\mathrm{C}$ & 5.44212300 & -0.44896300 & 1.15895400 \\
$\mathrm{H}$ & 5.16165300 & 0.12378800 & 2.04876200 \\
$\mathrm{H}$ & 5.05892500 & -1.46853000 & 1.27291000 \\
$\mathrm{H}$ & 6.53444100 & -0.50009700 & 1.11249700 \\
$\mathrm{C}$ & -5.44212300 & -0.44896300 & 1.15895400 \\
$\mathrm{H}$ & -6.53444100 & -0.50009700 & 1.11249700 \\
$\mathrm{H}$ & -5.05892600 & -1.46853000 & 1.27291000 \\
$\mathrm{H}$ & -5.16165300 & 0.12378800 & 2.04876200 \\
$\mathrm{H}$ & 2.78883200 & -1.90453300 & -0.25708600 \\
$\mathrm{H}$ & 2.88821300 & 2.42947400 & -0.04909900 \\
$\mathrm{H}$ & -2.88821300 & 2.42947400 & -0.04909900 \\
$\mathrm{H}$ & -2.78883200 & -1.90453300 & -0.25708600 \\
& & & \\
\hline
\end{tabular}

Sum of Electronic and Thermal Free Energies $=-876.959214$ 
<smiles></smiles>

$\begin{array}{lrrr}\text { C } & 3.41881400 & 0.28822200 & -0.23948200 \\ \mathrm{C} & 2.52525900 & -0.85591000 & -0.26976900 \\ \mathrm{C} & 1.24978600 & 0.92661300 & -0.08110100 \\ \mathrm{C} & 0.00000000 & 1.66403200 & 0.00611800 \\ \mathrm{C} & -1.24978600 & 0.92661300 & -0.08110200 \\ \mathrm{C} & 2.59954900 & 1.39163000 & -0.11731600 \\ \mathrm{C} & 0.00000000 & 3.01914900 & 0.15796700 \\ \mathrm{H} & 0.92204200 & 3.58448000 & 0.22544000 \\ \mathrm{H} & -0.92204300 & 3.58447600 & 0.22546300 \\ \mathrm{C} & -2.52525900 & -0.85591000 & -0.26977000 \\ \mathrm{C} & -2.59954800 & 1.39163000 & -0.11731800 \\ \mathrm{C} & -3.41881300 & 0.28822300 & -0.23948200 \\ \mathrm{~B} & 0.00000000 & -1.41533200 & -0.09607200 \\ \mathrm{~F} & 0.00000000 & -2.06449000 & 1.12009500 \\ \mathrm{~F} & 0.00000000 & -2.27553500 & -1.17007100 \\ \mathrm{~N} & -1.24826900 & -0.45359000 & -0.17814100 \\ \mathrm{~N} & 1.24826900 & -0.45359000 & -0.17814100 \\ \mathrm{C} & 4.90973800 & 0.21571100 & -0.31649200 \\ \mathrm{H} & 5.19068100 & -0.35242400 & -1.21336300 \\ \mathrm{H} & 5.31034600 & 1.22562400 & -0.44406500 \\ \mathrm{C} & -4.90973800 & 0.21571200 & -0.31649100 \\ \mathrm{H} & -5.19068100 & -0.35242200 & -1.21336400 \\ \mathrm{H} & -5.31034500 & 1.22562500 & -0.44406200 \\ \mathrm{C} & 5.54619300 & -0.45297100 & 0.92252500 \\ \mathrm{H} & 5.31944900 & 0.10876100 & 1.83326000 \\ \mathrm{H} & 5.19231200 & -1.48000700 & 1.05722000 \\ \mathrm{H} & 6.63226500 & -0.48826800 & 0.80314400 \\ \mathrm{C} & -5.54619300 & -0.45297200 & 0.92252500 \\ \mathrm{H} & -6.63226500 & -0.48826800 & 0.80314500 \\ \mathrm{H} & -5.19231200 & -1.48000900 & 1.05721800 \\ \mathrm{H} & -5.31944800 & 0.10875800 & 1.83326100 \\ \mathrm{H} & 2.77199500 & -1.90704100 & -0.35715600 \\ \mathrm{H} & 2.91918600 & 2.42313100 & -0.07486700 \\ \mathrm{H} & -2.91918500 & 2.42313100 & -0.07486800 \\ \mathrm{H} & -2.77199500 & -1.90704100 & -0.35715600 \\ & & & \end{array}$

Uncorrected Sum of Electronic and Thermal Free Energies $=-876.873056$

Corrected Sum of Electronic and Thermal Free Energies $=-876.869261$ 


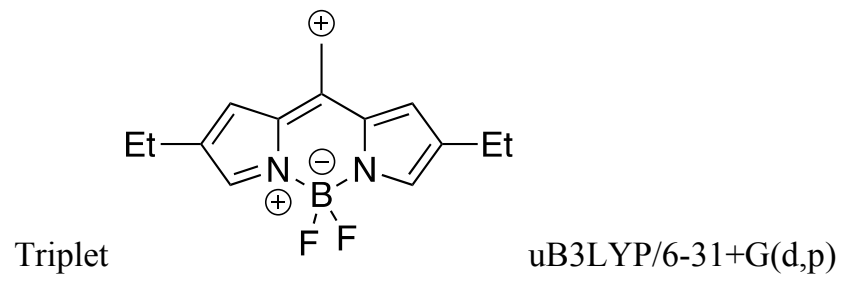

\begin{tabular}{lrrr} 
C & \multicolumn{1}{c}{ 3.40947900 } & 0.29255100 & -0.23836200 \\
$\mathrm{C}$ & 2.51598000 & -0.85574300 & -0.26910000 \\
$\mathrm{C}$ & 1.23824600 & 0.92800500 & -0.07894400 \\
$\mathrm{C}$ & 0.00000000 & 1.66286600 & 0.00668500 \\
$\mathrm{C}$ & -1.23824600 & 0.92800500 & -0.07894300 \\
$\mathrm{C}$ & 2.58811100 & 1.39310400 & -0.11507600 \\
$\mathrm{H}$ & 0.00000000 & 3.03786100 & 0.15163400 \\
$\mathrm{H}$ & 0.92270200 & 3.60105000 & 0.21490100 \\
$\mathrm{C}$ & -0.92270100 & 3.60105100 & 0.21489400 \\
$\mathrm{C}$ & -2.51598000 & -0.85574300 & -0.26910000 \\
$\mathrm{C}$ & -2.58811100 & 1.39310400 & -0.11507500 \\
$\mathrm{~B}$ & -3.40947900 & 0.29255200 & -0.23836100 \\
$\mathrm{~F}$ & 0.00000000 & -1.42635000 & -0.09719000 \\
$\mathrm{~F}$ & 0.00000000 & -2.07637700 & 1.11791400 \\
$\mathrm{~N}$ & 0.00000000 & -2.28408300 & -1.17269300 \\
$\mathrm{~N}$ & -1.24519800 & -0.46172300 & -0.17808800 \\
$\mathrm{C}$ & 1.24519800 & -0.46172400 & -0.17808900 \\
$\mathrm{H}$ & 4.89982300 & 0.22088000 & -0.31529900 \\
$\mathrm{H}$ & 5.18072000 & -0.34566600 & -1.21328600 \\
$\mathrm{C}$ & 5.30030600 & 1.23107600 & -0.44047400 \\
$\mathrm{H}$ & -4.89982300 & 0.22088100 & -0.31529900 \\
$\mathrm{H}$ & -5.18072000 & -0.34566500 & -1.21328700 \\
$\mathrm{C}$ & -5.30030600 & 1.23107600 & -0.44047300 \\
$\mathrm{H}$ & 5.53572500 & -0.45092900 & 0.92264500 \\
$\mathrm{H}$ & 5.30931600 & 0.10912400 & 1.83444300 \\
$\mathrm{H}$ & 5.18172400 & -1.47821400 & 1.05516100 \\
$\mathrm{C}$ & 6.62170900 & -0.48622900 & 0.80292900 \\
$\mathrm{H}$ & -5.53572500 & -0.45092900 & 0.92264400 \\
$\mathrm{H}$ & -6.62171000 & -0.48622900 & 0.80292800 \\
$\mathrm{H}$ & -5.18172400 & -1.47821400 & 1.05515900 \\
$\mathrm{H}$ & -5.30931700 & 0.10912300 & 1.83444300 \\
$\mathrm{H}$ & 2.76859600 & -1.90575500 & -0.35632500 \\
$\mathrm{H}$ & 2.90521900 & 2.42523100 & -0.07139900 \\
$\mathrm{H}$ & -2.90521900 & 2.42523100 & -0.07139700 \\
& -2.76859600 & -1.90575500 & -0.35632600
\end{tabular}

Sum of Electronic and Thermal Free Energies $=-876.879649$ 


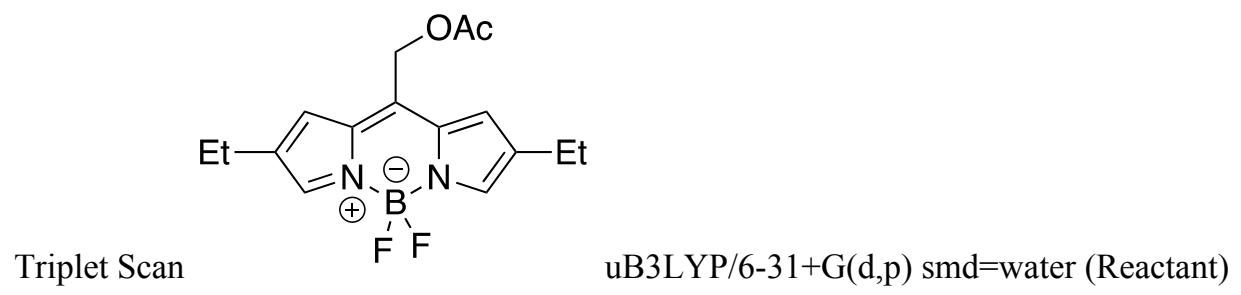

$\begin{array}{lrrr}\text { C } & -3.39851500 & -0.66441900 & 0.02452300 \\ \mathrm{C} & -2.53532800 & -1.75409700 & 0.35401100 \\ \mathrm{C} & -1.21352100 & -0.04188400 & -0.18144800 \\ \mathrm{C} & 0.00000200 & 0.65004200 & -0.41078800 \\ \mathrm{C} & 1.21351500 & -0.04190000 & -0.18145000 \\ \mathrm{C} & -2.57424800 & 0.39906700 & -0.30573100 \\ \mathrm{C} & 0.00001100 & 2.07401100 & -0.84371400 \\ \mathrm{H} & -0.88701800 & 2.32525700 & -1.42696300 \\ \mathrm{O} & 0.00002300 & 2.93411500 & 0.35911700 \\ \mathrm{H} & 0.88703900 & 2.32524300 & -1.42697100 \\ \mathrm{C} & 2.53530000 & -1.75413200 & 0.35400300 \\ \mathrm{C} & 2.57424800 & 0.39903400 & -0.30573000 \\ \mathrm{C} & 3.39850100 & -0.66446300 & 0.02452200 \\ \mathrm{~B} & -0.00001700 & -2.24745200 & 0.50456900 \\ \mathrm{~F} & -0.00002500 & -3.39374400 & -0.33272600 \\ \mathrm{~F} & -0.00001900 & -2.70845300 & 1.84734000 \\ \mathrm{~N} & 1.23146000 & -1.37043400 & 0.22961900 \\ \mathrm{~N} & -1.23148300 & -1.37041800 & 0.22962000 \\ \mathrm{C} & 0.00003700 & 4.26402000 & 0.15879100 \\ \mathrm{O} & 0.00003800 & 4.76893500 & -0.96015000 \\ \mathrm{C} & 0.00005300 & 5.03042200 & 1.44931100 \\ \mathrm{H} & 0.00005200 & 6.10106600 & 1.24484600 \\ \mathrm{H} & -0.88364300 & 4.76427100 & 2.03765300 \\ \mathrm{H} & 0.88376300 & 4.76426900 & 2.03763000 \\ \mathrm{C} & -4.89708700 & -0.71256800 & 0.03595800 \\ \mathrm{H} & -5.23723600 & -1.04730400 & 1.02450300 \\ \mathrm{H} & -5.28443500 & 0.30087900 & -0.10941000 \\ \mathrm{C} & 4.89707300 & -0.71263200 & 0.03595900 \\ \mathrm{H} & 5.23721600 & -1.04737800 & 1.02450200 \\ \mathrm{H} & 5.28443300 & 0.30081200 & -0.10940200 \\ \mathrm{C} & -5.48055300 & -1.65247700 & -1.03462600 \\ \mathrm{H} & -5.19298200 & -1.32833400 & -2.04056200 \\ \mathrm{H} & -5.12815100 & -2.68005600 & -0.89515700 \\ \mathrm{H} & -6.57419800 & -1.65907400 & -0.97726700 \\ \mathrm{C} & 5.48052900 & -1.65254000 & -1.03463000 \\ \mathrm{H} & 6.57417400 & -1.65915100 & -0.97726900 \\ \mathrm{H} & 5.12811300 & -2.68011600 & -0.89516800 \\ \mathrm{H} & 5.19296300 & -1.32838700 & -2.04056500 \\ \mathrm{H} & -2.79603600 & -2.75509500 & 0.67059400 \\ \mathrm{H} & -2.88177700 & 1.39198100 & -0.60305800 \\ \mathrm{H} & 2.88178900 & 1.39194500 & -0.60305200 \\ \mathrm{H} & 2.79599500 & -2.75513400 & 0.67058200\end{array}$

SCF Energy $=-1105.86871525$ 
Triplet Scan

$\begin{array}{lrrr}\text { C } & -3.40135300 & -0.70595100 & -0.01188600 \\ \mathrm{C} & -2.52414800 & -1.75736500 & 0.43360400 \\ \mathrm{C} & -1.22896700 & -0.13712200 & -0.33410900 \\ \mathrm{C} & 0.00000200 & 0.52692300 & -0.66730500 \\ \mathrm{C} & 1.22897800 & -0.13711100 & -0.33412300 \\ \mathrm{C} & -2.57980900 & 0.29665800 & -0.48770500 \\ \mathrm{C} & 0.00000000 & 1.78776900 & -1.25105300 \\ \mathrm{H} & -0.92103100 & 2.23656400 & -1.59449900 \\ \mathrm{O} & 0.00005700 & 3.22783500 & 0.51493800 \\ \mathrm{H} & 0.92103700 & 2.23655700 & -1.59449600 \\ \mathrm{C} & 2.52419100 & -1.75734000 & 0.43357100 \\ \mathrm{C} & 2.57981000 & 0.29669500 & -0.48771500 \\ \mathrm{C} & 3.40137400 & -0.70590200 & -0.01190500 \\ \mathrm{~B} & 0.00002500 & -2.26429400 & 0.59501600 \\ \mathrm{~F} & 0.00002500 & -3.45790200 & -0.14829100 \\ \mathrm{~F} & 0.00004100 & -2.57838600 & 1.96464800 \\ \mathrm{~N} & 1.23863600 & -1.40422000 & 0.23878600 \\ \mathrm{~N} & -1.23859900 & -1.40422700 & 0.23880900 \\ \mathrm{C} & -0.00019000 & 4.48570600 & 0.26141800 \\ \mathrm{O} & -0.00047400 & 4.98692500 & -0.89722500 \\ \mathrm{C} & 0.00018300 & 5.40406400 & 1.47884000 \\ \mathrm{H} & -0.00252100 & 6.45478500 & 1.18186400 \\ \mathrm{H} & -0.88065700 & 5.19826600 & 2.09590200 \\ \mathrm{H} & 0.88452800 & 5.20196000 & 2.09214500 \\ \mathrm{C} & -4.89540000 & -0.75367900 & 0.04057200 \\ \mathrm{H} & -5.20590000 & -0.99881200 & 1.06427300 \\ \mathrm{H} & -5.28942500 & 0.24075000 & -0.18927700 \\ \mathrm{C} & 4.89542100 & -0.75360300 & 0.04055000 \\ \mathrm{H} & 5.20592800 & -0.99880200 & 1.06423200 \\ \mathrm{H} & 5.28942400 & 0.24085200 & -0.18923000 \\ \mathrm{C} & -5.49467900 & -1.79314400 & -0.92545100 \\ \mathrm{H} & -5.23781900 & -1.55696600 & -1.96330800 \\ \mathrm{H} & -5.12681200 & -2.80048900 & -0.70346900 \\ \mathrm{H} & -6.58565800 & -1.80245000 & -0.83511800 \\ \mathrm{C} & 5.49472000 & -1.79298500 & -0.92555100 \\ \mathrm{H} & 6.58569900 & -1.80227000 & -0.83522600 \\ \mathrm{H} & 5.12687800 & -2.80035400 & -0.70363700 \\ \mathrm{H} & 5.23784700 & -1.55673900 & -1.96339000 \\ \mathrm{H} & -2.78510600 & -2.71002300 & 0.87642800 \\ \mathrm{H} & -2.88888300 & 1.24727400 & -0.89862500 \\ \mathrm{H} & 2.88886400 & 1.24732300 & -0.89862600 \\ \mathrm{H} & 2.78517000 & -2.70999900 & 0.87637800\end{array}$

SCF Energy $=-1105.84718062$ 


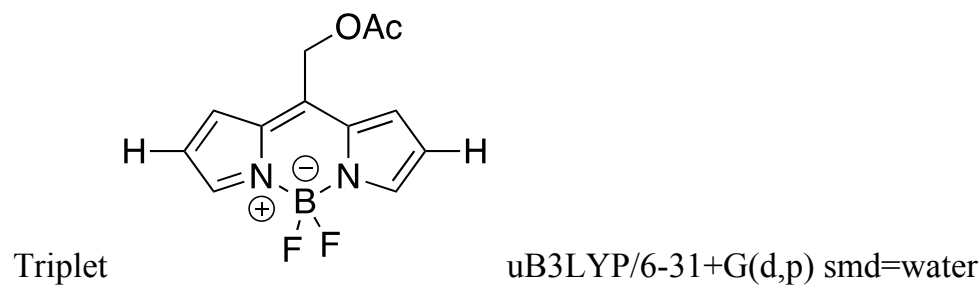

$\begin{array}{lrrr}\text { C } & -0.95518800 & 3.39126100 & -0.13317200 \\ \text { C } & -2.05395300 & 2.54283200 & 0.13723400 \\ \text { C } & -0.32426900 & 1.21131300 & -0.31752400 \\ \text { C } & 0.38049400 & -0.00002000 & -0.51710800 \\ \text { C } & -0.32430700 & -1.21132900 & -0.31751700 \\ \text { C } & 0.12895800 & 2.58153900 & -0.41616000 \\ \text { C } & 1.82136300 & -0.00004400 & -0.89348600 \\ \text { H } & 2.09309700 & 0.88670700 & -1.46795800 \\ \text { O } & 2.63113200 & -0.00005300 & 0.34097400 \\ \text { H } & 2.09306900 & -0.88680700 & -1.46795300 \\ \text { C } & -2.05403300 & -2.54279200 & 0.13724800 \\ \text { C } & 0.12887700 & -2.58157000 & -0.41614300 \\ \text { C } & -0.95529400 & -3.39125700 & -0.13315200 \\ \text { B } & -2.55760000 & 0.00002800 & 0.24722200 \\ \text { F } & -3.64759100 & 0.00004300 & -0.65907500 \\ \text { F } & -3.09459600 & 0.00004100 & 1.55872300 \\ \text { N } & -1.66278900 & -1.23194800 & 0.02510300 \\ \text { N } & -1.66275000 & 1.23197500 & 0.02509500 \\ \text { C } & 3.96879000 & -0.00007200 & 0.19221800 \\ \text { O } & 4.51533900 & -0.00000400 & -0.90648300 \\ \text { C } & 4.68391700 & 0.00002500 & 1.51160000 \\ \text { H } & 5.76167300 & 0.00009400 & 1.34883000 \\ \text { H } & 4.39488000 & 0.88377400 & 2.08894800 \\ \text { H } & 4.39500000 & -0.88372400 & 2.08900600 \\ \text { H } & -0.98295400 & -4.47196000 & -0.11328400 \\ \text { H } & -0.98281300 & 4.47196500 & -0.11331000 \\ \text { H } & -3.07064700 & 2.80049200 & 0.40056700 \\ \text { H } & 1.13604700 & 2.88412300 & -0.66497000 \\ \text { H } & -3.07073500 & -2.80041900 & 0.400582000 \\ \text { H } & 1.13595700 & -2.88418800 & -0.66495100\end{array}$

Sum of Electronic and Thermal Free Energies $=-948.419188$ 


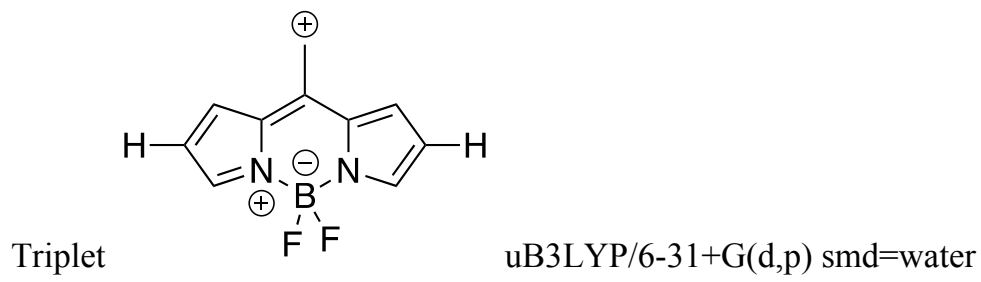

$\begin{array}{lrrr}\text { C } & 3.39640800 & 0.23686400 & -0.00078000 \\ \text { C } & 2.53112500 & -0.90465900 & -0.00094200 \\ \text { C } & 1.23016600 & 0.87661900 & 0.00006700 \\ \text { C } & 0.00000600 & 1.62217100 & 0.00034100 \\ \text { C } & -1.23016200 & 0.87662700 & 0.00005800 \\ \text { C } & 2.59251000 & 1.34634300 & -0.00026900 \\ \text { C } & 0.00001700 & 3.00295800 & 0.00063400 \\ \text { C } & -2.53113200 & -0.90464700 & -0.00093000 \\ \text { C } & -2.59250500 & 1.34635500 & -0.00025900 \\ \text { C } & -3.39640900 & 0.23688100 & -0.00080400 \\ \text { B } & -0.00000500 & -1.44618700 & 0.00046100 \\ \text { F } & -0.00001300 & -2.24724400 & 1.14679900 \\ \text { F } & -0.00000200 & -2.24980700 & -1.14400100 \\ \text { N } & -1.24241900 & -0.50600200 & -0.00049400 \\ \text { N } & 1.24241400 & -0.50600900 & -0.00048300 \\ \text { H } & -4.47623500 & 0.19535300 & -0.00119500 \\ \text { H } & 4.47623300 & 0.19533100 & -0.00115400 \\ \text { H } & 2.79553300 & -1.95431100 & -0.00135500 \\ \text { H } & 2.89361000 & 2.38373300 & -0.00007100 \\ \text { H } & -2.79554600 & -1.95429700 & -0.00134300 \\ \text { H } & -2.89360300 & 2.38374500 & -0.00005300 \\ \text { H } & -0.92735100 & 3.56294000 & 0.00106000 \\ \text { H } & 0.92739800 & 3.56292000 & 0.00076800\end{array}$

Sum of Electronic and Thermal Free Energies $=-719.778030$ 


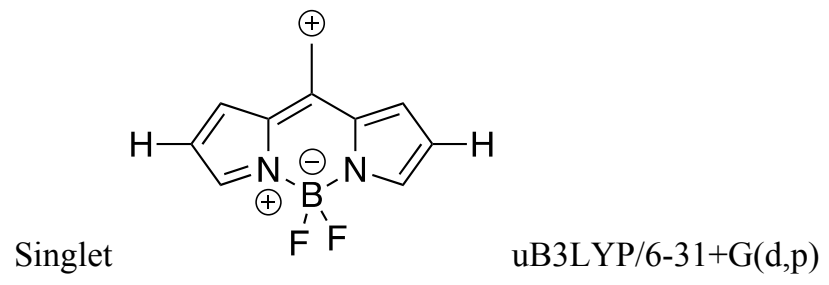

$\begin{array}{lrrr}\text { C } & -0.00000200 & -0.22908700 & 3.41474300 \\ \text { C } & -0.00000500 & 0.90787500 & 2.54201200 \\ \text { C } & 0.00000300 & -0.87085200 & 1.24641400 \\ \text { C } & 0.00000700 & -1.61352400 & 0.00000000 \\ \text { C } & 0.00000300 & -0.87085200 & -1.24641400 \\ \text { C } & 0.00000300 & -1.34183100 & 2.61394400 \\ \text { H } & 0.00001500 & -2.97911000 & 0.00000000 \\ \text { H } & 0.00002000 & -3.54963800 & 0.92161400 \\ \text { C } & 0.00002000 & -3.54963800 & -0.92161400 \\ \text { C } & -0.00000500 & 0.90787500 & -2.54201200 \\ \text { C } & 0.00000300 & -1.34183100 & -2.61394400 \\ \text { B } & -0.00000200 & -0.22908700 & -3.41474300 \\ \text { F } & -0.00000400 & 1.46755700 & 0.00000000 \\ \text { F } & 1.14991400 & 2.21966800 & 0.00000000 \\ \text { N } & -1.14992400 & 2.21966400 & 0.00000000 \\ \text { N } & -0.00000200 & 0.49794400 & -1.25086400 \\ \text { H } & -0.00000200 & 0.49794400 & 1.25086400 \\ \text { H } & -0.00000400 & -0.18850300 & -4.49474400 \\ \text { H } & -0.00000400 & -0.18850300 & 4.49474400 \\ \text { H } & -0.00000900 & 1.96200300 & 2.78981100 \\ \text { H } & 0.00000600 & -2.37408100 & 2.93303400 \\ \text { H } & -0.00000900 & 1.96200300 & -2.78981100 \\ & 0.00000600 & -2.37408100 & -2.93303400\end{array}$

Uncorrected Sum of Electronic and Thermal Free Energies $=-719.684139$

Corrected Sum of Electronic and Thermal Free Energies $=-719.681787$ 


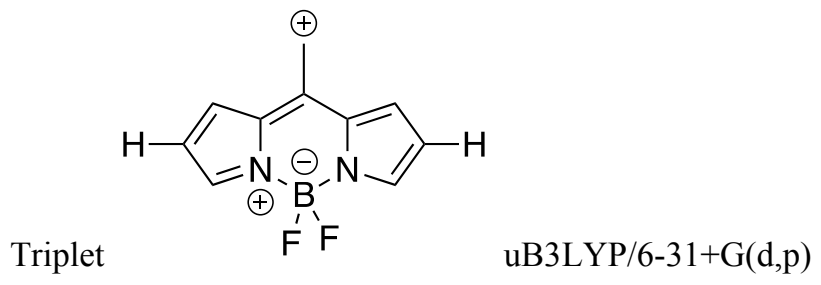

$\begin{array}{lrrr}\text { C } & -0.00000300 & 0.23583200 & 3.40439800 \\ \text { C } & -0.00000100 & -0.90815200 & 2.52933400 \\ \text { C } & -0.00000100 & 0.87390600 & 1.23553800 \\ \text { C } & -0.00000100 & 1.61797000 & 0.00000000 \\ \text { C } & -0.00000100 & 0.87390600 & -1.23553800 \\ \text { C } & -0.00000300 & 1.34458800 & 2.60236500 \\ \text { C } & -0.00000100 & 3.00081600 & 0.00000000 \\ \text { H } & -0.00000100 & 3.56879200 & 0.92207100 \\ \text { H } & -0.00000100 & 3.56879200 & -0.92207100 \\ \text { C } & -0.00000100 & -0.90815200 & -2.52933400 \\ \text { C } & -0.00000300 & 1.34458800 & -2.60236500 \\ \text { C } & -0.00000300 & 0.23583200 & -3.40439800 \\ \text { B } & 0.00000300 & -1.47864300 & 0.00000000 \\ \text { F } & -1.14996900 & -2.23013100 & 0.00000000 \\ \text { F } & 1.14997900 & -2.23012400 & 0.00000000 \\ \text { N } & 0.00000000 & -0.50665000 & -1.24747000 \\ \text { N } & 0.00000000 & -0.50665000 & 1.24747000 \\ \text { H } & -0.00000400 & 0.19549200 & -4.48456200 \\ \text { H } & -0.00000400 & 0.19549200 & 4.48456200 \\ \text { H } & 0.00000000 & -1.96098400 & 2.78401400 \\ \text { H } & -0.00000400 & 2.37759500 & 2.91848900 \\ \text { H } & 0.00000000 & -1.96098400 & -2.78401400 \\ \text { H } & -0.00000400 & 2.37759500 & -2.91848900\end{array}$

Sum of Electronic and Thermal Free Energies $=-719.690160$ 
Triplet Scan

$\begin{array}{lrrr}\text { C } & -0.95518800 & 3.39126100 & -0.13317200 \\ \text { C } & -2.05395300 & 2.54283200 & 0.13723400 \\ \text { C } & -0.32426900 & 1.21131300 & -0.31752400 \\ \text { C } & 0.38049400 & -0.00002000 & -0.51710800 \\ \text { C } & -0.32430700 & -1.21132900 & -0.31751700 \\ \text { C } & 0.12895800 & 2.58153900 & -0.41616000 \\ \text { C } & 1.82136300 & -0.00004400 & -0.89348600 \\ \text { H } & 2.09309700 & 0.88670700 & -1.46795800 \\ \text { O } & 2.63113200 & -0.00005300 & 0.34097400 \\ \text { H } & 2.09306900 & -0.88680700 & -1.46795300 \\ \text { C } & -2.05403300 & -2.54279200 & 0.13724800 \\ \text { C } & 0.12887700 & -2.58157000 & -0.41614300 \\ \text { C } & -0.95529400 & -3.39125700 & -0.13315200 \\ \text { B } & -2.55760000 & 0.00002800 & 0.24722200 \\ \text { F } & -3.64759100 & 0.00004300 & -0.65907500 \\ \text { F } & -3.09459600 & 0.00004100 & 1.55872300 \\ \text { N } & -1.66278900 & -1.23194800 & 0.02510300 \\ \text { N } & -1.66275000 & 1.23197500 & 0.02509500 \\ \text { C } & 3.96879000 & -0.00007200 & 0.19221800 \\ \text { O } & 4.51533900 & -0.00000400 & -0.90648300 \\ \text { C } & 4.68391700 & 0.00002500 & 1.51160000 \\ \text { H } & 5.76167300 & 0.00009400 & 1.34883000 \\ \text { H } & 4.39488000 & 0.88377400 & 2.08894800 \\ \text { H } & 4.39500000 & -0.88372400 & 2.08900600 \\ \text { H } & -0.98295400 & -4.47196000 & -0.11328400 \\ \text { H } & -0.98281300 & 4.47196500 & -0.11331000 \\ \text { H } & -3.07064700 & 2.80049200 & 0.40056700 \\ \text { H } & 1.13604700 & 2.88412300 & -0.66497000 \\ \text { H } & -3.07073500 & -2.80041900 & 0.400582000 \\ \text { H } & 1.13595700 & -2.88418800 & -0.66495100\end{array}$

SCF Energy $=-948.58973686$ 


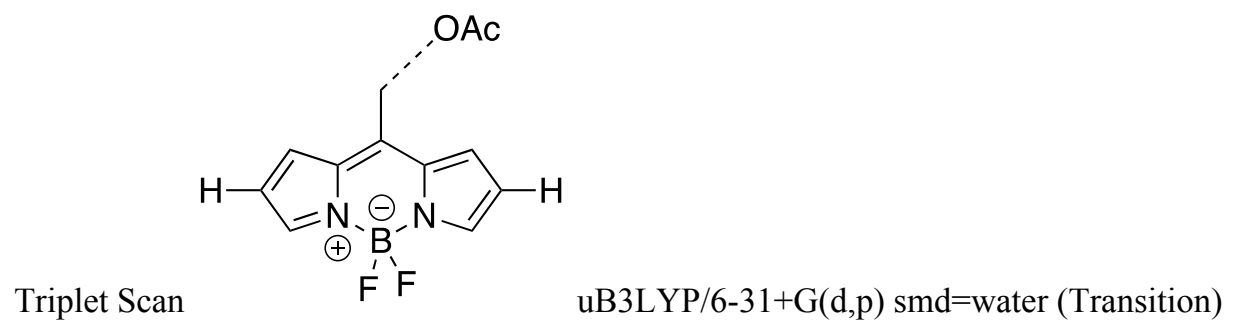

$\begin{array}{lrrr}\text { C } & -1.04403100 & 3.39407400 & -0.18997500 \\ \text { C } & -2.09109700 & 2.53047300 & 0.25305700 \\ \text { C } & -0.47320400 & 1.22775400 & -0.50246800 \\ \text { C } & 0.19781800 & 0.00000200 & -0.83091000 \\ \text { C } & -0.47317600 & -1.22776000 & -0.50244600 \\ \text { C } & -0.03471100 & 2.59031000 & -0.66023600 \\ \text { C } & 1.45519600 & 0.00001100 & -1.41119900 \\ \text { H } & 1.93049100 & 0.92281400 & -1.71280400 \\ \text { O } & 2.96577400 & 0.00022300 & 0.55106400 \\ \text { H } & 1.93052100 & -0.92279100 & -1.71276200 \\ \text { C } & -2.09104500 & -2.53050200 & 0.25309300 \\ \text { C } & -0.03465600 & -2.59030900 & -0.66019600 \\ \text { C } & -1.04395900 & -3.39408800 & -0.18992300 \\ \text { B } & -2.59972900 & -0.00001900 & 0.41666100 \\ \text { F } & -3.78540500 & -0.00003700 & -0.33247600 \\ \text { F } & -2.91105400 & -0.00001300 & 1.78342500 \\ \text { N } & -1.73432300 & -1.23951400 & 0.06121700 \\ \text { N } & -1.73434900 & 1.23949000 & 0.06120000 \\ \text { C } & 4.22667700 & 0.00002100 & 0.33949400 \\ \text { O } & 4.76360900 & -0.00020600 & -0.80744700 \\ \text { C } & 5.11878200 & 0.00006900 & 1.57767000 \\ \text { H } & 6.17700600 & -0.00015000 & 1.30829200 \\ \text { H } & 4.90040700 & 0.88253200 & 2.18839000 \\ \text { H } & 4.90011200 & -0.88212100 & 2.18867700 \\ \text { H } & -1.06954300 & -4.47364700 & -0.14751500 \\ \text { H } & -1.06963800 & 4.47363400 & -0.14758400 \\ \text { H } & -3.04818900 & 2.78941800 & 0.68668700 \\ \text { H } & 0.91687700 & 2.89518000 & -1.07081100 \\ \text { H } & -3.04813300 & -2.78946100 & 0.68672300 \\ \text { H } & 0.91693900 & -2.89516500 & -1.07076600\end{array}$

SCF Energy = -948.56471317 


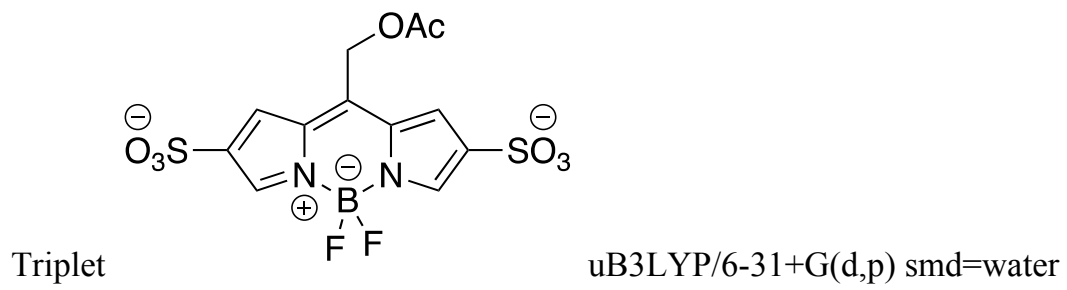

$\begin{array}{lrrr}\text { C } & -3.38441500 & -0.57062200 & -0.09469400 \\ \text { C } & -2.54684400 & -1.68023200 & 0.18456900 \\ \text { C } & -1.21548100 & 0.04760800 & -0.28037400 \\ \text { C } & -0.00055100 & 0.74661000 & -0.48486300 \\ \text { C } & 1.20539500 & 0.03728900 & -0.28250500 \\ \text { C } & -2.57781600 & 0.51240400 & -0.38284600 \\ \text { C } & 0.00567000 & 2.18657100 & -0.86936700 \\ \text { H } & -0.88151100 & 2.45767400 & -1.44351800 \\ \text { O } & 0.01575500 & 2.99699900 & 0.35997000 \\ \text { H } & 0.89075700 & 2.44785000 & -1.45119300 \\ \text { C } & 2.52585000 & -1.70053200 & 0.18101600 \\ \text { C } & 2.57162800 & 0.49033500 & -0.38392900 \\ \text { C } & 3.37113800 & -0.60252000 & -0.09523400 \\ \text { B } & -0.01222800 & -2.19677700 & 0.29857900 \\ \text { F } & -0.02028600 & -3.28318900 & -0.60249700 \\ \text { F } & -0.01411300 & -2.71410200 & 1.61167200 \\ \text { N } & 1.22363400 & -1.30210000 & 0.06668500 \\ \text { N } & -1.24335000 & -1.29085200 & 0.07009800 \\ \text { C } & 0.03494200 & 4.33505900 & 0.20588900 \\ \text { O } & 0.03755800 & 4.87585200 & -0.89505700 \\ \text { C } & 0.05811900 & 5.05375600 & 1.52265100 \\ \text { H } & 0.02781500 & 6.13066300 & 1.35728900 \\ \text { H } & -0.79647300 & 4.74434800 & 2.13182300 \\ \text { H } & 0.96934300 & 4.78870700 & 2.06854300 \\ \text { S } & 5.15595400 & -0.64808700 & -0.06564900 \\ \text { O } & 5.57534800 & 0.37291000 & 0.94542100 \\ \text { O } & 5.50667600 & -2.04689300 & 0.33022900 \\ \text { O } & 5.59897300 & -0.29896900 & -1.452262000 \\ \text { S } & -5.16732100 & -0.61617400 & -0.064622000 \\ \text { O } & -5.53739400 & -1.01097600 & 1.33144600 \\ \text { O } & -5.60930800 & 0.76375500 & -0.426827000 \\ \text { O } & -5.55958300 & -1.64878200 & -1.07566000 \\ \text { H } & -2.88334600 & 1.51642100 & -0.63600800 \\ \text { H } & -2.81483400 & -2.69288000 & 0.45211000 \\ \text { H } & 2.78773500 & -2.71419500 & 0.44795700 \\ \text { H } & 2.88111300 & 1.49424100 & -0.63558400 \\ & & & \end{array}$

Sum of Electronic and Thermal Free Energies $=-2195.213403$ 


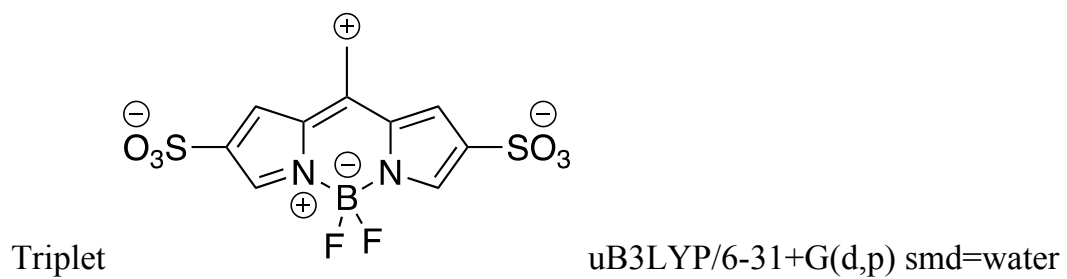

$\begin{array}{lrrr}\text { C } & -3.38440700 & 0.17914900 & -0.00234000 \\ \text { C } & -2.52452000 & -0.97238200 & 0.00514300 \\ \text { C } & -1.23029600 & 0.81727500 & -0.00092400 \\ \text { C } & 0.00001700 & 1.56228800 & 0.00022300 \\ \text { C } & 1.23030600 & 0.81722800 & 0.00122400 \\ \text { C } & -2.58543800 & 1.29187200 & -0.00598400 \\ \text { C } & 0.00005900 & 2.94339100 & 0.00036200 \\ \text { C } & 2.52448300 & -0.97245700 & -0.00517000 \\ \text { C } & 2.58547400 & 1.29178900 & 0.00630600 \\ \text { C } & 3.38439900 & 0.17903200 & 0.00251400 \\ \text { B } & -0.00002100 & -1.51561700 & 0.00025300 \\ \text { F } & -0.00493800 & -2.31000000 & -1.14515100 \\ \text { F } & 0.00489200 & -2.30937900 & 1.14611500 \\ \text { N } & 1.24454300 & -0.56940300 & -0.00480300 \\ \text { N } & -1.24458700 & -0.56939600 & 0.00481500 \\ \text { S } & 5.17114000 & 0.09906600 & 0.00009400 \\ \text { O } & 5.62947100 & 1.51155900 & 0.11881900 \\ \text { O } & 5.50983100 & -0.75037500 & 1.18098900 \\ \text { O } & 5.52114000 & -0.54166700 & -1.30317700 \\ \text { S } & -5.17114700 & 0.09905500 & -0.00047900 \\ \text { O } & -5.52168700 & -0.54265800 & 1.30218200 \\ \text { O } & -5.62948000 & 1.51164700 & -0.11835400 \\ \text { O } & -5.50922800 & -0.74952300 & -1.18213700 \\ \text { H } & -2.89376400 & 2.32664700 & -0.01295600 \\ \text { H } & -2.79482700 & -2.02061400 & 0.00873000 \\ \text { H } & 2.79468100 & -2.02071800 & -0.00881100 \\ \text { H } & 2.89385700 & 2.32654500 & 0.01329500 \\ \text { H } & 0.92726900 & 3.50363200 & 0.00180000 \\ \text { H } & -0.92711200 & 3.50370000 & -0.00062900\end{array}$

Sum of Electronic and Thermal Free Energies $=-1966.568086$ 


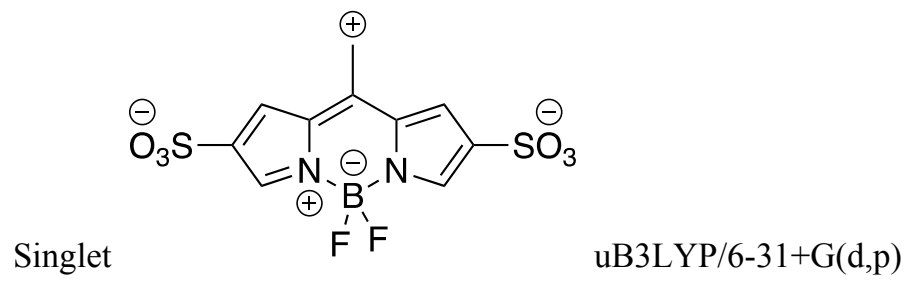

$\begin{array}{lrrr}\mathrm{C} & 3.38466000 & 0.19179300 & 0.04455500 \\ \mathrm{C} & 2.51536000 & -0.95777800 & 0.01520800 \\ \mathrm{C} & 1.25022600 & 0.84452100 & -0.18170900 \\ \mathrm{C} & 0.00000000 & 1.58272700 & -0.28892000 \\ \mathrm{C} & -1.25022600 & 0.84452100 & -0.18170900 \\ \mathrm{C} & 2.57707700 & 1.30926600 & -0.08433700 \\ \mathrm{C} & 0.00000000 & 2.93153200 & -0.46813500 \\ \mathrm{C} & -2.51536000 & -0.95777800 & 0.01520800 \\ \mathrm{C} & -2.57707700 & 1.30926600 & -0.08433700 \\ \mathrm{C} & -3.38466000 & 0.19179300 & 0.04455500 \\ \mathrm{~B} & 0.00000000 & -1.48880300 & -0.30452500 \\ \mathrm{~F} & 0.00000000 & -2.48367800 & 0.65780300 \\ \mathrm{~F} & 0.00000000 & -2.01128700 & -1.59162500 \\ \mathrm{~N} & -1.24694800 & -0.55324100 & -0.11642300 \\ \mathrm{~N} & 1.24694800 & -0.55324100 & -0.11642300 \\ \mathrm{~S} & -5.15610500 & 0.08277700 & 0.22588000 \\ \mathrm{O} & -5.63400800 & 1.48129900 & 0.20281900 \\ \mathrm{O} & -5.52968700 & -0.75080900 & -0.95391500 \\ \mathrm{O} & -5.29199800 & -0.62946800 & 1.52873700 \\ \mathrm{~S} & 5.15610500 & 0.08277700 & 0.22588000 \\ \mathrm{O} & 5.52968700 & -0.75080900 & -0.95391600 \\ \mathrm{O} & 5.63400800 & 1.48129900 & 0.20281900 \\ \mathrm{O} & 5.29199800 & -0.62946800 & 1.52873800 \\ \mathrm{H} & 2.92147500 & 2.33233000 & -0.08157200 \\ \mathrm{H} & 2.78557100 & -2.00250000 & 0.08116900 \\ \mathrm{H} & -2.78557100 & -2.00250000 & 0.08116900 \\ \mathrm{H} & -2.92147500 & 2.33233000 & -0.08157200 \\ \mathrm{H} & -0.92486500 & 3.48999300 & -0.54748700 \\ \mathrm{H} & 0.92486500 & 3.48999300 & -0.54748700\end{array}$

Uncorrected Sum of Electronic and Thermal Free Energies $=-1966.437785$

Corrected Sum of Electronic and Thermal Free Energies $=-1966.437785$ 


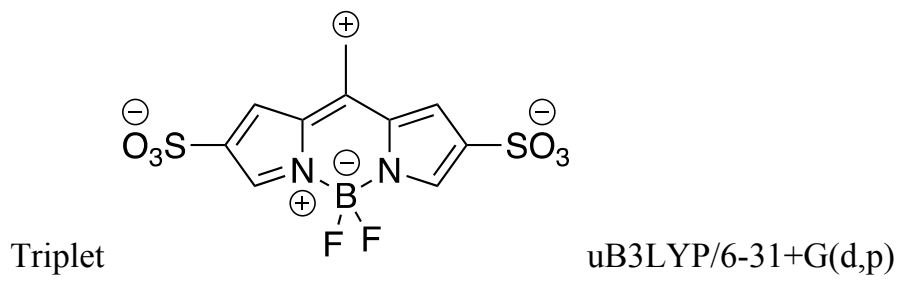

$\begin{array}{lrrr}\text { C } & 3.38786400 & 0.19487100 & 0.02345600 \\ \mathrm{C} & 2.51837300 & -0.95593200 & 0.01602600 \\ \mathrm{C} & 1.24023900 & 0.84310800 & -0.10954600 \\ \mathrm{C} & 0.00000000 & 1.57585700 & -0.16675000 \\ \mathrm{C} & -1.24023900 & 0.84310800 & -0.10954600 \\ \mathrm{C} & 2.57525100 & 1.30862400 & -0.05920300 \\ \mathrm{C} & 0.00000000 & 2.95392500 & -0.25802200 \\ \mathrm{C} & -2.51837300 & -0.95593200 & 0.01602600 \\ \mathrm{C} & -2.57525100 & 1.30862400 & -0.05920300 \\ \mathrm{C} & -3.38786400 & 0.19487000 & 0.02345700 \\ \mathrm{~B} & 0.00000000 & -1.50738000 & -0.17435200 \\ \mathrm{~F} & 0.00000000 & -2.42047200 & 0.86641300 \\ \mathrm{~F} & 0.00000000 & -2.13461700 & -1.41220200 \\ \mathrm{~N} & -1.24705600 & -0.55927600 & -0.06113300 \\ \mathrm{~N} & 1.24705600 & -0.55927600 & -0.06113300 \\ \mathrm{~S} & -5.16930900 & 0.08773400 & 0.12974800 \\ \mathrm{O} & -5.63663800 & 1.49013200 & 0.10141900 \\ \mathrm{O} & -5.49702500 & -0.73121500 & -1.07184300 \\ \mathrm{O} & -5.35662600 & -0.63419200 & 1.42005300 \\ \mathrm{~S} & 5.16930900 & 0.08773400 & 0.12974800 \\ \mathrm{O} & 5.49702600 & -0.73121500 & -1.07184300 \\ \mathrm{O} & 5.63663800 & 1.49013200 & 0.10142000 \\ \mathrm{O} & 5.35662500 & -0.63419200 & 1.42005300 \\ \mathrm{H} & 2.91835100 & 2.33212500 & -0.06647400 \\ \mathrm{H} & 2.79587800 & -2.00024000 & 0.06085800 \\ \mathrm{H} & -2.79587800 & -2.00024100 & 0.06085800 \\ \mathrm{H} & -2.91835100 & 2.33212500 & -0.06647300 \\ \mathrm{H} & -0.92550000 & 3.51447900 & -0.29760900 \\ \mathrm{H} & 0.92550000 & 3.51447900 & -0.29761000\end{array}$

Sum of Electronic and Thermal Free Energies $=-1966.444439$ 


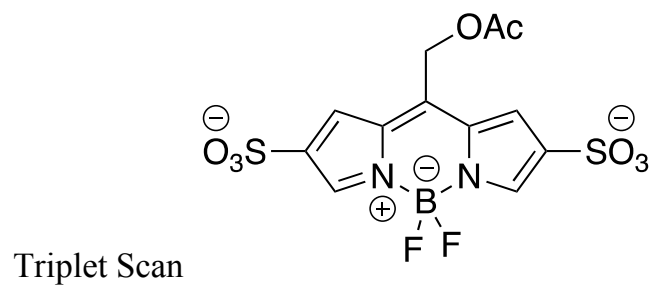

uB3LYP/6-31+G(d,p) smd=water (Reactant)

$\begin{array}{lrrr}\text { C } & -3.38441500 & -0.57062200 & -0.09469400 \\ \mathrm{C} & -2.54684400 & -1.68023200 & 0.18456900 \\ \mathrm{C} & -1.21548100 & 0.04760800 & -0.28037400 \\ \mathrm{C} & -0.00055100 & 0.74661000 & -0.48486300 \\ \mathrm{C} & 1.20539500 & 0.03728900 & -0.28250500 \\ \mathrm{C} & -2.57781600 & 0.51240400 & -0.38284600 \\ \mathrm{C} & 0.00567000 & 2.18657100 & -0.86936700 \\ \mathrm{H} & -0.88151100 & 2.45767400 & -1.44351800 \\ \mathrm{O} & 0.01575500 & 2.99699900 & 0.35997000 \\ \mathrm{H} & 0.89075700 & 2.44785000 & -1.45119300 \\ \mathrm{C} & 2.52585000 & -1.70053200 & 0.18101600 \\ \mathrm{C} & 2.57162800 & 0.49033500 & -0.38392900 \\ \mathrm{C} & 3.37113800 & -0.60252000 & -0.09523400 \\ \mathrm{~B} & -0.01222800 & -2.19677700 & 0.29857900 \\ \mathrm{~F} & -0.02028600 & -3.28318900 & -0.60249700 \\ \mathrm{~F} & -0.01411300 & -2.71410200 & 1.61167200 \\ \mathrm{~N} & 1.22363400 & -1.30210000 & 0.06668500 \\ \mathrm{~N} & -1.24335000 & -1.29085200 & 0.07009800 \\ \mathrm{C} & 0.03494200 & 4.33505900 & 0.20588900 \\ \mathrm{O} & 0.03755800 & 4.87585200 & -0.89505700 \\ \mathrm{C} & 0.05811900 & 5.05375600 & 1.52265100 \\ \mathrm{H} & 0.02781500 & 6.13066300 & 1.35728900 \\ \mathrm{H} & -0.79647300 & 4.74434800 & 2.13182300 \\ \mathrm{H} & 0.96934300 & 4.78870700 & 2.06854300 \\ \mathrm{~S} & 5.15595400 & -0.64808700 & -0.06564900 \\ \mathrm{O} & 5.57534800 & 0.37291000 & 0.94542100 \\ \mathrm{O} & 5.50667600 & -2.04689300 & 0.33022900 \\ \mathrm{O} & 5.59897300 & -0.29896900 & -1.45226200 \\ \mathrm{~S} & -5.16732100 & -0.61617400 & -0.06462200 \\ \mathrm{O} & -5.53739400 & -1.01097600 & 1.33144600 \\ \mathrm{O} & -5.60930800 & 0.76375500 & -0.42682700 \\ \mathrm{O} & -5.55958300 & -1.64878200 & -1.07566000 \\ \mathrm{H} & -2.88334600 & 1.51642100 & -0.63600800 \\ \mathrm{H} & -2.81483400 & -2.69288000 & 0.45211000 \\ \mathrm{H} & 2.78773500 & -2.71419500 & 0.44795700 \\ \mathrm{H} & 2.88111300 & 1.49424100 & -0.63558400\end{array}$

SCF Energy $=-2195.37531762$ 


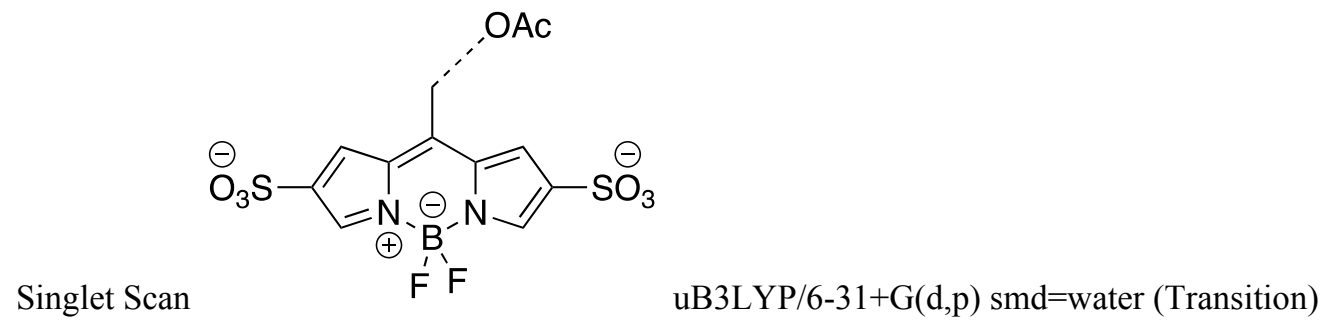

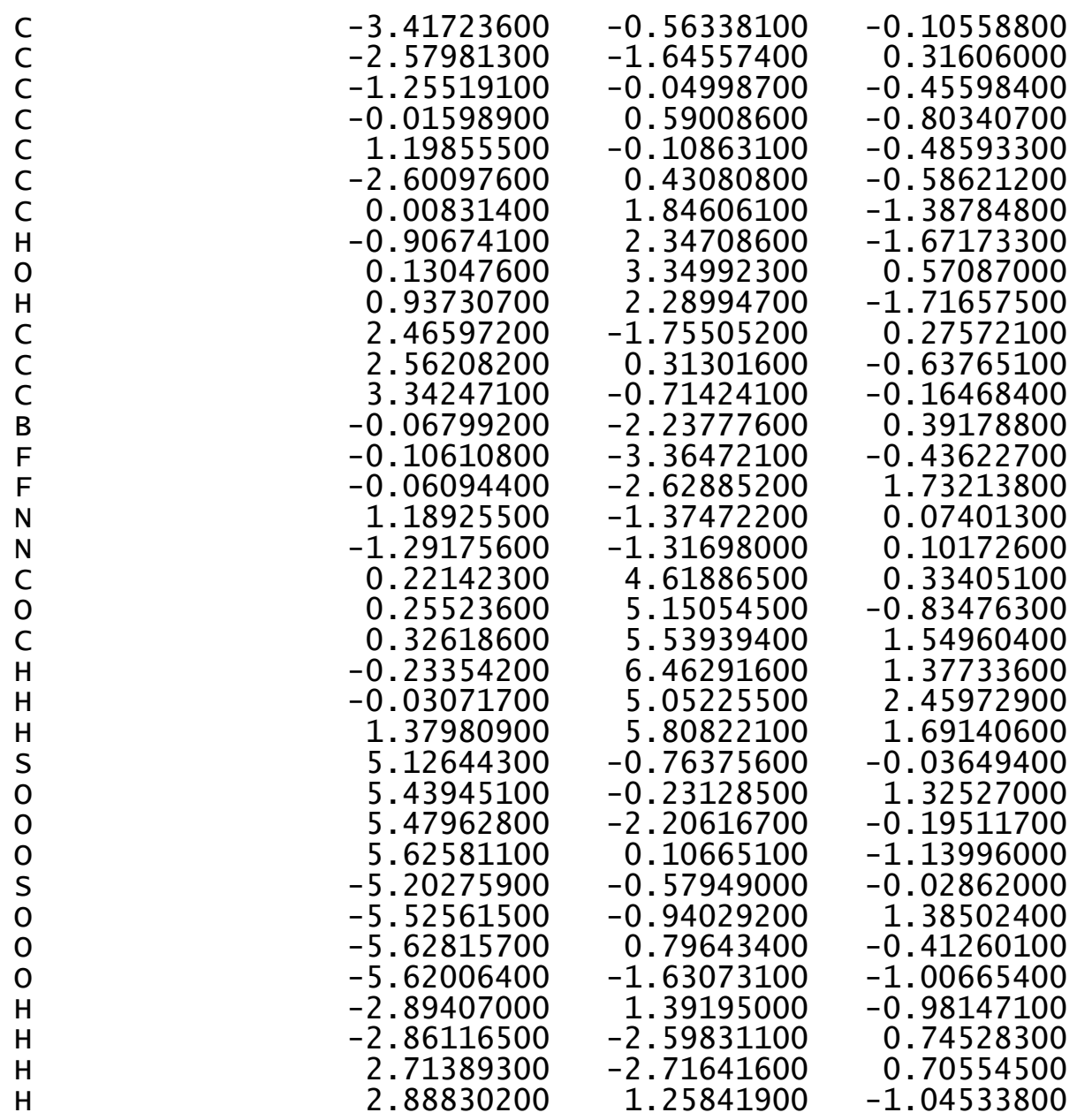

SCF Energy = -2195.34524488 
<smiles></smiles>

Triplet F ' $F$
uB3LYP/6-31+G(d,p) smd=water

$\begin{array}{lrrr}\text { C } & -3.39041200 & -0.86652600 & -0.09040000 \\ \mathrm{C} & -2.53204600 & -1.96055200 & 0.17348200 \\ \mathrm{C} & -1.21103400 & -0.22469300 & -0.28151700 \\ \mathrm{C} & -0.00004800 & 0.47853600 & -0.48075600 \\ \mathrm{C} & 1.21197800 & -0.22283400 & -0.28132300 \\ \mathrm{C} & -2.57535500 & 0.23214100 & -0.37572700 \\ \mathrm{C} & -0.00116600 & 1.92130600 & -0.86080800 \\ \mathrm{H} & -0.88735900 & 2.18619800 & -1.43935300 \\ \mathrm{O} & -0.00274600 & 2.72262200 & 0.37086600 \\ \mathrm{H} & 0.88524600 & 2.18784200 & -1.43825200 \\ \mathrm{C} & 2.53555500 & -1.95672900 & 0.17378400 \\ \mathrm{C} & 2.57562600 & 0.23601900 & -0.37544800 \\ \mathrm{C} & 3.39230300 & -0.86143800 & -0.09007600 \\ \mathrm{~B} & 0.00214200 & -2.47360900 & 0.27723300 \\ \mathrm{~F} & 0.00307800 & -3.53889300 & -0.64237500 \\ \mathrm{~F} & 0.00238000 & -3.00094800 & 1.58146900 \\ \mathrm{~N} & 1.23771300 & -1.56588500 & 0.05910100 \\ \mathrm{~N} & -1.23477800 & -1.56778500 & 0.05885700 \\ \mathrm{C} & -0.00416500 & 4.06275800 & 0.22220400 \\ \mathrm{O} & -0.00375000 & 4.60633300 & -0.87677100 \\ \mathrm{C} & -0.00622000 & 4.77544800 & 1.54200000 \\ \mathrm{H} & 0.87679000 & 4.48567000 & 2.12006300 \\ \mathrm{H} & -0.00626500 & 5.85326900 & 1.38016700 \\ \mathrm{H} & -0.89090100 & 4.48527800 & 2.11733000 \\ \mathrm{C} & 4.84468300 & -0.93546300 & -0.04884500 \\ \mathrm{O} & 5.59161100 & 0.01952200 & -0.27885100 \\ \mathrm{H} & 5.26578400 & -1.92218700 & 0.20728200 \\ \mathrm{C} & -4.84268300 & -0.94270300 & -0.04920300 \\ \mathrm{O} & -5.59103300 & 0.01117000 & -0.27919000 \\ \mathrm{H} & -5.26230200 & -1.93008100 & 0.20685800 \\ \mathrm{H} & -2.88501600 & 1.23787500 & -0.61958100 \\ \mathrm{H} & -2.79183500 & -2.97838300 & 0.43406300 \\ \mathrm{H} & 2.88386200 & 1.24219300 & -0.61929500 \\ \mathrm{H} & 2.79685700 & -2.97417400 & 0.43435600 \\ & & & \end{array}$

Sum of Electronic and Thermal Free Energies $=-1175.073622$ 
<smiles></smiles>

$\begin{array}{lrrr}\text { C } & 3.39648400 & 0.09480700 & 0.00008100 \\ \text { C } & 2.52778600 & -1.04708900 & -0.00001300 \\ \text { C } & 1.22972500 & 0.73772000 & -0.00035900 \\ \text { C } & 0.00000000 & 1.48509800 & -0.00036900 \\ \text { C } & -1.22972500 & 0.73772000 & -0.00035800 \\ \text { C } & 2.58799200 & 1.21159400 & -0.00019100 \\ \text { C } & 0.00000000 & 2.86543600 & -0.00025800 \\ \text { H } & 0.92747500 & 3.42543500 & -0.00024500 \\ \text { H } & -0.92747400 & 3.42543500 & -0.00024500 \\ \text { C } & -2.52778600 & -1.04708900 & -0.00001200 \\ \text { C } & -2.58799200 & 1.21159400 & -0.00019000 \\ \text { C } & -3.39648400 & 0.09480700 & 0.00008300 \\ \text { B } & 0.00000000 & -1.59232700 & -0.00017200 \\ \text { F } & 0.00000000 & -2.38340200 & 1.14598600 \\ \text { F } & 0.00000000 & -2.38367100 & -1.14611000 \\ \text { N } & -1.24489600 & -0.64467400 & -0.00026100 \\ \text { N } & 1.24489600 & -0.64467400 & -0.00026200 \\ \text { C } & -4.86303400 & 0.02569200 & 0.00047800 \\ \text { O } & -5.58049000 & 1.02104100 & 0.00055600 \\ \text { H } & -5.29658400 & -0.98720200 & 0.00073100 \\ \text { C } & 4.86303400 & 0.02569200 & 0.00047600 \\ \text { O } & 5.58049000 & 1.02104100 & 0.00055900 \\ \text { H } & 5.29658400 & -0.98720200 & 0.00073300 \\ \text { H } & 2.89529500 & 2.24738800 & -0.00032800 \\ \text { H } & 2.79592500 & -2.09652200 & 0.00009700 \\ \text { H } & -2.89529500 & 2.24738800 & -0.00032600 \\ \text { H } & -2.79592500 & -2.09652200 & 0.00009800\end{array}$

Sum of Electronic and Thermal Free Energies = -946.419947 
<smiles></smiles>

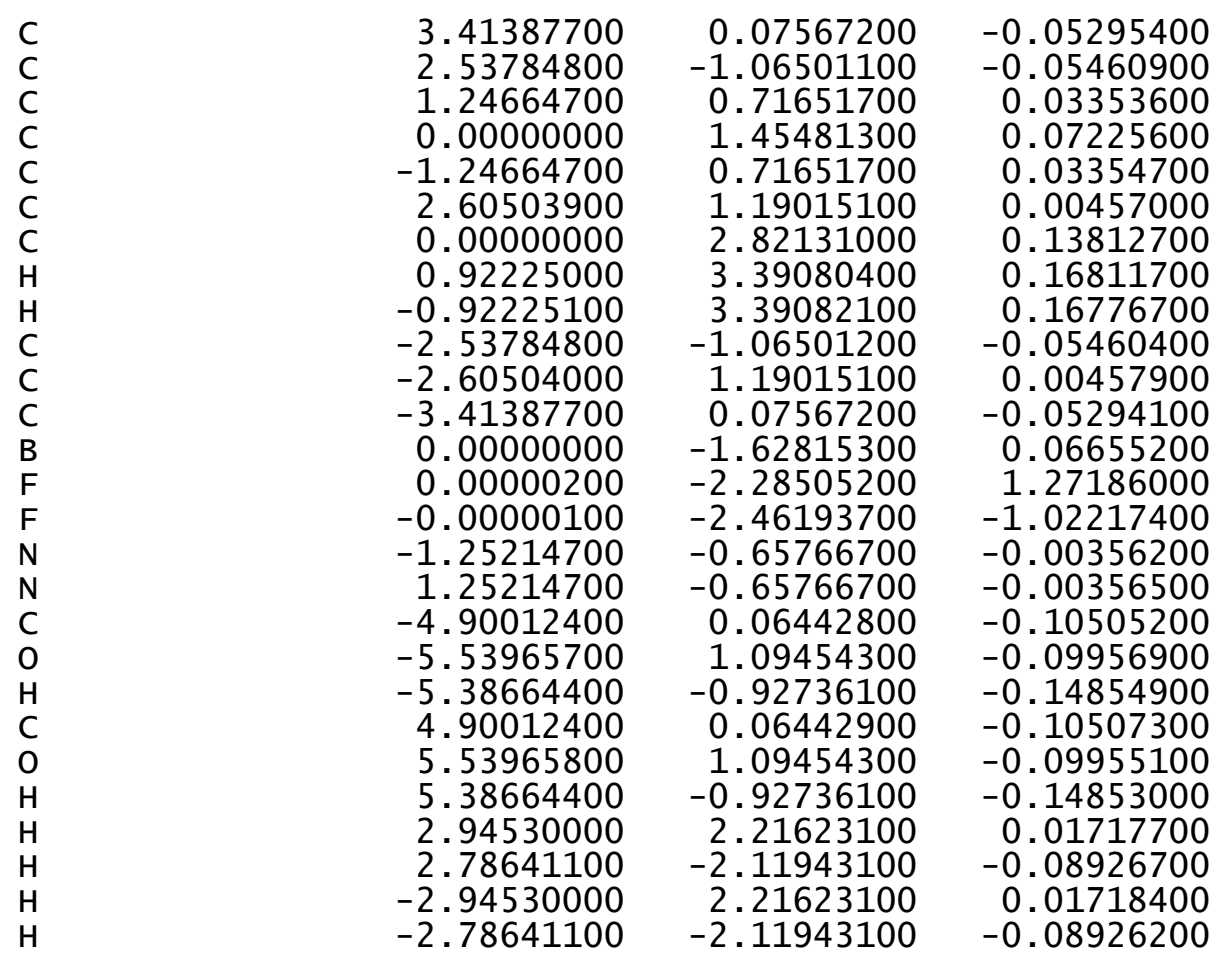

Uncorrected Sum of Electronic and Thermal Free Energies $=-946.306880$

Corrected Sum of Electronic and Thermal Free Energies $=-946.305635$ 


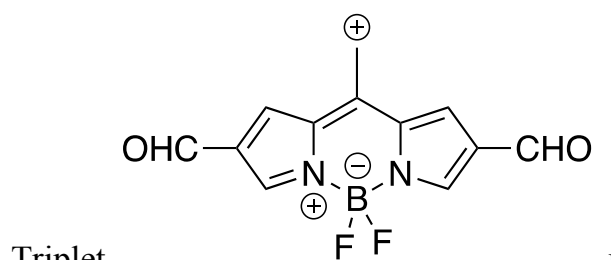

Triplet $\quad$ F F uB3LYP/6-31+G(d,p)

$\begin{array}{lrrr}\text { C } & 3.40200100 & 0.08048700 & -0.07973900 \\ \text { C } & 2.52326400 & -1.06787700 & -0.07912200 \\ \text { C } & 1.23637300 & 0.71686900 & 0.05205100 \\ \text { C } & 0.00000000 & 1.45833200 & 0.11364000 \\ \text { C } & -1.23637300 & 0.71686900 & 0.05205500 \\ \text { C } & 2.59317000 & 1.19015500 & 0.00523500 \\ \text { C } & 0.00000000 & 2.83767100 & 0.21380300 \\ \text { H } & 0.92256200 & 3.40371900 & 0.25844900 \\ \text { H } & -0.92256200 & 3.40371900 & 0.25845200 \\ \text { C } & -2.52326400 & -1.06787700 & -0.07911500 \\ \text { C } & -2.59317000 & 1.19015500 & 0.00524300 \\ \text { C } & -3.40200200 & 0.08048700 & -0.07972900 \\ \text { B } & 0.00000000 & -1.63878200 & 0.10024100 \\ \text { F } & 0.00000200 & -2.25235100 & 1.32812500 \\ \text { F } & -0.00000100 & -2.50899000 & -0.95900600 \\ \text { N } & -1.24778900 & -0.66835400 & -0.00258800 \\ \text { N } & 1.24778900 & -0.66835400 & -0.00259100 \\ \mathrm{C} & -4.88752600 & 0.06939100 & -0.16005000 \\ \text { O } & -5.52605000 & 1.10005800 & -0.15403800 \\ \text { H } & -5.37349300 & -0.92139300 & -0.22486300 \\ \text { C } & 4.88752500 & 0.06939100 & -0.16006500 \\ \text { O } & 5.52605100 & 1.10005700 & -0.15401900 \\ \text { H } & 5.37349400 & -0.92139400 & -0.22484800 \\ \text { H } & 2.92976700 & 2.21724600 & 0.02133300 \\ \text { H } & 2.77704400 & -2.12073000 & -0.12884100 \\ \text { H } & -2.92976800 & 2.21724600 & 0.02134200 \\ \text { H } & -2.77704500 & -2.12073000 & -0.12883300\end{array}$

Sum of Electronic and Thermal Free Energies $=-946.311270$ 
<smiles>CC(=O)OCC1=C2C=C(C=O)C=[N+]2[B-](F)(F)n2cc(C=O)cc21</smiles>
Triplet Scan
uB3LYP/6-31+G(d,p) smd=water (Reactant)

\begin{tabular}{lr}
$\mathrm{C}$ & -3.39041200 \\
$\mathrm{C}$ & -2.53204600 \\
$\mathrm{C}$ & -1.21103400 \\
$\mathrm{C}$ & -0.00004800 \\
$\mathrm{C}$ & 1.21197800 \\
$\mathrm{C}$ & -2.57535500 \\
$\mathrm{C}$ & -0.00116600 \\
$\mathrm{H}$ & -0.88735900 \\
$\mathrm{O}$ & -0.00274600 \\
$\mathrm{H}$ & 0.88524600 \\
$\mathrm{C}$ & 2.53555500 \\
$\mathrm{C}$ & 2.57562600 \\
$\mathrm{C}$ & 3.39230300 \\
$\mathrm{~B}$ & 0.00214200 \\
$\mathrm{~F}$ & 0.00307800 \\
$\mathrm{~F}$ & 0.00238000 \\
$\mathrm{~N}$ & 1.23771300 \\
$\mathrm{~N}$ & -1.23477800 \\
$\mathrm{C}$ & -0.00416500 \\
$\mathrm{O}$ & -0.00375000 \\
$\mathrm{C}$ & -0.00622000 \\
$\mathrm{H}$ & 0.87679000 \\
$\mathrm{H}$ & -0.00626500 \\
$\mathrm{H}$ & -0.89090100 \\
$\mathrm{C}$ & 4.84468300 \\
$\mathrm{O}$ & 5.59161100 \\
$\mathrm{H}$ & 5.26578400 \\
$\mathrm{C}$ & -4.84268300 \\
$\mathrm{O}$ & -5.59103300 \\
$\mathrm{H}$ & -5.26230200 \\
$\mathrm{H}$ & -2.88501600 \\
$\mathrm{H}$ & -2.79183500 \\
$\mathrm{H}$ & 2.88386200 \\
$\mathrm{H}$ & 2.79685700 \\
& \\
\hline & \\
\hline &
\end{tabular}

SCF Energy = -1175.25673511
$-0.86652600$

$-1.96055200$

$-0.22469300$

0.47853600

$-0.22283400$

0.23214100

1.92130600

2. 18619800

2.72262200

2.18784200

$-1.95672900$

0.23601900

$-0.86143800$

$-2.47360900$

$-3.53889300$

$-3.00094800$

$-1.56588500$

$-1.56778500$

4.06275800

4.60633300

4.77544800

4.48567000

5.85326900

4.48527800

$-0.93546300$

0.01952200

$-1.92218700$

$-0.94270300$

0.01117000

$-1.93008100$

1. 23787500

$-2.97838300$

1.24219300

$-2.97417400$
$-0.09040000$

0.17348200

$-0.28151700$

$-0.48075600$

$-0.28132300$

$-0.37572700$

$-0.86080800$

$-1.43935300$

0.37086600

$-1.43825200$

0.17378400

$-0.37544800$

$-0.09007600$

0.27723300

$-0.64237500$

1. 58146900

0.05910100

0.05885700

0.22220400

$-0.87677100$

1. 54200000

2. 12006300

1. 38016700

2. 11733000

$-0.04884500$

$-0.27885100$

0.20728200

$-0.04920300$

$-0.27919000$

0.20685800

$-0.61958100$

0.43406300

$-0.61929500$

0.43435600 


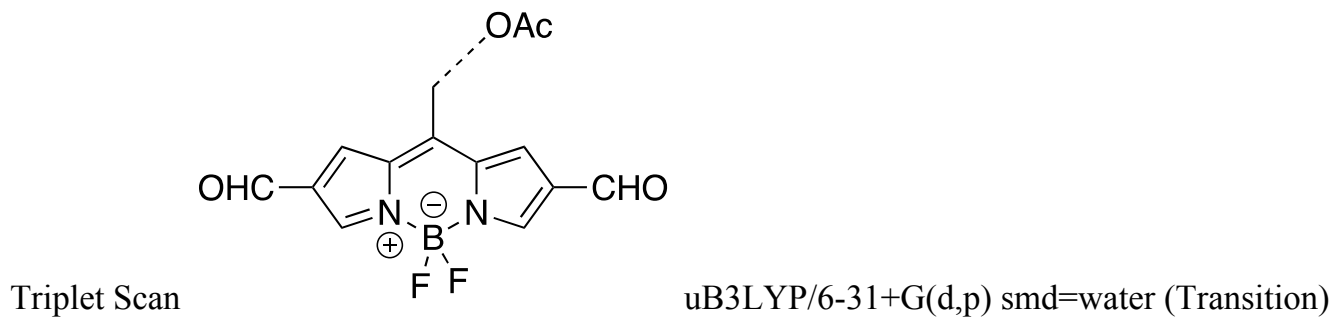

$\begin{array}{lrrr}\text { C } & -3.50358100 & -0.61026300 & -0.15429200 \\ \text { C } & -2.75144300 & -1.69583100 & 0.40299800 \\ \text { C } & -1.29008600 & -0.31675300 & -0.51278100 \\ \text { C } & 0.00262000 & 0.18003300 & -0.90131400 \\ \text { C } & 1.15220600 & -0.59939600 & -0.52589300 \\ \text { C } & -2.59294900 & 0.25410600 & -0.72669100 \\ \text { C } & 0.13613300 & 1.36637200 & -1.59550900 \\ \text { H } & -0.72873400 & 1.94650600 & -1.89097400 \\ \text { O } & 0.34416200 & 3.34214300 & 0.74420400 \\ \text { H } & 1.10978200 & 1.73735300 & -1.88921300 \\ \text { C } & 2.26962700 & -2.27681000 & 0.37586100 \\ \text { C } & 2.54898400 & -0.33865700 & -0.75092400 \\ \text { C } & 3.24405100 & -1.38776500 & -0.18500900 \\ \text { B } & -0.29675300 & -2.47226500 & 0.62832200 \\ \text { F } & -0.44516000 & -3.71060600 & 0.00667200 \\ \text { F } & -0.30524800 & -2.61495700 & 2.01401300 \\ \text { N } & 1.03255900 & -1.79173000 & 0.16338600 \\ \text { N } & -1.43868000 & -1.50352200 & 0.18027700 \\ \text { C } & 0.55860300 & 4.56607700 & 0.46373900 \\ \text { O } & 0.57394100 & 5.03995500 & -0.71647800 \\ \text { C } & 0.85100600 & 5.51554900 & 1.62242600 \\ \text { H } & 1.93069900 & 5.50453800 & 1.81611500 \\ \text { H } & 0.56301100 & 6.54061900 & 1.37606500 \\ \text { H } & 0.34323500 & 5.19542100 & 2.53579300 \\ \text { C } & 4.69463900 & -1.60172100 & -0.13017300 \\ \text { O } & 5.50798800 & -0.82548500 & -0.62258200 \\ \text { H } & 5.02548300 & -2.51593200 & 0.38885400 \\ \text { C } & -4.96544200 & -0.49629700 & -0.100853000 \\ \text { O } & -5.58507400 & 0.44147600 & -0.59400900 \\ \text { H } & -5.49177200 & -1.31536800 & 0.415165000 \\ \text { H } & -2.80038400 & 1.18221700 & -1.239931000 \\ \text { H } & -3.11707000 & -2.56673500 & 0.93314800 \\ \text { H } & 2.95883100 & 0.52094100 & -1.26158000 \\ \text { H } & 2.43285500 & -3.20797200 & 0.90454400 \\ & & & \end{array}$

SCF Energy $=-1175.22001504$ 


\section{References}

1. E. Stadler, A. Eibet, D. Fast, H. Freißmuth, C. Holly, M. Wiech, N. Moszner, G. Gescheidt Photochem. Photobiol. Sci., 2018, 17, 660

2. T. Slanina, P. Shrestha, E. Palao, D. Kand, J. A. Peterson, A. S. Dutton, N. Rubinstein, R. Weinstain, A. H. Winter, P. Klán J. Am. Chem. Soc., 2017, 139(42), 15168

3. N. Rubinstein, P. Liu, E. W. Miller, R. Weinstain Chem. Commun., 2015, 51, 6369.

4. M. J.Frisch, G. W.Trucks, H. B.Schlegel, G. E.Scuseria, M. A.Robb, J. R.Cheeseman, G.Scalmani, V.Barone, B.Mennucci, G. A.Petersson, H.Nakatsuji, M.Caricato, X.Li, P. H.Hratchian, A. F.Izmaylov, J.Bloino, G.Zheng, J. L.Sonnenberg, M.Hada, M.Ehara, K.Toyota, R.Fukuda, J.Hasegawa, M.Ishida, T.Nakajima, Y.Honda, O.Kitao, H.Nakai, T.Vreven, J. A.Montgomery JrJ. E.Peralta, F.Ogliaro, M.Bearpark, J.Heyd, E.Brothers, K. N.Kudin, V. N.Staroverov, R.Kobayashi, J.Normand, K.Raghavachari, A.Rendell, J. C.Burant, S. S.Iyengar, J.Tomasi, M.Cossi, N.Rega, J. M.Millam, M.Klene, J. E.Knox, J. B.Cross, V.Bakken, C.Adamo, J.Jaramillo, R.Gomperts, R. E.Stratmann, O.Yazyev, A. J.Austin, R.Cammi, C.Pomelli, J. W.Ochterski, R. L.Martin, K.Morokuma, V. G.Zakrzewski, G. A.Voth, P.Salvador, J. J.Dannenberg, S.Dapprich, A. D.Daniels, O.Farkas, J. B.Foresman, J. V.Ortiz, J.Cioslowski and D. J.Fox, Gaussian 09, Gaussian, Inc., Wallingford, CT, 2009.

5. C. Lee, W. Yang and R. G. Parr, Phys. Rev. B: Condens. Matter Mater. Phys., 1988, 37, 785

6. A. D. Becke J. Chem. Phys., 1993, 98, 5648

7. P. J. Stephens, F. J. Deblin, C. F. Chabalowski and M. J. Frisch, J. Phys. Chem., 1994, 98,1162

8. A. V. Marenich, C. J. Cramer, and D. G. Truhlar, J. Phys. Chem. B, 2009, 113, 6378

9. H. Isobe, Y. Takano, Y. Kitagawa, T. Kawakami, S. Yamanaka, K. Yamaguchi and K. N. Houk, Mol. Phys., 2002, 100,717

10. K. Yamaguchi, F. Jensen, A. Dorigo and K. N. Houk, Chem. Phys. Lett., 1988, 149, 537

11. M. H. Lim, S. E. Worthington, D. J. Frederic and C. J. Cramer, ACS Symp. Ser., 1996, 629, 402

12. L. Noodleman and D. A. Case, Adv. Inorg. Chem., 1992, 38, 423

13. H. Hansch, A. Leo and D. Hoekman, Exploring QSAR: Hydrophobic, Electronic, and Steric Constants, American Chemical Society, Washington DC, 1995, vol. Vol. 2 